\title{
Prognostic factors in primary breast cancer
}

Citation for published version (APA):

Jansen, R. L. H. (1998). Prognostic factors in primary breast cancer. [Doctoral Thesis, Maastricht University]. Universiteit Maastricht. https://doi.org/10.26481/dis.19981001rj

Document status and date:

Published: 01/01/1998

DOI:

10.26481/dis.19981001rj

Document Version:

Publisher's PDF, also known as Version of record

\section{Please check the document version of this publication:}

- A submitted manuscript is the version of the article upon submission and before peer-review. There can be important differences between the submitted version and the official published version of record.

People interested in the research are advised to contact the author for the final version of the publication, or visit the DOI to the publisher's website.

- The final author version and the galley proof are versions of the publication after peer review.

- The final published version features the final layout of the paper including the volume, issue and page numbers.

Link to publication

\footnotetext{
General rights rights.

- You may freely distribute the URL identifying the publication in the public portal. please follow below link for the End User Agreement:

www.umlib.nl/taverne-license

Take down policy

If you believe that this document breaches copyright please contact us at:

repository@maastrichtuniversity.nl

providing details and we will investigate your claim.
}

Copyright and moral rights for the publications made accessible in the public portal are retained by the authors and/or other copyright owners and it is a condition of accessing publications that users recognise and abide by the legal requirements associated with these

- Users may download and print one copy of any publication from the public portal for the purpose of private study or research.

- You may not further distribute the material or use it for any profit-making activity or commercial gain

If the publication is distributed under the terms of Article $25 \mathrm{fa}$ of the Dutch Copyright Act, indicated by the "Taverne" license above, 


\section{Prognostic Factors in Primary Breast Cancer}


de Rob Jansen

ISBN 90-901 1977-9

Printing of this thesis was made possible by gifts of Schering-Plough, Zeneca, Asta Medica, and Bristol-Myers Squibb. 


\title{
Prognostic Factors in Primary Breast Cancer
}

\author{
PROEFSCHRIFT
}

ter verkrijging van de graad van doctor aan de Universiteit Maastricht, op gezag van de Rector Magnificus,

Prof. Dr. A.C. Nieuwenhuijzen Kruseman, volgens het besluit van het College van Decanen, in het openbaar te verdedigen op donderdag 1 oktober 1998 om 14.00 uur

door

R L H Jansen

geboren op 30-05-1.954 te Breda 


\section{Promotores}

Prof ar HFP Hillen

Prof $\mathrm{dr} J$-W Arends

\section{Co-promotor}

Dr HC Schouten

\section{Beoordelingscommissie}

Prof dr MF von Meyenfeldt (voorzitter)

Prof dr GH Blijham (Universiteit Utrecht)

Prof dr ir PA van den Brandt

Dr JGM Klijn (Erasmus Universiteit Rotterdam)

Prof dr FCS Ramaekers 
Aan: Carla, Mark, Lenno en Rodi 



\section{Contents}

Chapter IA Prognostic and predictive factors in breast cancer 9

Chapter IB This thesis $\mathbf{3 3}$

Chapter II $\quad \mathrm{pS} 2$ is an independent prognostic factor for post-relapse survival in primary breast cancer $\mathbf{3 7}$

Chapter III CD44v6 is not a prognostic factor in primary breast cancer 51

Chapter IV MIB-1 labelling index is an independent prognostic marker in primary breast cancer $\mathbf{5 9}$

Chapter $\mathrm{V} \quad$ Relevance of the expression of bcl-2 in combination with p53 as a prognostic factor in breast cancer 75

Chapter VI Microvessel density is correlated with age, but not with prognosis in breast cancer $\mathbf{9 3}$

Chapter VII Summary and general discussion 107

Chapter VIII Samenvatting en algemene discussie 115

Dankwoord 123

Curriculum vitae 127 



\section{Chapter IA}

\section{Prognostic and predictive factors in breast cancer}

RLH Jansen, HFP Hillen, HC Schouten

Netherlands Joumal of Medicine 1997; 51: 65-77 


\section{Introduction}

Breast cancer is the most frequent cancer type in Dutch women and accounts for $22 \%$ of all cancer deaths. To date the axillary lymph node status is the most important prognostic tactor for patients with breast cancer. In general, the l0-year survival of node-negative patients is about $70 \%$ whereas the 10-year survival in node-positive patients is only about $30 \%^{2}$, whereby the prognosis is directly related to the number of involved axillary nodes ${ }^{2}$. Traditionally the axillary lymph node status has guided the need for adjuvant therapy. However, in terms of the absolute effect on mortality after 10 years less than $10 \%$ of the patients benefit from adjuvant treatment ${ }^{3.4}$. There is a need to prognosticate which patients with nodepositive disease will not benefit from standard adjuvant treatment or will be cured without it. In node-negative patients we need more information on which patients should be treated with adjuvant therapy to improve survival. Therefore, there is an urgent need for prognostic factors derived from the primary tumour to make better patient selection. So far, numerous prognostic factors have been investigated. To be useful in clinical practice a prognostic factor should have a good prognostic value, should be cheap and easy to perform. Here we shall briefly review the most important prognostic and predictive factors. A prognostic factor is a factor associated with disease-free or overall survival in the absence of systemic adjuvant therapy. A predictive factor is defined as a factor associated with response to a particular therapy.

\section{Primary treatment}

Treatment of the primary tumour with either mastectomy, lumpectomy with radiation therapy or lumpectomy without radiation therapy does not influence overall survival ${ }^{5,6}$. Lumpectomy without radiation therapy, however, greatly increases the risk of local recurrence ${ }^{5,6}$. Although the axillary lymph node status is the most important prognostic factor, the influence of the routine axillary nodal dissection itself on overall survival has especially recently become a matter for discussion ${ }^{7.8}$. Such an influence is at best very limited, whereby it has to be kept in mind that an axillary lymph node dissection can cause substantial morbidity.

Remarkably, a recent study demonstrated that the surgeon per se can be a prognostic factor: care by a specialist surgeon resulted in a $8 \%$ improvement in 10 year survival compared with a non-specialist surgeon". 


\section{Patient characteristics}

Studies on the influence of age on the clinical outcome of breast cancer have been controversial. However, most studies have found a worse clinical outcome in younger patients ${ }^{10-15}$. Despite a high correlation of younger age with poor prognostic factors like S-phase fraction and p53 abnormalities in two of these studies age younger than 35 years was in multivariate analyses still a poor prognostic factor ${ }^{14,15}$. Based on these studies and a more recently published study of 3722 patients $^{16}$ it seems reasonable to conclude that women younger than $35-40$ years have a worse prognosis.

In breast cancer black women have a higher mortality rate than white women ${ }^{17,18}$. This is because black women have tumours that are more advanced at diagnosis but also because of different tumour biology, and confounding comorbid conditions and socioeconomic factors ${ }^{18}$.

\section{Histopathological factors}

Looking at histopathological features of the primary tumour itself, ductal carcinoma is by far the most common histological type of invasive breast cancer and is diagnosed in approximately $70 \%$ of patients ${ }^{19}$. Patients with infiltrating ductal carcinomas generally have poorer clinical outcomes than patients with the less common types of infiltrating tumours ${ }^{20,21}$.

Histological grade has been proposed as a powerful prognostic factor ${ }^{22}$. However, the primary difficulties with tumour grading are poor reproducibility and lack of agreement among different investigator ${ }^{23-26}$, although not all authors agree with thi $\mathrm{s}^{27,28}$. One of the problems is the different methodologies utilized being either the histologicall evaluation of tumour grade, nuclear pleomorphism and mitotic count or an assessment of nuclear features alone. The most widely used grading system for breast cancer is the Scarff-Bloom-Richardson classification ${ }^{2,30}$. Probably a standardized and reproducible grading system could be one of the most powerful prognostic factors for breast cancer.

Tumour size is a powerful and consistent predictor of breast cancer recurrence. Several large studies have shown that the risk of disease recurrence increases as tumour size increases ${ }^{31-34}$.

No other histological factor (e.g. extensive ductal carcinoma in situ, lymphatic vessel invasion) has been fully validated as prognostic. 


\section{Steroid hormone receptors}

Most studies and especially the larger studies with longer follow-up demonstrate that patients with oestrogen-receptor (ER)-positive turnours (measured by biochemical assays) have a longer disease-free interval than patients with ERnegative tumours ${ }^{35-40}$. The disease-free survival advantage, however, is only about $10 \%$ at 3-5 years ${ }^{37.39 .41}$ and with longer follow-up disease-free intervals tend to converge ${ }^{41-44}$. Traditionally an ER level of $<10 \mathrm{fmol} / \mathrm{mg}$ cytosol protein has been used for ER-negative tumours. This cut-off point has however been questioned, while it has also been suggested that patients with a very high ER level have a worse prognosis ${ }^{45,46}$. The additional value of measuring the progesterone-receptor (PR) is uncertain. In some studies it gives no additional information to the ERstatus $^{37,43,47}$, but in other studies it is a stronger predictor of survival $\left.\right|^{38.39,48}$.

Using immunohistochemical techniques a good correlation with the standard biochemical technique was found $\mathrm{d}^{49-52}$. Theoretically this is a better method especially because direct visualization of tumour cells is possible. However, the optimal cut-off values still remain to be determined. Steroid hormone receptors are more important as predictive factors for response to hormonal therapy. Initial response rate for patients with ER- and PR-positive tumours is $60-75 \%$, whereas in patients with ER- and PR-negative tumours the response rate is less than $10 \%{ }^{53}$. Patients with a tumour that is ER-positive or PR-positive have an intermediate response rate of $25-45 \%$, whereby $P R$ is more important than $E R^{53}$. Consequently $\mathrm{ER}$ and $\mathrm{PR}$ are also predictive factors for survival after detection of the first metastasis ${ }^{54}$. PR-status has also been suggested as a powerful predictor for response to adjuvant chemotherapy ${ }^{47}$.

The pS2 gene was first identified in the human breast cancer cell line MCF-7 in response to oestrogen stimulation ${ }^{55}$. The $\mathrm{pS} 2$ protein is a small secreted protein with unknown function. It has been suggested that $\mathrm{p} S 2$ expression reflects the functional status of ER. PS2 can be determined by radioimmunoassay and by immunohistochemistry. The results of cytosolic assays tend to correlate with a good prognosis for $\mathrm{pS} 2$ positivity ${ }^{56.57}$, although this is not confirmed in all studies ${ }^{58}$. However, in immunohistochemical studies $\mathrm{pS} 2$ is not a prognostic factor ${ }^{59.66}$. At present pS2 might be useful as a predictive factor for response to hormone therapy $y^{6 !}$.

\section{Measurements of proliferation}

As in other tumours, proliferative capacity is important in breast cancer. There are many methods to measure this proliferative capacity.

The mitotic index (MI) or mitotic activity index (MAI) is determined by counting 
the number of mitoses on paraffin-embedded tumour samples stained with hematoxylin-eosin, and is usually expressed as the number of mitoses per (10) high-power field(s).

The MI is probably the oldest method of assessing proliferation, and is reproducible as shown in the Multicenter Morphometric Mammary Carcinoma Project $^{62}$. In a few studies it was demonstrated that the MI is a prognostic factor even in multivariate analysis both for disease-free survival and overall survival ${ }^{63,64}$. The MI is also a component of several prognostic indices like the Nottingham Prognostic Index ${ }^{65}$.

The thymidine labelling index (TLI) is determined by couniing the number of labelled nuclei on autoradiographed microsections following incubation of the tumour specimen with tritium-labelled thymidine. In a recent review article it was concluded that in most studies a better relapse-free and overall survival is found in patients with a slowly proliferating tumour ${ }^{66}$. Although the methods were not standardized in these studies and questions about reproducibility have been raised, a good correlation within and between laboratories is possible ${ }^{66}$. Recently a large study of 1800 node-negative breast cancer patients has confirmed an independent prognostic role for TLI ${ }^{67}$. However, the role of TLI as a predictive factor especially for response to chemotherapy has as yet not been fully demonstrated ${ }^{68-70}$. Although bromodeoxyuridine (BrdU)-labelling has been shown to give results equivalent to thymidine labelling ${ }^{71}$, formal studies on its use as a prognostic factor are lacking.

DNA flow cytometry produces a DNA histogram from which a measure of DNA content (DNA ploidy) and a measure of proliferative activity (S-phase fraction) is provided. Analysis of more than 127.000 breast cancer patients demonstrated an increased incidence of higher S-phase fractions (SPF) and aneuploidy in oestrogenand progesterone-receptor negative tumours, larger tumours, tumours with positive axillary lymph nodes and in patients younger than 35 years of age ${ }^{72}$. In a consensus conference in 1992 it was concluded that the literature supports an association between high SPF and increased risk of recurrence and mortality ${ }^{73}$. The authors advised each laboratory to establish its own distribution of diploid and aneuploid tumours rather than use published cut-off points and to use 3 rather than 2 risk groups, to reduce the chance of misclassifying tumours with near-borderline SPF values. The prognostic significance of SPF in breast cancer can probably be improved by performing it on cytokeratin-gated cell populations ${ }^{74}$. As a predictive factor for response to adjuvant chemotherapy SPF was not useful in several studies ${ }^{75.76}$, while in the metastatic setting a correllation between high SPF and a higher response rate has been reported ${ }^{77}$.

There are also immunohistochemical methods which are easier and faster in assessing the prolliferative activity. Ki67 is a monoclonal antibody that is expressed only in proliferating cells (late $G_{1}, S, M$ and $G_{2}$ phases of the cell cycle). Origin- 
ally the antibody could only be used in fresh or frozen sections. Newer antibodies like MIB- $\mathbb{1}$ are effective in fixed, archival sections after microwave irnadiation. In many studies Ki67 correlates with histological grade and inversely with steroid receptors. Most studies have found in univariate analysis a correlation between a higher number Ki67-positive cells and the risk of recurrence or death ${ }^{58-63}$. However, many studies have relatively few patients, have short follow-up and/or are composed of heterogeneous groups of node-negative and node-positive patients. More recently it has been shown that high proliferative activity as measured by Ki67 or MIB-1 antigen expression was an independent prognostic factor for survival ${ }^{8.84}$. Additional studies are clearly needed in which especially standardization of the technique is necessary.

PCNA is a nuclear protein associated with DNA polymerase delta which is present throughout the cel $\|$ cycle in proliferating cells. In general, correlations with other prognostic factors are weak. Some studies have not found a relationship of PCNA positivity and poor prognosis ${ }^{85,86}$, while others have reported such a relationship ${ }^{87,88}$.

Not many studies have compared different methods of measuring proliferation ${ }^{83.89}$. Thereby it has to be kept in mind that the above-mentioned methods reflect different parts of the cell cycle. For example the correlation between SPF and $\mathrm{Ki}$ 67 is weak at best ${ }^{83}$.

It is hard to draw definite conclusions from these comparative studies. In general an immunohistochemical marker for proliferation has many advantages: it can be carried out on small histological sections, it allows correlation with morphological features and no sophisticated technology is needed. However, more studies with standardized methods and long follow-up have to be done.

\section{Measurement of invasion/metastatic potential}

\section{Cellular adhesion molecules}

The metastatic process involves multiple steps including cell detachment from the primary tumour, degradation of the basement membrane and extracellular matrix, migration into surrounding connective tissue, entry into the vascular or lymphatic circulation, attachment to the endothelial cells in other organs, extravasation from the circulation and colony formation at secondary sites. This process may be mediated by a variety of adhesion molecules. The role of cellular adhesion molecules was reviewed in 1994\%. On most of these adhesion molecules insufficient numbers of studies have been performed to establish their usefullness as a prognostic factor. Only of some of the factors involved in invasiveness are sufficient data available to draw some preliminary conclusions. 
Cathepsin $\mathrm{D}$ can be measured in tissue sections by immunohistochemistry and in tissue extracts by Western blotting, ELISA and IRMA assays. As reviewed recently, in 12 out of 13 studies measuring cytosolic cathepsin D by IRMA a significantly worse prognosis was found for women with higher cathepsin D levels in either disease-free survival or overall survival or both ${ }^{91}$. The prognostic value of cathepsin D expression within clinical subgroups is more complex, but current studies suggest that cathepsin $D$ is of value in node-positive as well as nodenegative patients and may be of greater value in node-positive tumours ${ }^{91}$.

The results of immunohistochemical studies are much more variable ${ }^{91}$. This is caused by using different antibodies, different methods of scoring and different cutoff levels. Only one study looked at more than one antibody and showed that 3 different antibodies recognized overlapping subsets of cathepsin-D-positive tumours with a different association with metastasis-free survival ${ }^{92}$. Furthermore, there are 3 studies that show that the number of stromal macrophages is prognostically more important than staining of tumour cells ${ }^{93-95}$. This could suggest that stromal macrophages make a major contribution to the cathepsin D measured in cytosolic assays. However, other studies have demonstrated good correlations between staining of tumour cells and cytosol levels of cathepsin D measured by IRMA ${ }^{96,9 ?}$. In conclusion, also for cathepsin D large prospective studies are required to look for the most appropriate assay to define its prognostic value.

Three studies have investigated the prognostic value of the $67 \mathrm{kD}$ laminin receptor expression, with contradictory results ${ }^{98-100}$. The by far largest study looked at the prognostic value by immunohistochemistry in 1160 breast cancer patients that received no adjuvant therapy and had a follow-up of at least 20 years. The investigators found a small, but significantly increased relative risk of death of 1.33 among patients whose tumours expressed laminin receptors ${ }^{1(8)}$. The same group reported recently that the association between expression of the laminin receptor and poor prognosis is limited to laminin-producing tumours ${ }^{101}$. This supports the results of in vitro experiments that laminin and the $67 \mathrm{kDa}$ laminin receptor are associated with the metastatic process, but makes it unlikely that the $67 \mathrm{kDa}$ laminin receptor will ever be a prognostic factor with great clinical impact.

The urokinase-type plasminogen activator (UPA) is a serine protease catalysing the conversion of plasminogen into the active enzyme, plasmin. Plasmin can activate type IV collagenase which subsequently degrades collagen and proteins of the basement membranes. The binding of UPA to its receptor (UPAR) is controlled by naturally occurring inhibitors, plasminogen-activator inhibitor-1 (PAI-1) and PAI-2. UPA, PAI- 1 and PAI-2 have all been studied as prognostic markers. Because of slightly different cytosolic assays with different antibodies the studies had varying cut-off points to define assay positivity. However, in general it can be concluded that uPA ad PAI-1 give similar prognostic information: i.e., uPApositive and PAI-1-positive patients have a worse prognosis ${ }^{102-10.5}$. Conversely, high 
PAI-2 seems to be associated with longer disease-free survival in node-negative women $^{106}$ and in patients with high uPA values ${ }^{107}$. Furthermore, it has recently been reported that uPA-positive tumours more often are resistant to tamoxifen treatment than UPA-negative tumours ${ }^{108}$.

\section{Microvessel density}

There is considerable experimental evidence that tumour growth is dependent on the induction of new capillary blood vessels (angiogenesis) ${ }^{109}$. Expansion of a tumour beyond a few millimeters in diameter requires neovascularisation. Investigators using a polyclonal antiserum against factor-VIII-related antigen or a monoclonal antibody against the cell adhesion molecule, CD 31 , have proposed that counting microvessel density in tumours might provide prognostic information for predicting distant disease recurrence.

Since the original publication of Weidner and colleagues in $1991^{110}$ several studies have investigated possible correlations between microvessel density and clinical outcome in primary breast cancer. As stated in review articles in 1994 and 1995, the majority of the studies found correlations between microvessel density and relapse-free survival, overall survival or both ${ }^{11.112}$. Despite a correlation with tumour grade, tumour size and lymph node status in most studies the microvessel density was still a prognostic factor in multivariate analysis. Negative studies were criticised for methodological problems. However, recently the importance of microvessel density as a prognostic factor has been questioned ${ }^{133-115}$. Several reasons were suggested for these varying results: high intrinsic variability of the microvessel count ${ }^{113}$, the subjectivity of the process of selection and counting ${ }^{1 / 3}$ and relatively small numbers of patients with relatively short follow-up in most "positive" studies. In addition, it seems clear that the ideal endothelial marker has not yet been found. Most studies used anti-f-VIll RA or anti-CD3I but other markers like anti-CD34, anti-VEGF (vascular endothelial growth factor)-receptor antibodies or Mab E ${ }^{1 \text { 16 }}$ may be better endothelial markers. Clearly more studies are needed, especially because angiogenesis is more a marker of invasion in contrast to other currently used biomarkers which are related to differentiation or proliferation $^{1 !}$.

\section{Molecular markers}

\section{Oncogenes, growth factors and their receptors}

Several oncogenes may play a role in the development and progression of breast cancer and might therefore be correlated with prognosis. The erb-B oncogene family codes for the type I growth factor receptors of which only the epidermal growth factor receptor $(\mathrm{EGFR}=\mathrm{c}-\mathrm{erbB} 1)$ and HER-2/Neu (c-erbB-2) have been 
extensively studied.

Overexpression of EGFR is found in $35-60 \%$ of breast cancers irrespective of the method employed whether radioligand-binding assays, autoradiography, immunocylochemistry, immunoenzymatic assays, immunohistochemistry or measurement of EGFR transcripts ${ }^{12}$. Nearly all studies have reported a negative correlation between EGFR and steroid receptor status ${ }^{1: 119}$, and most studies have found an association with higher tumour grade, increased proliferative activity and aneuploidy. Several reviews summarizing the results of thousands of patients have been published in recent years ${ }^{18.119}$. Most of the reviewed studies show a significant relation between EGFR status and disease-free or overall-survival in univariate analyses, sometimes only in either nodemegative or node-positive patients. In studies with longer follow-up the initial differences tend to diminish with time. In only a proportion of the studies was a multivariate analysis performed ${ }^{1 / 49}$. Therefore, at the present time it is impossible to draw firm conclusions about the usefullness of EGFR as a prognostic factor, which is at least partly caused by lack of standardization of assay methods, short follow-up etc. ${ }^{118,120}$. It might be that EGFR is useful as a predictive factor: EGFR-positive tumours tend to be resistant to endocrine therapy

The role of HER-2/Neu (c-erbB2) as a prognostic factor has recently been reviewed ${ }^{122}$. The reviewers found multiple technical methods used and other difficulties as mentioned before for other prognostic factors. The larger studies do not support the use of HER-2/Neu as a prognostic factor in primary breast cancer, especially in node-negative patients. Looking at 18 studies using immunohistochemistry and including more than 100 patients with more than 3 years follow-up, the reviewers concluded that overexpression of HER-2/Neu adds little to the prediction of disease-free survival but may help predict overall survival, suggesting that HER-2/Neu could be a predictive factor ${ }^{122}$. Two studies found that CMP(P) adjuvant chemoherapy was not effective when the tumour was overexprossing HER-2/Neu ${ }^{123,124}$, although these studies were not designed to compare differences in response to adjuvant chemotherapy. However, in a study randomizing node-positive patients to different intensities of adjuvant CAF chemolherapy a significant dose-response effect was only found in patients with tumours overexpressing HER-2/Neu ${ }^{76}$. This discrepancy could be explaned by study design, different types of chemotherapy and other factors. HER-2/Neu overexpression was in several studies also associated with resistance to mmoxiten ${ }^{25.125}$. HER-2/Neu may have value in predicting response to a specific therapy, but the studies so far have been too few and too small to confirm the use of HER-2/Neu for this purpose.

Some studies have also been performed on amplification of other oncogenes in breast cancer. The proto-oncogene c-myc encodes a nuclear protein with sequencespecific DNA-binding activity. Amplification of c-myc is found in about $20 \%$ of 
breast cancers ${ }^{127.238}$ and is a predictor of early relapse ${ }^{127-129}$ sometimes even in multivariate analysis ${ }^{128}$.

The int- 2 gene is a member of the fibroblast growth factor family and is shown to be amplified in about $15 \%$ of primary breast cancers ${ }^{12.30}$. Amplification is a prognostic factor for early relapse but for overall survival results are contradictory ${ }^{128.130 .131}$. In most ${ }^{128.130}$ but not all ${ }^{311}$ studies the prognostic power was lost in multivariate analysis.

\section{Tumour-suppressor genes}

The p53 rumour-suppressor gene is located on chromosome 17 and mutations are found in a wide range of malignancies ${ }^{132}$. Its relation to the Li-Fraumeni syndrome makes it attractive to analyze its contribution to non-inherited breast cancer. Many studies have been published especially in the last few years about p53 and breast cancer. Most used immunohistochemical methods detecting the accumulated mutant protein and only a few used DNA-based methods such as single-strand conformation polymorphism (SSCP) analysis or DNA-sequence analysis. Only one study using SSCP found p53 mutations to have significant correlations with diseasefree survival in multivariate analysis ${ }^{133}$.

Recently it was suggested that use of a cDNA-based sequencing method yielded better prognostic information than an immunohistochemical method ${ }^{134}$. However. when a higher and more stringent immunohistochemical cutpoint was used, the differences almost disappeared ${ }^{134}$. Furthermore, DNA-sequencing is at present unsuitable for routine practice.

Looking at the larger studies using immunohistochemical methods ${ }^{1.5-146}$ only two found $p 53$ to have no prognostic value ${ }^{141.146}$ despite the use of many different monoclonal antibodies. All studies using multivariate analysis found $\mathrm{p} 53$ to be an independent prognostic factor ${ }^{136.13 \times 140,142-144}$. Therefore, it can be concluded that there is a lot of evidence linking abnormalities of $\mathrm{p} 53$ with a poor prognosis. However, as stated in a recent editorial any adverse prognostic effect is probably relatively small ${ }^{143}$. Also standardization of assays and guidelines for interpretation of the results need to be developed.

The bcl-2 protein encoded for by the bcl- 2 proto-oncogene is thought to prevent apoptosis. Therefore, an inverse correlation with p53 expression is not surprising ${ }^{148}$. In general bcl-2 expression as measured by immunohistochemistry is associated with features of differentiation and good prognosis, like ER, PR and low proliferative capacity ${ }^{148-153}$. In multivariate analyses bel-2 expression seems to have no prognostic value ${ }^{\text {14*.143, }}$, although one study did find this for the node-posilive subgroup whereby $\mathrm{p} 53$ was not studied ${ }^{152}$. Bel-2 expression increases also after tamoxifen treatment in ER-positive tumours ${ }^{151}$ and is correlated with response to endocrine therapy ${ }^{153}$.

The $\mathbf{n m} 23$ gene was originally identified in a melanoma cell line and the presence 
of nm23 mRNA correlated with low metastatic potential ${ }^{54}$. Although several smail studies reported a significant correlation between nm23 mRNA expression and longer disease-free or overall survival without performing multivariate analysis, a larger, more recent study found no relation between clinical outcome and NDP kinase/nm23 expression ${ }^{\text {ls }}$

\section{Conclusion}

Dozens of prognostic indicators have been investigated in breast cancer, including markers for tumour proliferation, oncogene and tumour suppressor gene expression, growth factors and their receptors, tumour angiogenesis and local invasiveness. Most of the information mentioned above is derived from retrospective studies with often relatively few patients and generally with short follow-up. Results are often contradictory and prognostic factors are correlated, in a different way in different studies. Certainly at present no specific prognostic factor or even a prognostic factor model can be used for treatment decisions in an individual patient.

In table 1.1 an attempt has been made to summarize current knowledge. To our opinion at present only classical prognostic factors like axillary lymph node status, tumour size, proliferative activity and probably tumour grade can be considered as established. The value of the steroid hormone receptors is mainly time-dependent and they are more meaningful as predictive factors for response to adjuvant/palliative hormonal therapy. Of the newer prognostic factors, only p53 and probably microvessel density can be considered as established prognostic factors. The data on the predictive value of a certain factor are generally based on limited studies.

At this moment it still is necessary to perform studies with large numbers of patients followed for long periods of time and using standardized assays to define uscful prognostic factors. In this respect it is important to mention the activities of the Receptor and Biomarker Study Group of the EORTC. From a theoretical point of view, especially adhesion molecules and factors associated with the formation of new blood vessels need to be studied because of their involvement in the metastatic process. Ultimately the prognosis of the patient is determined by whether meiastases develop or not.

It should be stressed that multivariate analyses which are often lacking in many studies are still necessary. Validation of results on a truly independent external population of patients is also a prerequisite. Although the studies published in the last decade have not changed the list of established prognostic factors and therefore not clinical practice, they have shed new light on the complex system of pathways that regulate human breast cancer. This has led to a newly developing field of 
potentially new therapeutic approaches. Hopefully it will be possible in the future to decide on the optimal therapy for a specific patient using prognostic factors and new therapeutic approaches derived from studies on prognostic factors.

Table 1.1. Prognostic and predictive value of some factors in women with breast cancer.

Factor 西

\section{Prognostic value}

Predictive walue

Chemotherapy flormonal theres

\begin{tabular}{|c|c|c|c|}
\hline Axillary lymph node status & + & - & " \\
\hline Histological type & - & - & - \\
\hline Histological grade & + & $?$ & ? \\
\hline Tumour size & + & - & - \\
\hline $\operatorname{Age}(<40$ yr $)$ & + & $?$ & $?$ \\
\hline Race (black) & + & $?$ & $?$ \\
\hline $\mathrm{ER}^{1}$ & \pm & - & + \\
\hline PR & \pm & - & + \\
\hline $\mathrm{pS} 2$ & - & - & + \\
\hline Proliferation $^{2}$ & + & \pm & $?$ \\
\hline EGFR: & $\mathrm{j}$ & ? & + \\
\hline HER-2/Neu & - & + & + \\
\hline p53 & + & + & $?$ \\
\hline $\mathrm{Bcl}-2$ & - & $?$ & + \\
\hline Microvessel density & + & - & - \\
\hline Cathepsin $D^{3}$ & \pm & - & + \\
\hline $67 \mathrm{kD}$ laminin-receptor & \pm & $?$ & $?$ \\
\hline UPA/PA\|- $\| / P A I-2$ & + & $?$ & + \\
\hline
\end{tabular}

$-=$ no: $+=$ yes; $\pm=$ weak or doubiful $:=$ unknow

'Time-dependent; " Optimal technique to be determined, "Cytosolic assay 


\section{References}

1. Incidence of cancer in the Nerherlands. Fourth report of the Netherlands Cancer Registry, Utrechi, $51 G$ Health Care Information; 1992.

2. Harris JR, Hellman S. Naural history of breast cancer. In: Harris JR, Lippmann ME, Mornow M, Hellman S, eds. Diseases of the breast. Philadelphia, LippincottRaven, 1996; 375-391.

3. Early Breast Cancer Trialists" Collaborative Group. Systemic treatment of early breast cancer by hormonal, cytotoxic or immune therapy. Lancet 1992; 339:1-15.

4. Early Breast Cancer Trialists' Collaborative Group. Systemic treament of early breast cancer by hormonal, cylotoxic or immune therapy. Lancet 1992; 339: 71-85.

5. Fisher B. Anderson S, Redmond CK, Wolmark N, Wickerham DL. Cronin WM. Reanalysis and results after 12 years of follow-up in a randomized clinical trial comparing total mastectomy with lumpectomy with or without irradiation in the ireatment of breast cancer. N Engl J Med 1995; 333: 1456-1461.

6. Early Breast Cancer Trialists Collaborative Group. Effects of ractiotherapy and surgery in early breast cancer - An overview of the randomized trials. N Eng! J Med 1995; 333: 1444-1455.

7. Epstein RJ. Routine or delayed axillary dissection for primary breast cancer? Eur I Cancer 1995; 31A: $1570 \cdots 1573$.

8. Fentman $1 S$, Epstein R, Barr L. Is routine axillary nodal dissection necessary in the treament of breast cancer? Eur J Cancer 1996; 32A:1460-1463.

9. Gillis CR, Hole DJ. Survival outcome of care by specialist surgeons in breast cancer: a study of 3786 patients in the west of Scotland. BMJ 1996; 312: 145-148.

10. Stoll BA. Does the malignancy of breast cancer vary with age. Clin Oncol 1976; 2 : 73-80.

11. Adami HO, Malker B. Meirik O, Persson I, Bergkvist L. Stone B. Age as a prognostic factor in breast cancer. Cancer 1985; 56: 898-902.

12. Host H. Lund E. Age as a prognostic factor in breast cancer. Cancer 1986; 57 : 2217.2221.

13. de la Rochelordiere A. Asselain B. Campana F et al. Age as prognostic factor in premenopausal breast carcinoma. Lancet 1993; 341: $1039-1043$.

14. Nixon A.J. Neuberg D. Hayes DF et all. Relationship of patient age to pathologic features of the iumor and prognosis for patients with stage I or II breast cancer. I Clin Oncol 1994: 12:888-894.

15. Abanin KS. Allred DC. Clark GM. Breast cancer outcome and predictors of outcome: are there age differentals? Monogr Natl Cancer Inst 1994; 16: 35-42.

16. Chung M, Chang HR. Bland KI, Wanebo HJ. Younger women with breast Carcinoma have a poorer prognosis than older women. Cancer 1996; 77: 97-103.

17. Miller BA, Ries LAG. Hankey BF et al. eds. SEER Cancer Statistics Review 1973w 1990. NIH publ no 93-2789. Bethesda. USDHHS National Cancer Institute; 1993.

18. Moormeier I. Breast cancer in black women. Ann Intern Med 1996: 124: 897-905. 
19. Gamel JW, Meyer JS, Fever E, Miller BA. The impact of stage and histology on the long-term clinical course of 163.808 patiens with breast carcinoma. Cancer 1996; 77 : $1459-1464$.

20. Simpson FJ, Page DL. Prognostic value of histopathology in the breast. Semin Oncol 1992; 19:254-262.

21. Rosen PP, Groshen S, Kinne DW, Norton L. Factors influencing prognosis in node negative breast carcinoma: analysis of 767 TINOMO/T2NOMO patients with long term follow-up. I Clin Oncol 1993; 11: 2090-2100.

22. Elston CW, Ellis 10 . Pathologic prognostic factors in breast cancer. 1. The walue of histologic grade in breast cancer: experience from a large study with longutern follow-up. Histopathology 1991; 19:403-410.

23. Gilchrist KW, Kalish L, Gould VE et al. Interobserver reproducibility of histopathologic features in stage II breast cancer: an ECOG sudy. Breast Cancer Res Treat $1985 ; 5: 3-10$.

24. Theissig F, Kunze KD. Haroske G, Meyer W. Histologic grading of breast cancer. Interobserver, reproducibility and prognostic significance. Pathol Res Pract 1990; 186: $732-736$.

25. Harvey MM, de Klerk NH, Sterret. GF. Histologic grading in breast cancer: interobserver agreement and relation to other prognostic factors including ploidy. Pathology 1992; 24:63-68.

26. Dalton LW, Page DL, Dupont WD. Histologic grading of breast carcinoma. A reproducibility study. Cancer 1994; 73: 2765-2770.

27. Frierson HF Jr, Wolber RA, Berean $\mathrm{KW}$ et al. Interobserver reproducibility of the Nottingham modification of the Bloom and Richardson histologic grading scheme for infiltrating ductal carcinoma. Am J Clin Pathol 1995; 103: $195-199$.

28. Robbins $\mathbb{P}$. Pinder $S$, de Klerk $N$ et al. Histologic grading of breast carcinomas: a study of interobserver agreement. Hum Pathol 1995; 26:873-879.

29. Bloom HJ, Richardson WW. Histologic grading and prognosis in breast cancer. $\mathrm{Br}$ J Cancer 1957; 11: 359-377.

30. Scarff RW, Torioni H. Histologic grading of breast tumors. Geneva, WHO, 1968; $13-20$.

31. Koscielny S, Tubiana M, Le MG el al. Breast cancer: relationship between the size of the primary tumour and the probability of metastatic dissemination. Br I Cancer 1984: 49: 709-715.

32. Moon TE, Jones SE, Bonadoma $\mathrm{G}$ et al. Development and use of a hatural history data base of breast cancer studies. An J Clin Oncol 1987; 10: $396-403$.

33. Carter CL. Allen C. Henson DE. Relationship of tumor size, lymph node status and survival in 24740 breast cancer cases. Cancer 1989; 63:181-187.

34. Rosen PP, Groshen S, Saigo P. Kime DW, Hellman S. Pathologic prognostic factors in stage 1 (TINOMO) and stage II (TINIMO) breast carcinoma: a study of 644 patients with median follow-up of 18 years. J Clin Oncol 1989; 7: 1239-1251

35. Knight WOE III, Livingstone RB, Gregory EG, McGuire WL. Oestrogen-receptor as an independent prognosic factor for early recurrence in breast cancer. Cancer Res 1977; 37: 4669-4671. 
36. Williams MR, Todd $/ H$, Ellis 10 et al. Oestrogen-receptors in primary and advanced breast cancer: an eight-year review of 704 cases. Br J Cancer 1987; 55: 67.73 .

37. Fisher B, Redmond C, Fisher ER, Caplan R. Relative worth of estrogen and progesterone receptor and pathologic characteristics of differentiation as indicators of prognosis in node-negative breast cancer patients: findings from National Surgical Adjuvant Breast and Bowel Protocol B-06. J Clin Oncol 1988; 6: 1076-1087.

38. Alexieva-Figusch J, van Putten WL, Blankenstein MA, Blonk van der Wijst J, Klijn JG. The prognostic value and relationships of patient characteristics, estrogen and progesin receptors, and sile of relapse in primary breast cancer. Cancer 1988; 61: $758-768$.

39. Clark GM, McGuire WL. Steroid receptors and other prognostic factors in primary breast cancer. Semin Oncoll 1988; 15 (supp): 20-25.

40. Molino A. Turazza M, Bonetti A et al. Estrogen and progesterone receptors in breast cancer: correlation with clinical and pathological features and with prognosis. Oncology 1992; 49:82-88.

41. Raemaekers JMM, Beex LVAM, Koenders AJM et al. Disease-free interval and estrogen receptor activity in tumor tissue of patients with primary breast cancer: Analysis after long-term follow-up. Breast Cancer Res Treat 1985;6: 123-130.

42. Mason BH, Holdaway IM, Mullins PR, Yee LH, Kay RG. Progesterone and estrogen receptors as prognostic variables in breast cancer. Cancer Res 1983; 43: 2985-2990.

43. McGuire WL, Tandon AK, Allred DC, Chamness GC, Clark GM. How to use prognostic factors in axillary node-negative breast cancer patients. I Natl Cancer Inst 1990; 82: 1006-1015.

44. Sigurdsson $\mathrm{H}$, Baldetorp $\mathrm{B}$, Borg $\mathrm{A}$ et al. Indicators of prognosis in node-negative breast cancer. N Engl J Med 1990; 322: 1045-1053.

45. Thorpe SM, Christensen IJ, Rasmussen BB, Rose C. Short recurrence-free survival associated with high oestrogen receptor levels in the natural history of postmenopausal, primary breast cancer. Eur J Cancer 1993; 29A: $971-977$.

46. Hupperets PSGJ. Prognostic and predictive factors in primary breast cancer. Thesis. Universitaire Pers, Maastricht; 1995: 57-68.

47. Raemakers JMM, Beex LVAM, Pieters GFFM et al. Progesterone receptor activity and relapse-free survival in patients with primary breast cancer: the role of acjuvant chemotherapy. Breast Cancer Res Treat 1987:9: 191-199.

48. Thorpe SM, Rose C, Rasmussen BB, Mouridsen HT, Bayer T, Keiding $N$. Prognostic value of steroid hormone receptors: multivarate analysis of systemically untreated patients with node-negative primary breast cancer. Cancer Res 1987; 47: 6126-6133.

49. MeCarty KS Jr, Miller LS, Cox EB, Konrath J, McCarty KS Sr. Estrogen receptor analyses "correlation of biochemical and immunohistochemical methods using monocional antireceptor antibodies. Arch Path Lab Med 1985; 109: 716-721. 
50. De Lena M, Marzullo F, Simone $G$ et al. Correlation between ERICA and DCC assay in hormone receptor assessment of human breast cancer. Oncoloy 1988;45: $308-312$.

51. Katz RL, Patel S, Sneige $\mathbb{N}$ et al. Comparison of immunocytochemical and biochemical assays for estrogen receptor in fine needle aspirates and histologic sections from breast carcinomas. Breast Cancer Res Treat 1990; 15: 191-203.

52. Molino A, Micciolo R, Turazza $M$ et al. Estrogen receptors in 699 primary breast cancers: a comparison of immunohistochemical and biochemical methods. Breast Cancer Res Treat 1995; 34: $221-228$.

53. Honig SF. Treatment of metastatic disease. In: Harris JR, Lippmann ME, Morrow M, Hellman S, eds. Diseases of the Breast, Philadelphia, Lippincont-Raven, 1996 ; $669-734$.

54. Koenders PG, Beex LVAM, Kloppenborg PWC, Smals AGH, Benraad TI and the Breast Cancer Study Group. Human breast cancer: survival from first metastasis. Breast Cancer Res Treat 1992;21: 173-180.

55. Masiakowski $P$, Breatnach $R$, Bloch $\pi$, Gannon $F$, Krust $A$, Chambon $P$. Cloning of CDNA sequences of hormone regulated genes from the $\mathrm{MCF}-7$ human breast cancer cell line. Nucleic Acids Res 1982; 10: 7895-7903.

56. Foekens JA, van Putten WLJ, Portengen $H$ et al. Prognostic value of $\mathrm{pSz}$ and cathepsin $D$ in 710 primary breast tumors: a multivariate analysis. I Clin Oncol $1993 ; 11: 899-908$.

57. Gion M, Mione R, Pappagallo GL et al. PS2 in breast cancer - alternative or complementary tool to steroid receptor status? Evaluation of 446 cases. Br I Cancer 1993; $68: 374-379$.

58. Speiser P, Stolzlechner J, Haider $K$ et al. PS2 protein status fails to be an independent prognostic factor in an average breast cancer population. Anticancer Research 1994; 14: 2125-2130.

59. Thor AD, Koerner FC, Edgerton SM, Wood WC, Stracher MA, Schwartz LH. PS2 expression in primary breast carcinomas: relationship to clinical and histological features and survival. Breast Cancer Res Treat 1992; 21: $111-119$.

60. Soubeyran J, Wafflart J, Bonichon F et al. Immunohistochemical determination of pS2 in invasive breast carcinomas: a study on 942 cases. Breast Cancer Res Treat 1995: $34: 119-128$.

61. Foekens $\mathbb{I A}$, Portengen $H$, Look MP et al. Relationship of $\mathrm{pS2}$ with response to tamoxifen therapy in patients with recurrent breast cancer. Br J Cancer 1994: 70: 1217-1223.

62. Van Diest PJ, Baak JPA, Matze-Cok P et al. Reproducibility of mitosis counting in 2469 breast cancer specimens: results from the Multicenter Morphometric Mammary Carcinoma Project. Hum Pathol 1992; 23; 603-607.

63. Russo J, Frederick J, Ownby $\mathrm{HE}$ et al. Predictors of recurrence and survival of patients with breast cancer. Am J Clin Pathol 1987: 88: 123-131.

64. Clayton F. Pathologic correlates of survival in 378 lymph node-negative infiltrating ductal breast carcinomas. Mitotic count is the best single predictor. Cancer 1991 ; 68: 1309-1317. 
65. Galea MH, Blamey RW, Elswon CE, Ells 10. The Nottingtham Prognostic Index in primary brast cancer. Breast Cancer Res Treat 1992: 22: 207-219.

66. Silwestrini R. Cell kinetics: prognostic and therapeutic implications in human tumours. Cell Prolif 1994; 27: 579-596.

67. Silvestrini $\mathrm{R}$, Daidone $\mathrm{MG}$, Lüsi $\mathrm{A}$ et al. Biological and clinicopathologic factors as indicators of specific relapse types in node-negative breast cancer. I Clin Oncol 1995: 13: 697.704 .

68. Zambeti $M$, Bonadonna $G$, Valagussa $P$ et al. Adjuvant $C M F$ for node-negative and estrogen-receptor negative breast cancer patients. Monogr Natl Cancer Inst 1992; $11: 77-83$.

69. Daidone MG. Silwestrini R, Valentinis B, Ferrari L, Bartoli C. Changes in cell kinetics induced by primary chemotherapy in breast cancer. Int $\int$ Cancer $1991: 47$ : $380-383$.

70. Gardin G, Alama A, Rosso $R$ et al. Relationship of variations in tumor cell kinetics induced by primary chemotherapy to tumor regression and prognosis in locally advanced breast cancer. Breast Cancer Res Treat 1994; $32: 311-318$.

71. Weicher N, Moore DH 2d, Ljung BM et al. Correlation of bromodeoxyuridine (BrdU) labeling of breast carcinoma cells with mitotic figure content and tumor grade. Am J Surg Path 1993; 17: $987-994$.

72.. Wenger CR, Beardslee $\mathrm{S}$, Owens MA el al. DNA ploidy, S-phase and steroid receptors in more than 127.000 breast cancer patients. Breast Cancer Res Treat 1993: $28: 9-20$.

73. Hedley DW, Clark GM, Cornelisse CJ, Killander D, Kute T, Merkel D. Consensus review of the clinical utility of DNA cytometry in carcinoma of the breast. Breast Cancer Res Treat 1993; 28: 55-59.

74. Wingren S, Stal O, Sullivan S, Brisfors A, Nordensikjöld B. S-phase fraction after gating on epithelial cells predicts recurrence in node-negative breast cancer. Int I Cancer 1994; $59: 7-10$.

75. Dressler LG, Eudey L. Gray R et al. Prognostic potential of DNA flow cytometry measurements in node-negative breast cancer patients: preiminary analysis of an Inergroup study (INT 0076). Monogr Nat Cancer Inst 1992; 11: 167-172.

76. Muss HB, Thor AD, Berry DA et al, C-erbB-2 expression and response to adjuwant therapy in women with nodempositive early breast cancer. N Engl J Med 1994; 330: $1260-1266$.

77. Hielanen P, Blomqvist C, Wasenius VM, Niskanen E, Franssila K, Nordling S. Do DNA-ploidy and $S$-phase fraction in primary tumour predict the response to chemotherapy in melastatic breast cancer. Br J Cancer 1995; 71: 1029-1032.

78. Bouzubar $\mathrm{N}$, Walker RJ. Griftiths $\mathrm{K}$ et al. Ki-67 immunostaining in primary breast cancer: pathologic and clinical associations. Br J Cancer 1989; 59; 943-947.

79. Winzer HO, Ziptel I, Schulte-Monting J, Hellerich U, won Kleist S. Ki-67 immunostaining in buman breast tumors and its relationship to prognosis. Cancer $1991: 67: 421-428$.

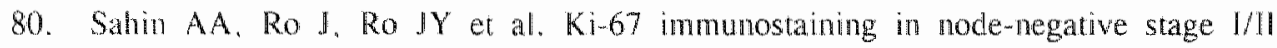
breast carcinoma. Significant correlation with prognosis. Cancer 1991; 68: 549.557. 
81. Veronese SM, Gambacorta M, Gotardi O. Scanzi F. Ferrario M. Lampentico P. Proliferation index as a prognostic marker in breast cancer. Cancer 1993; $71: 3926$ 3931.

82. Weikel W, Brumm C, Wilkens C, Beck T, Knapstein PG. Growth fractions (Ki-67) in primary breast cancers, with particular reference to node-negative umors. Cancer Detection and Prevention 1995; 19: 446-450.

83. Brown RW. Altred DC, Clark GM, Osborne CK, Hilsenbeck SG. prognostic value of Ki.67 compared to S-phase fraction in axillary node-negative breast cancer. Clin Cancer Res 1996; 2: 585-592.

84. Jensen V, Ladekarl M, Holm-Nielsen P, Melsen F, Soerensen FB. The prognostic value of oncogenic antigen 519 (OA-519) expression and proliferative activity detected by antibody MIB-I in node-negarive breast cancer. J Pathol 1995; 176: $343-352$.

85. Bianchi S, Paglierani M, Zampi G. Prognostic value of prolterating cell nuclear antigen in lymph node negative breast cancer patients. Cancer 1993; 72: 120-125.

86. Thomas M, Noguchi M, Kitagawa H, Kinoshita K, Miyazaki I. Poor prognostic value of proliferating cell nuclear antigen labelling index in breast carcinoma. I Chin Pathol 1993; 46:525-528.

87. Sitonen SM, Kallioniemi OP, Isola $1 J$. Proliterang cell muclear antigen immunohistochemistry using monoclonal antibody $19 \mathrm{~A} 2$ and a new antigen retrieval technique has prognostic impact in archival paraffin-embedded node-negative breast cancer. Am J Path 1993; 1 42: 1081-1089.

88. Tahan SR, Neuberg SD, Dieffenbach A, Yacoub L. Prediction of early relapse and shortened survival in patients with breast cancer by proliferating cell nuclear antigen score. Cancer 1993; 71: 3552-3559.

89. Gasparini G, Boracchi P. Verderio P, Bevilacqua P. Cell kinetics in human breast cancer: comparison between the prognostic value of the cytofuorimetric S-phase fraction and that of the antibodies to Ki-67 and PCNA antigens detected by immunocyrochemistry. Int J Cancer 1994:57:822 829.

90. Maemura M, Dickson RB. Are cellular adhesion molecules involved in the metastasis of breast cancer? Breast Cancer Res Treat 1994; 32: 239-260.

91. Westley BR, May FEB. Cahepsin D and breast cancer. Eur J Cancer 1996; 32A: $15-24$.

92. Eng Tan P. Benz CC, Dollbaum C et al. Prognostic value of callepsin D expression in breast cancer: immunohistochemical assessment and correlation with radiometric assay. Ann Oncol 1994: $5: 329-336$.

93. Tetu B, Brisson I, Cote C. Brisson S, Porvin D, Raberge N. Prognostuc signilicance of cathepsin D expression in node-positive breast carcinoma: an immunohistochenical study. Int I Cancer 1993; 55: 429-435.

94. Joensuu H, Toikkanen S. Isola J. Stromal cell cathepsin D expression and long-term survival in breast cancer. Br J Cancer 1995; 71: 155-159.

95. ODonoghue AEMA, Poller DN. Bell IA et al. Cathepsin D in primary breast carcinoma: adverse prognosis is associated with expression of cathepsin $D$ in stromal cells. Breast Cancer Res Treat 1995; 33: 137-145. 
96. Roger P. Montcourrier P, Maudelonde $T$ ef al. Cahepsin D immunostaining in paraffin cmbedded breast cancer cells and macrophages; correlation with cytosolic assay. Human Pathol 1994: 25: 863-871.

97. Gohring UJ, Scharl A. Thelen U, Ahr A, Crombach G, Titius BR. Prognostic value of cathepsin $D$ in breast cancer: comparison of immunohistochemical and immunoradiomeiric detection methods. J Clin Path 1996; 49: 57-64.

98. Marques LA, Franco ELF. Torloni H, Brentani MM, da Silva Neto JB, Brentani RR. Independent prognostic value of aminin receptor expression in breasi cancer survival. Cancer Res 1990; 50: 1479-1483.

99. Daidone $M G$, Silvestrini $R$, D'Errico $A$ et al. Laminin receptors, collagenase IV and prognosis in mode-negative breast cancers. Int J Cancer 1991; 48: 529-532.

100. Martignone $S$, Menard $S$, Bufalino $R$ et al. Prognostic significance of the 67 kilodalton laminin receptor expression in human breast carciomas. I Natl Cancer Inst $1993 ; 85: 398-402$.

101. Pellegrini $R$, Martignone $S$, Tagliabue $E$ et al. Prognostic significance of laminin production in relation with is receptor expression in human breast carcinomas. Breast Cancer Res Treat 1995; 35: 195-199.

102. Grondahl-Hansen J, Christensen IJ, Rosenquist C et al. High levels of urokinasetype plasminogen activator and its inlubitor PAI- 1 in cytosolic extracts of breast carcinomas are associated with poor prognosis. Cancer Res 1993; 53: 2513-2521.

103. Janicke F, Schmitt M, Pache $L$ et al. Urokinase (uPA) and its inhibitor PAI-1 are strong and independent prognostic factors in nodewegative breast cancer. Breast Cancer Res Treat 1993; 24: 195-208.

104. Foekens $\amalg A_{\text {, Schmitt }} M_{*}$ van Putten WLJ et al. Plasminogen activator inhibitor-1 and prognosis in primary breast cancer. J Clin Oncol 1994; 12: $1648-1658$.

105. Duffy MI, Reilly D, McDermott E, O'Higgins N, Fennelly JJ, Andreasen PA. Urokinase plasminogen activator as a prognostic marker in different subgroups of patients with breast cancer. Cancer 1994; 74: 2276-2280.

106. Bouchet C., Spyratos F. Martin PM, Hacène K, Gentile A, Oglobine J. Prognostic value of urokingse-lype plasminogen activator (uPA) and plasminogen activator inhibitors PAI-1 and PAI-2 in breast carcinomas. Br J Cancer 1994; 69: $398-405$.

107. Foekens JA, Buessecker F, Peters HA et al. Plasminogen activator inhibitor-2: prognostic relevance in 1012 patients with primary breast cancer. Cancer Res 1995; 55: $1423-1427$

108. Foekens JA, Look MP, Peters HA, van Putten WL. Portengen H, Klijn JG. Urokinase-type plasminogen activator and its nhibitor PAI-1: predictors of poor response to tamoxifen therapy in recurfent breast cancer. I Natl Cancer Inst 1995; $87: 751-756$

109. Folkman $J$. What is the evidence that tumors are angiogenesis dependent? Natl Cancer Inst 1990; 82:46.

110. Weidner NW, Semple JP, Welch WR, Folkman J. Tumor angiogenesis and metastasis - correlation in invasive breast carcinoma. N Engl J Med 1991; 324: 1-8.

111. Craft PS, Harris AL. Clinical prognostic significance of tumour angiogenesis. Ann Oncol 1994; $5: 305-311$. 
112. Gasparini $G$, Harris AL. Clinical importance of the determination of tumor angiogenesis in breast carcinoma: much more than a new prognostic tool. I Chin Oncol 1995; 13: 765-782.

113. Axelsson $\mathrm{K}$, Ljung BME, Moore II DH et al. Tumor angiogenesis as a prognosite assay for invasive ducial breast carcinoma. INatl Cancer Inst 1995; 87: 997-1008.

114. Siitonen SM, Haapasalo HK. Rantala IS, Helin HJ. Isola JJ. Comparison of different immunohistochemical methods in the assessment of angiogenesis: lack of prognostic value in a group of 77 selected node-negative breast carcinomas. Mod Pathol 1995; 8: 745-752.

115. Goulding H, Nik Abdul Rashid NF, Robertson IF et al. Assessment of angiogenesis in breast carcinoma: an important factor in prognosis? Hum Pathol 1995: 26: 1196 1200.

116. Wang JM, Kumar S, Pye D, Haboubi N, Al-Nakib L. Breast carcinoma: comparative study of tumor vasculature using two endothelial cell markers. I Natl Cancer Inst 1994; 86: 386-388.

117. Hayes DF. Angiogenesis and breast cancer. Hematol Oncol Clin North Am 1994; 8 (1): $51-71$.

18. Fox SB, Smith K, Hollyer I, Greenall M, Hastrich D, Harris AL. The epidermal growth factor receptor as a prognostic marker: results of 370 patients and review of 3009 patients. Breast Cancer Res Treat 1994; 29:41-49.

119. Klijn JGM, Berns PMJ, Schmitz PIM, Foekens JA. The clinical significance of epidermal growth factor receptor $(\mathrm{EGF}-\mathrm{R})$ in human breast cancer: a review on 5232 patients. Endocr Rev 1992; 13:3-17.

120. Koenders PG, Beex LVAM, Geurts-Moespot A, Heuvel IJTM, Kienhuis CBM, Benraad TJ. Epidermal growth factor receptorwnegative tumors are predominanty confined to the subgroup of estradiol receptor-positive human promary breasi cancers. Cancer Res 1991; 51:4544-4548.

121. Nicholson RI, McClelland RA, Gee IMW et al. Epidermal growth factor receptor expression in breast cancer: association with response to endocrine therapy. Breast Cancer Res Treat 1994; 29: 117-125.

122. Ravdin PM, Chamness GC. The c-erbB-2 proto-oncogene as a prognostic and predictive marker in breast cancer: a paradigm for the development of othet macromolecule markers - a review. Gene 1995; 159: 19-27.

123. Gusterson BA, Gelber RD, Goldhirsch A et al. Prognostic importance of c-erbB-2 expression in breast cancer. J Clin Oncol 1992; 10: 1049-1056.

124. Allred DC, Clark GM, Tandon AK et al. HER-2/Neu in node-negative breast cancer: prognostic significance of overexpression influenced by the presence of in situ carcinoma. J Clin Oncol 1992; 10: 599-605.

125. Wright C, Nicholson S, Angus B et al. Relationship between c-erbB-2 protein product expression and response to endocrine therapy in advanced breast cancer. $\mathrm{Br}$ J Cancer 1992: 65: 118-121.

126. Klijn JG, Berns EM, Bontenbal M, Foekens J. Cell biological factors associated with the response of breast cancer to systemic treatment. Cancer Treat Rev 1993: 19. (suppl B): 45-63. 
127. Berns EMIJ, Foekens JA, van Puten WLJ el al. Prognostic factors in human primary breast cancer: comparison of c-myc and HER-2/Neu amplification. I Steroid Biochem Molec Biol 1992; 43: $13-19$.

128. Berns EMJJ, Foekens JA, wan Staveren IL el al. Oncogene amplification and prognosis in breast cancer; relationship with systemic treament. Gene 1995; 159: $11-18$.

129. Roux-Dosetto M. Martin PM. A paradigm for oncogene complementation in lnuman breast cancer. Res Virol 1989: 140: $571-591$.

130. Borg A, Sigurdsson H. Clark GM et al. Association of INT2/HST-1 coamplification in primary breast cancer with hormone-dependent phenotype and poor prognosis. $\mathrm{Br}$ J Cancer 1991; 63: 136-142.

131. Schuring $\mathbf{E}_{\text {. Verhoeven }} \mathrm{E}$, van Tinteren $\mathrm{H}$ et al. Amplification of genes with the chromosome 11913 region is indicative of poor prognosis in patients with operable breast cancer. Cancer Res 1992; 52: 5229-5234.

132. Hollstein M, Sidransky D. Vogelstein B, Harris CC. P53 mutations in human cancers. Science 1991; 253:49-53.

133. Elledge RM. Fuqua SAW. Clark GM, Pujol P, Allred C, McGuire WL. Prognostic significance of p53 gene alterations in node-negative breast cancer. Breast Cancer Res Treat 1993; 26: 225-235.

134. Sjögren $S$, Inganäs $M$, Norberg $T$ et al. The $p 53$ gene in breast cancer: prognostic value of complementary DNA sequencing versus immunohistochemistry. I Natl Cancer Inst 1996; 88: 173-182.

135. Sawan A, Randall B. Angus B et al. Reinoblastoma and p53 gene expression related to relapse and survival in lnuman breast cancer: an immunohistochemical study. J Pattiol 1992; 168: 23-28.

136. Isola I, Visakorpi T, Holli K, Kallioniemi P. Association of overexpression of tumor suppressor protein 053 with rapid cell proliferation and poor prognosis in node-negative breast cancer patients. J Natl Cancer Inst 1992; 84: 1109-1114.

137. Silvestring R. Benini E, Daidone MG at al. p53 as an independent prognostic market in lymph nodenceative breast cancer patients. I Natl Cancer Inst 1993; 85: $965-970$.

138. Barnes DM, Dublin EA. Fisher CJ. Levison DA. Millis RR. Immunohistochemical detection of 553 protein in mammary carcinoma: an important new independent indicator of prognosis? Hum Pathol 1993: 24: 469m476.

139. Lipponen P, di H. Aalioman S. Syrjänen S. Syrjänen K. p53 protein expression in breast cancer as related to histopathological characteristics and prognosis. Int I Cancer 1993: $55: 51-56$.

140. Alled DC, Clark GM, Elledge R el al. Association of p53 protein expression with umor cell proliteration rate and clinical outcome in node-negative breast cancer. I Nall Cancer Inst 1993; 85: 200-206.

141. Hurlimann NJ. Prognostic value of p53 protein expression in breast carcinomas. Pathol Res Pract 1993; 189: 996-1003.

142. Friedrichs $K$, Gluba $S$, Eidmann $H$, Jonat $W$. Overexpression of $\mathrm{p} 53$ and prognosis in breast cancer. Cancer 1993; 72: 3641-3647. 
143. Marks IR, Humphrey PA. Wu K el al. Overexpression of p53 and HER-2/new proteins as prognostic markers in early stage breast cancer. Ann Surg 1994; 219 : $332-341$.

144. Gasparini $G$, Weidner $N$. Bevilacqua $P$ et al. Tumor microvessel density, p53 expression, tumor size and peritumoral lymphatic vessel invasion are relevant prognostic markers in node-negative breast carcinoma. J Clin Oncol 1994; 12:454466.

145. Elledge RM, Clark GM, Fuqua SAW, Yu YY, Allred DC. p53 protein accumulation detected by five different antibodies. relationship to prognosis and heat shock protein 70 in breast cancer. Cancer Res 1994; 54: 3752-3757.

146. Pietilainen T, Lipponen P, Aaltomaa $S$. Eskelnen $M$, Kosma VM, Syrjänen $K$. Expression of p53 protein has no independent prognostic value in breast cancer. I Pathol 1995; 177: 225-232.

147. Dowell SP, Hall PA. The p53 tumour suppressor gene and tumour prognosis: is there a relationship? J Pathol 1995; 177:221-224.

148. Sivestrini $R$, Veneroni $S$, Daidone $M G$ et al. The bel-2 protem: a prognostic indicator strongly related to p53 protein in lymph node negative breast cancer patients. INatl Cancer Inst 1994; 86: 499 504.

149. Joensuu $H$, Pylkkanen L, Toikkanen S. Bcl-2 protein expression and long-term survival in breast cancer. Am J Path 1994; 145: 1191-1198.

150. Nathan B, Gusterson B, Jadayel D et al. Expression of bolm 2 in primary breast cancer and its correlation with tumour phenotype. Ann Oncol 1994; 5: 409-414.

151. Johnston SRD, MacLennan KA, Sacks NPM, Satter J, Smith IE, Dowsett M. Modulation of bcl-2 and ki-67 expression in oestrogen receptor positive iumor breast cancer by tamoxifen. Eur J Cancer 1994; 30A: 1663-1669.

152. Hellemans P, van Dam PA, Weyler J, van Oosterom AT, Buytaer P, van Marck E. Prognostic value of bcl-2 expression in invasive breast cancer. Br 1 Cancer 1995; 72: $354-360$.

153. Gee JMW, Robertson JFR, Ellis 10 el al. Immunocytochemical localization of bcl-2 protein in human breast cancers and its relationship to a series of prognostic markers and response to endocrine therapy. Int I Cancer 1994; 59:619-628.

154. Steeg PS, Bevilacqua G, Pozzati R, Lionta LA, Sobel ME. Altered expression of mm23, a gene associated with low tumor metastatic potential, during adenovirus 2Ela inhibition of experimental metastasis. Cancer Res 1988: 48: 6550-6554.

155. Sawan A, Lascu 1, Veron M et al. NDP K/nm23 expression in luman breast cancer in relation to relapse, survival and other prognostic factors: an immunohistochemical study. J Pathol 1994; 172: 27-34. 


\section{Chapter IB}

\section{This thesis}

RLH Jansen 
Prognostic and predictive factors in breast cancer

34 


\section{This thesis}

The work described in this thesis, tried to overcome some of the problems which are inherent to many of the previous studies on prognostic factors in breast cancer as mentioned in chapter IA. We have investigated the prognostic value of several factors in all known patients, diagnosed with primary breast cancer over a period of about five years in the University Hospital Maastricht. The median follow-up period was more than 10 years. Furthermore, during this period adjuvant treatment after surgery was uniform as much as possible. Axillary node-positive patients below the age of 70 years were treated with chemotherapy consisting of 5 fluorouracil, adriamycin and cyclophosphamide. The majority of these patients were treated according to a protocol for concomitant treatment with medroxyprogesterone-acetate (MPA) or no MPA. Axillary node-positive patients of 70 years and older were treated with adjuvant tamoxifen. Axillary node-negative patients received no adjuvant treatment.

This cohort of patients was used to investigate several possible prognostic factors that are involved in tumor growth, apoptosis and the process of metastasis.

In Chapter II the prognostic significance of the pS2 protein was studied. $\mathrm{pS} 2$ has been associated with the functional status of the oestrogen receptor but is probably also involved in growth regulation. Furthemore the prognostic value of the adhesion molecule CD44v6 (Chapter III), the proliferation marker MIB-1 (Chapter IV), the proto-oncogene bcl-2 and the tumour suppressor gene p53 (Chapter $\mathrm{V}$ ) and of microvessel density (Chapter VI) were analyzed. All factors were studied by immunohistochemical methods. 


\section{Chapter II}

\section{pS2 is an independent prognostic factor for post- relapse survival in primary breast cancer}

RLH Jansen, PSGJ Hupperets, JW Arends, SR JoostenAchjanie, A Volovics, HFP Hillen, HC Schouten 


\section{Abstract}

\section{Background}

The 152 protein is involved in the mantenance of the integrity of the gastrointestimal tract. In breast cancer $\mathrm{pS} 2$ can be demonstrated in at least half of the tumours and probably reflects the functional status of ER. Several features make it likely that pS2 is involved in growth regulation.

\section{Patients and Methods}

We have investigated the vafue of immunohistochemical pS2 determination as a prognostic factor in 339 breast cancer patiens with long follow-up from one hospital.

\section{Resullts}

A prognostic role for pS2 could not be demonstrated considering disease-free and owerall survival, although in p52-negative tumours a trend for less locoregional relapse was found. However, in multivariate analysis pS2 showed independent prognostic value for post-relapse surwival.

\section{Concllusions}

PS2 is an independent prognostic factor for post-relapse survival, most likely because it is a predictive factor for response to systemic therapy. 


\section{Introduction}

Twenty years ago the first of many reports on the prognostic significance of the oestrogen-receptor (ER) in patients with breast cancer was published. The larger studies with longer follow-up consistently demonstrate that disease-free survival in patients with ER-positive tumours is longer than in patients with ER-negative tumours $^{1-6}$. The disease-free survival advantage is $8-10 \%$ at 5 years ${ }^{3.5}$, but the difference tends to decrease with time ${ }^{7-9}$. A variety of proteins functionally related to the oestrogen-receptor have been reported to have prognostic significance in breast cancer, including the progesterone receptor (PR), cathepsin $D$ and the $p S 2$ protein. The $\mathrm{pS} 2$ protein was first identified in the human breast cancer cell line MCF-7 in response to oestrogen stimulation ${ }^{10}$. The $\mathrm{pS} 2$ protein is a small $(6.45 \mathrm{kD})$ protein of repair function, and belongs to the trefoil peptides, that are mainly expressed in the gastrointestinal mucosa ${ }^{11}$. The expression of pS2 and other trefoil peptides like pancreatic spasmic polypeptide is induced in inflammatory and ulcerative settings in the gastrointestinal tract and they have probably an important function in the maintenance of the gastrointestinal integrity ${ }^{12}$. In tumours of the stomach ${ }^{13}$, biliary tract $^{14}$, pancreas ${ }^{15}$, colon and rectum ${ }^{16}$ the $\mathrm{pS} 2$ protein has also been demonstrated. In normal breast tissue $\mathrm{pS} 2$ expression is lower than in uninvolved breast tissue from mastectomies for breast carcinomas $^{67}$. This could indicate that some biochemical changes have taken place in the apparently uninvolved breast tissue during the development of the carcinoma. These changes could be hormone dependent because it has been suggested that pS2 expression reflects the lunctional status of ER. The fact that the $\mathrm{pS} 2$ gene has an upstream enhancer region that is responsive to oestrogen, plasminogen activator, activated Fos and Jun oncoproteins, the phorbol ester tetradecanoyl phorbol acetate (TPA) and epidermal growth factor (EGF) make it likely that $\mathrm{pS} 2$ is involved in growth regulation. This makes it attractive io investigate $\mathrm{pS} 2$ as a prognostic factor in breast cancer.

In human breast cancer associations have been demonstrated between $\mathrm{PS} 2$ and $\mathrm{ER}$ and PR status ${ }^{1820}$. Most studies, however, have found no significant associations between $\mathrm{pS} 2$ and nodal status or tumour size ${ }^{45.20}$. First studies investigating the prognostic significance have used radioimmunoassays, and generally it has been reported that pS2 positivity is associated with a better relapse-free and overall survival ${ }^{19,21,22}$. Sometimes, this has been observed, however, only for overall survival ${ }^{23}$, in a small group of patient ${ }^{20}$ or not at all ${ }^{24}$. Several other investigators have determined the pS2 status by immunohistochemical techniques. Alhough similar rates of $\mathrm{pS} 2$ positivity have been observed compared with studies using radioimmunoassays, generally an association between immunohistochemical pS2 status and clinical outcome has not been found ${ }^{25.26,27}$. However, in some investigations trends for better overall survival have been demonstrated for $\mathrm{pS} 2$ positive patients ${ }^{27.28}$. These results could suggest that $\mathrm{pS} 2$ merely is at predictive 
factor for response to hormonal therapy for both primary ${ }^{23}$ and advanced breast cancer $^{29}$.

In order to elucidate the prognostic significance and also the predictive value of pS2 status as determined by immunohistochemical techniques we investigated a group of 339 patients from one hospital with a long follow-up period.

\section{Patients and Methods}

\section{Patients}

The 339 patients were treated at the University Hospital of Maastricht, between May 1982 and August 1987. Patients were selected according to the following criteria: 1. primary unilateral breast cancer without distant metastases, 2. no other primary tumour, 3 . histological material available.

The clinical, histological and biological information on all patients were entered on a computerized database. All patients were staged at the time of diagnosis according to the International Union Against Cancer TNM Classification ${ }^{30}$. The median age was 57 years (range $25-87$ years). Two hundred and twenty-two patients $(65.5 \%)$ had undergone a modified radical mastectomy, 98 patients $(28.9 \%)$ a lumpectomy with axillary lymph node dissection and in 19 patients $(5.6 \%)$ only a biopsy was performed either because of $T_{4}$ stage or high age, in two cases with an axillary lymph node dissection. One hundred eighty-three patients $(54.0 \%)$ had no axillary lymph node metastases, while in 139 patients $(41.0 \%)$ metastases were found in one or more axillary lymph nodes. Axillary lymph nodenegative patients received no adjuvant systemic therapy. Axillary lymph nodepositive patients below the age of 70 years were treated with adjuvant chemotherapy consisting of 5-fluorouracil, adriamycin and cyclophosphamide. If these patients agreed, in addition they were randomized for concomitant treatment with MPA or no MPA. Clinical results of this multicenter trial have been described more in detail elsewhere ${ }^{3,32}$. Axillary node-positive patients older than 69 years were treated with tamoxifen. The median follow-up was 128 months (range 61-170 months). One hundred fourty-seven patients experienced a relapse during the follow-up period: 45 had a locoregional relapse, 85 distant metastases and 17 both simultaneously at the moment of first relapse.

\section{Methods}

\section{ER and PR-status}

The ER and PR assays were all performed on histologically proven breast cancer tissues using the dextran-coated charcoal method with multiple-point scatchard-plot 
analysis ${ }^{33}$.

For all the assays the minimum cytosol protein concentration was $2 \mathrm{mg} / \mathrm{ml}$ cytosol. PR status was determined only in patienis entered from August, 1983.

Tumours were considered ER- or PR-positive when containing $>10 \mathrm{fmol} / \mathrm{mg}$ protein.

\section{Immunohistochemical pS2-assay}

Three $\mu \mathrm{m}$ sections were cut from routinely formalin-fixed and paraffin-embedded archival tumour samples. Deparaffinization in xylene and washes in $100 \%$ ethanol were followed by removing endogenous peroxidase in $0.3 \% \mathrm{H}_{2} \mathrm{O}_{2}$ in methanol during 30 minutes at room temperature. After washing away the excessive amount of methanol in demineralized water trypsin digestion was performed. For this purpose the slides were incubated at $37^{\circ} \mathrm{C}$ for 10 minutes in $0.1 \%$ trypsin $(\mathrm{pH}=7.6)^{34}$. Then the primary antiserum, a rabbit polyclonal antibody $(\mathrm{NCL}-\mathrm{pS} 2$, Novacastra Laboratories Ltd. (Sanbio)) was applied to the sections at a 1:400 dilution. Nonspecific binding of the antibody was blocked with $5 \%$ bovine serum albumin (BSA, Ria Grade, Sigma) in phosphate buffered saline (PBS, $\mathrm{pH}=7.4$ ). Then the primary antibody was applied to the tumour sections. Excessive amounts of the antibody were washed away in PBS. The avidin-biotin-peroxidase complex (Vectastain ABC Kit, Vector Laboratories, CA, USA) method was used to obtain amplification of the primary antigen-antibody bindings ${ }^{35}$. These bindings were highlighted with DAB (di-amino-benzidin, Signma). Finally counterstaining with hematoxylin completed the procedure.

The percentage of breast cancer cells showing a positive immunohistochemical reaction in a representative section of each tumour was cletermined by counting the number of stained cells in 500 cancer cells. The results were then classified into the following groups, comparable to previous described classifications ${ }^{27.2 R}$ : 0 if staining was negative, 1 if $1-10 \%$ of the cancer cells showed positive staining, 2 if $11-20 \%$ of the cancer cells showed positive staining and 3 if more than $20 \%$ of the cancer cells were positively stained.

\section{Flow cytometric evaluation of ploidy status and S-phase fraction}

Flow cytometric determination of DNA levels was performed in nuclei isolated from paraffin-embedded tissue ${ }^{36,37}$. Fifty $\mu \mathrm{m}$ sections were cut from formalin-fixed paraffin-embedded tissue blocks of the primary tumours. An adjacent $5 \mu \mathrm{m}$ section was cut for histological control. DNA content was measured by the method of Vindel $6{ }^{3 *}$. Tumours with a single $\mathrm{G}_{1}$ peak were considered to be diploid, whereas evidence of an additional peak indicated aneuploidy. DNA index (DI) was calculated as the ratio of aneuploid to diploid $G_{1} / 0$ peak level. Histograms with coefficients of variation less than $8 \%$ were considered of good quality. The 
proliferative activity (SPF) was calculated by counting the number of cells between the inclination points of the descending $G_{1}$ peak and the ascending $G_{2} / M_{\text {peak }}^{39.40}$. In cases of less than $30 \%$ admixture of diploid celss, the percentage of aneuploid $S$ phase cells was calculated without corrections for the presence of diploid S- and $\mathrm{G}_{2} / \mathrm{M}$-phase cells. In case of more than $30 \%$ admixture of diploid cells in overlap of diploid and hyperdiploid histograms the percentage of S-phase cells could not be calculated.

\section{Statistical Analysis}

Disease-free survival was defined as the time from the day of diagnosis till the time of first relapse, death or last follow-up.

Overall survival was defined as the time from the day of diagnosis till the day of death or last follow-up.

Statistical analysis was done using the statistical packages SAS (SAS Institute Inc., Cary, NC, USA) and S-plus (Statistical Sciences Europe, Oxford, UK). The association between the expression of pS2 and other possible prognostic factors was analyzed by the chi-square test. Curves for disease-free survival and overall survival were estimated by the Kaplan-Meier method. Differences were analyzed using the logrank test.

Finally, prognostic variables were included in a Cox regression analysis.

For further survival analysis all patients showing any degree of pS2-positivity were considered as one group, as no difference between pS2-positive subgroups was demonstrated.

\section{Results}

From the 339 patients $162(47.8 \%)$ were negative for pS2. In the $177 \mathrm{pS2}$-positive patients $(52.2 \%)$ the majority ( 140 patients $=41.3 \%$ ) showed staining in only 1 $10 \%$ of cells, while in 21 patients $(6.2 \%)$ staining was seen in $11-20 \%$ of cells and in 16 patients $(4.7 \%)$ in more than $20 \%$ of cells.

A significant association was found between $\mathrm{pS} 2$ expression and ER-status $(p<0.05)$, however, this was not found with $P R$. No relationship was demonstrated between pS2-positivity and age, histological type, tumour-size, S-phase fraction, ploidy status and axillary lymph node status (table II.I). 
Table II.1. Correlation between pS2 status and oher clinical. pathological and biologicas tactors.

\begin{tabular}{|c|c|c|c|}
\hline & pS2-negative & pS2-positive & p-value \\
\hline $\begin{array}{l}\mathrm{ER}(\mathrm{n}=328) \\
\leq 10 \mathrm{hmol} / \mathrm{mg} \text { protein } \\
>10 \mathrm{fmol} / \mathrm{mg} \text { protein }\end{array}$ & $\begin{array}{l}60 \\
97\end{array}$ & $\begin{array}{r}32 \\
139\end{array}$ & 0.0004 \\
\hline $\begin{aligned} \mathrm{PR}(\mathrm{n} & =263) \\
& \leq 10 \mathrm{fmol} / \mathrm{mg} \text { protein } \\
& >10 \mathrm{tmol} / \mathrm{mg} \text { protein }\end{aligned}$ & $\begin{array}{l}56 \\
63\end{array}$ & $\begin{array}{c}65 \\
79\end{array}$ & $\mathrm{NS}^{*}$ \\
\hline $\begin{array}{l}\text { Age }(n=339) \\
\leq 50 \text { years } \\
>50 \text { years }\end{array}$ & $\begin{array}{r}50 \\
112\end{array}$ & $\begin{array}{r}61 \\
116\end{array}$ & NS \\
\hline $\begin{array}{l}\text { Histological type }(\mathrm{n}=339) \\
\text { Juctal carcinoma } \\
\text { other types }\end{array}$ & $\begin{array}{r}120 \\
42\end{array}$ & $\begin{array}{r}130 \\
47\end{array}$ & NS \\
\hline $\begin{array}{l}\text { Tumour size }(\mathrm{n}=339) \\
T_{1} T_{3}, T_{3}, T_{4}\end{array}$ & $\begin{array}{l}71 \\
91\end{array}$ & $\begin{array}{l}78 \\
99\end{array}$ & NS \\
\hline $\begin{array}{l}\text { Node status }(n=322) \\
\text { nesative } \\
\text { positive }\end{array}$ & $\begin{array}{l}86 \\
66\end{array}$ & $\begin{array}{l}97 \\
73\end{array}$ & $\mathrm{NS}$ \\
\hline $\begin{array}{l}\mathrm{SPF}(\mathrm{n}=220) \\
\quad \leq 8.0 \\
\quad>8.0\end{array}$ & $\begin{array}{l}45 \\
55\end{array}$ & $\begin{array}{l}57 \\
63\end{array}$ & $N S$ \\
\hline $\begin{array}{l}\text { Ploidy status }(n=318) \\
\text { diploid } \\
\text { aneuploid }\end{array}$ & $\begin{array}{l}61 \\
92\end{array}$ & $\begin{array}{l}67 \\
98\end{array}$ & $\mathrm{NS}$ \\
\hline
\end{tabular}

$N S=$ not significant

No difference in both disease-free and overall survival for pS2-positive and pS2negative patients was found. This was the case for both the axillary node-positive and node-negative subgroups. Only when prognosticating the risk for locoregional recurrence there was a trend for better outcome in pS2-negative patients $(p=0.08$, see figure II.1). Looking at ER-positive and ER-negative subgroups the pS2-status also had no additional prognostic value with respect to disease-free and overall survival. We also have investigated the possible role of $\mathrm{pS} 2$ in predicting the response to adjuvant therapy with MPA. Such a rolle could not be demonstrated whereby it has to be kept in mind that the number of patients was small ( 30 patients in both groups). 


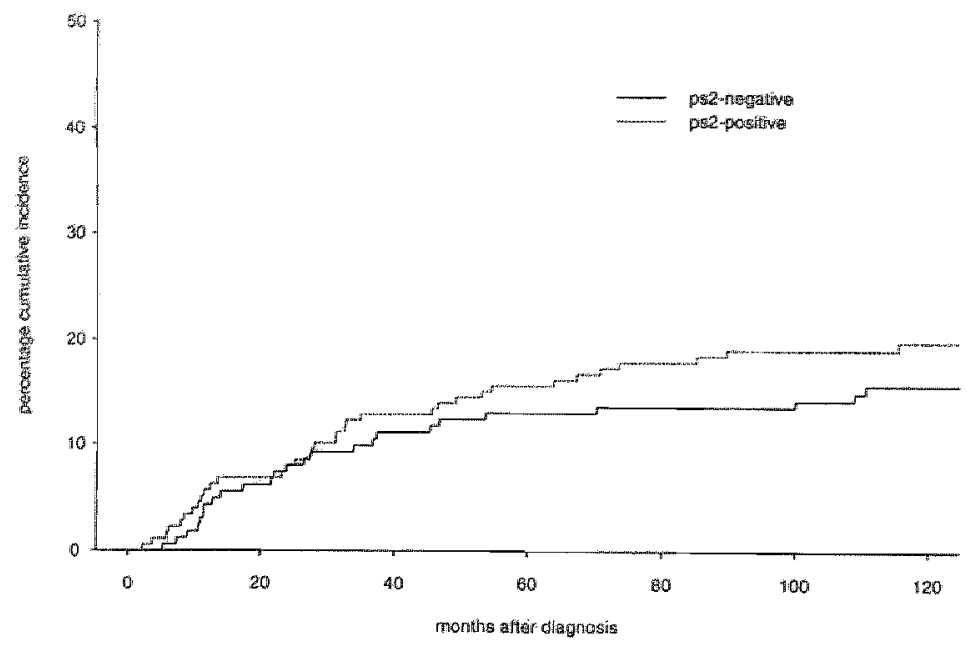

Figure II.1. Locoregional relapse specific cumulative incidence curves for $\mathrm{pS2}$-negative and pS2 positive patients $(\mathrm{p}=0.08)$

In pS2-positive patients the survival time after the first locoregional relapse and/or distant metastasis was found to be significantly longer than in pS2-negative patients $(\mathrm{p}=0.002$, see figure II.2). In a multivariate analysis including lymph node status, ER, PR, age, ploidy status and S-phase, pS2 positivity was the only predictive factor for postrelapse survival ( $p=0.006$, see table II.2). After excluding $p S 2$ from this multivariate analysis, ER showed a significant association with post-relapse survival $(p=0.04)$.

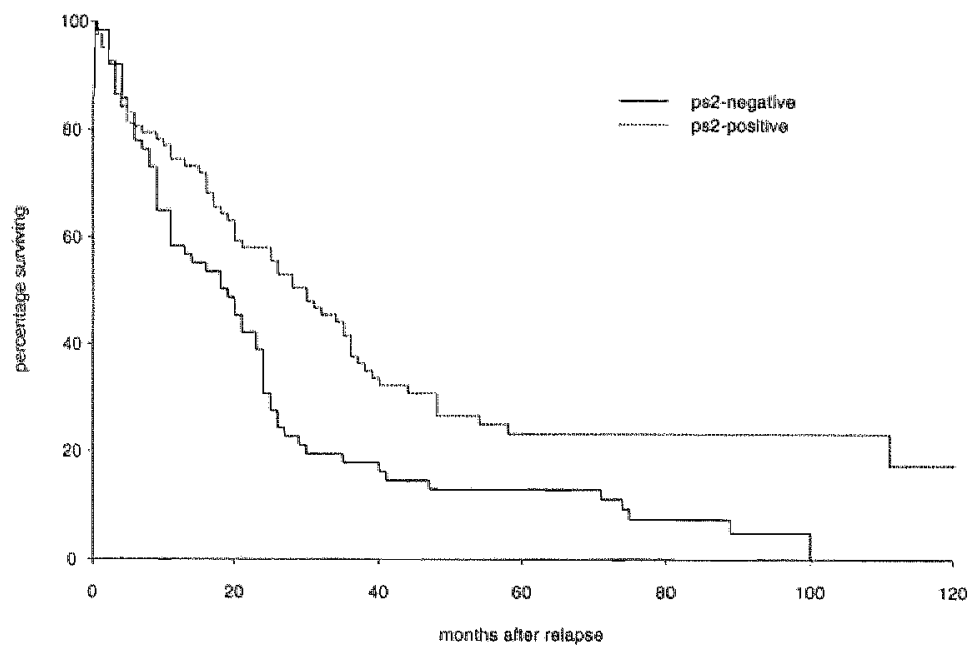

Figure 11.2 Survival after tirst relapse (locoregional and/or distant metastasis) for $\mathrm{p}$ S2-negative and pS2-positive patients $(p=0.002)$ 
Table 11.2. Cox multivariate analysis for post-relapse survival.

\begin{tabular}{lll}
\hline & RHR $^{\prime}$ & p-value \\
\hline PS2 (positive vs. negative) & 0.574 & 0.006 \\
Node status (negative vs positive) & 1.226 & 0.330 \\
ER ( $\leq 10$ ws $>10$ mol/mg protein) & 1.438 & 0.170 \\
PR ( $\leq 10$ vs $>10 f m o l$ mg protein) & 1.423 & 0.140 \\
Ploidy status (diploid vs aneuploid) & 1.171 & 0.510 \\
SPF $(\leq 8.0$ ws $>8.0 \%)$ & 0.664 & 0.120 \\
Age $(\leq 50$ ws $>50$ years) & 0.855 & 0.490 \\
\hline
\end{tabular}

relative hazard rate

\section{Discussion}

We have investigated the relationship between immunohistochemical pS2 expression and a number of other possible prognostic factors, and the possible influence of pS2 positivity on disease-free, overall and post-relapse survival, in patients with primary breast cancer.

This is the first study demonstrating a significant difference in post-relapse survival between $\mathrm{pS2}$-positive and pS2-negative patients, also in multivariate analysis. This probably implies that $\mathrm{pS} 2$ may be a predictive factor for response to systemic therapy, although this issue was not formally addressed in this study. The same has been found in two other studies in univariate analysi s $^{27.28}$. In one of these studies a significant difference was only found in the subgroup of patients treated by chemotherapy or local therapy ${ }^{27}$. Altogether the data suggest that $\mathrm{pS} 2$ is more a predictive than a prognostic factor, which has been supported by a study investigating the value of $\mathrm{p} S 2$ for predicting the response to tamoxifen therapy ${ }^{23}$.

Slightly more than half of the tumours were pS2-positive, which is in the range of 49-73\% reported in other studies that used immunohistochemical methods, although with slightly different cut-off points ${ }^{25,27,28}$.

In our study we have found an association of pS2 with ER-status, which is in accordance with all other studies ${ }^{19-29}$. However, in contrast to the other studies ${ }^{\text {ts }}$ 24.26-29 no association with PR status has been found. In an earlier study PR was also not a prognostic factor using a cutt-off point of $10 \mathrm{fmol} / \mathrm{mg}$ protein ${ }^{41}$.

Correlations between S-phase fraction and pS2 status have not been demonstrated in our study, neither between ploidy status and pS2 status. These correlations have not been investigated in the literature before. One study has reported a negative correlation between $\mathrm{pS} 2$ status and another proliferation marker ${ }^{26}$, the thymidine 
labelling index. Such a negative correlation seems, however, consistent with the fact that $\mathrm{p} \$ 2$-deficient mice develop large adenomas in the stomach by five months of age and in $30 \%$ even intra-epithelial and intramucosal carcinomas ${ }^{11}$. Whether pS2 has a comparable role in the development of breast cancer is unknown.

Data on the prognostic significance of $\mathrm{pS2}$ in breast cancer are certainly not consistent. We could not demonstrate a relation between pS2-status and disease-free or overall-survival. Also, no other study using the easier immunohistochemical method has found prognostic significance for $\mathrm{pS} 2$ status in multivariate anallysis ${ }^{25-28}$, although in univariate analysis this was sometimes demonstrated for node-negative patients $s^{25}$, for node-positive patients ${ }^{2 x}$ or for overall survival only $y^{27}$. Most studies have a median follow-up of at least 70 months ${ }^{25-2 x}$.

On the contrary the majority of studies using cytosol assays have found a better outcome for both disease-free and overall survival in patients with pS2-positive tumours even in mulivariate analysis ${ }^{19.22}$. However, in one study only a relation with overall survival has been demonstrated ${ }^{23}$, while in another study the prognostic significance of $\mathrm{pS} 2$ was lost in multivariate analysis ${ }^{24}$. Of importance is that the median follow-up in all these studies was 6 years at most.

It cannot be excluded that the prognostic significance of $\mathrm{pS} 2$ is time-dependent, although this is not very likely in view of the sometimes large differences in the studies using cytosolic assays. Probably cytosolic assays and immunohistochemical methods are measuring different aspects of these proteins. The immunohistochemical method is thereby easy to perform in a routine laboratory and not time-consuming in contrast to the cytosolic assay.

In conclusion, pS2 measured by immunohistochemistry has no role as a prognostic factor in breast cancer. However, $\mathrm{pS} 2$ is an independent prognostic factor for postrelapse survival. The most likely explanation for this phenomenon is that $\mathrm{pS} 2$ is a predictive factor for response to systemic therapy. 


\section{References}

1. Knight WOE III, Livingstone RB, Gregory EG, McGuire WL: Oestrogen-receptor as an independent prognostic factor for early recurrence in breast cancer. Cancer Res 1977; 37: 4669-4671.

2. Williams MR, Todd JH, Elis 10, Dowle CS. Haybitte JL, Elston CW. Nicholson RI. Griffiths K, Blamey RW: Oestrogen-receptors in primary and advanced breast cancer: an eight-year review of 704 cases. Br J Cancer 1987:55:67-73.

3. Fisher B, Redmond C, Fisher ER, Caplan R: Relative worth of estrogen and progesterone receptor and pathologic characteristics of diffenentiation as indicators of prognosis in node-negatiwe breast cancer patients: findings from National Surgical Adjuvant Breast and Bowel Protocol B-06. I Cin Oncol 1988; 6: 1076-1087.

4. Alexieva-Figusch J, wan Putten WL, Blankenstein MA, Blonk van der Wijst J, Klijn JG: The prognostic walue and relationships of patient characteristics, estrogen and progestin receptors, and site of relapse in primary breast cancer. Cancer 1988; 61: $758-768$.

5. Clark GM, McGuire WL: Steroid receptors and other prognostic hactors in primary breasit cancer. Semin Oncol 1988; 15 (supp): 20-25.

6. Molino A, Turazza M, Bonetti A, Biondani P, Griso C. Adami L, Corgnati A, Nortilli R, Pollini GP, Modena S: Estrogen and progesterone receptors in breast cancer: correlation with clinical and pathological features and with prognosis. Oncology 1992; 49: 82-88.

7. Mason BH. Holdaway IM, Mullins PR, Yee LH, Kay RG: Progesterone and estrogen receptors as prognostic variables in breast cancer. Cancer Res 1983; 43: $2985-2990$.

8. MoGuire WL, Tandon AK, Allred DC, Chamness GC, Clark GM: How to use prognostic factors in axillary node-negative breast cancer patients. I Natl Cancer Inst 1990; $82: 1006-1015$.

9. Sigurdsson H, Baldetorp B. Borg A, Daberg M, Feno M, Killander D, Olsson H: Indicators of prognosis in node-negative breast cancer, N Engl J Med 1990; 322: 1045-1053,

10. Masiakowski P, Breathnach R, Bloch J, Gannon F, Krust A, Chambon P: Cloning of CDNA sequences of hormone-regulated genes from the MCF-7 human breast cancer cell line. Nucleic Acids Res 1982; 10; 7895-7903.

11. Plaut AG: Trefoil peptides in the defense of the gastrointestinal tract. New Engl I Med 1997; 336:506-507.

12. Poulsom R: Trefoil peptides. Baillières Clin Gastroenterol 1996; 10:113-134.

13. Theisinger $B$, Welter $C$, Seirz G, Rio MC, Lathe R, Chambon P, Blin $N$ : Expression of the breast cancer associated gene pS2 and the pancreanic spasmolytic polypeptide gene (hSP) in diffuse type of stomach carcinoma. Eur J Cancer 1991; 27: $770-773$. 
14. Seitz G, Theisinger B, Tomasetto C, Rio MC, Chambon P. Blin N, Welter C: Breast cancer associated protein $\mathrm{p} S 2$ expression in tumors of the biliary tract. Amer J Gastroenterol 1991; 86: 1491 1494.

15. Welter $\mathrm{C}$, Theisinger $\mathrm{B}$, Seitz $\mathrm{G}$, Tomasetto $\mathrm{C}$, Rio $\mathrm{MC}$, Chambon $\mathrm{P}$, Blin $\mathbb{N}$ : Association of the human spasmolytic polypeptide and an estrogen-induced breast cancer protein ( $\$ 2$ ) with human panureatic carcinoma. Lab Invest 1992; 66: $187-192$.

16. Welter C, Theisinger B, Rio MC, Seitz G, Schuder G, Blin N: Expression pattern of breast cancer associated protein $\mathrm{pS} 2 / \mathrm{BCE}$ in colorectal tumors. Int I Cancer $1994 ; 56: 52-55$.

17. Hăhnel $\mathbb{E}$, Robbins P. Hahnel $R$ : Expression of the pS2 gene in normal breast uissue. Breast Cancer Res Treat 1993; 28: 295-297.

18. Rio MC, Bellocq JP. Gairard B, Rasmussen UB, Krust A, Koehl C, Calderoli $\mathbb{H}$, Schift $V$, Renaud $R$, Chambon P: Specific expression of the $\mathrm{pS} 2$ gene in subclasses of breast cancers in comparison with expression of the estrogen and progesterone receptors and the oncogene ERBB2. Proc Natl Acad Sci 1987; 84: 9243-9247.

19. Foekens JA, Rio MC. Seguin P, van Putten WLJ, Fauque I, Nap M, Klijn JGM, Chambon P: Prediction of relapse and survival in breast cancer patients by $\mathrm{pS} 2$ protein status. Cancer Res 1990; 50: 3832-3837.

20. Predine J, Spyratos F, Prud'homme JF, Andrieu C, Hacene K, Brunet M, Pallud C. Milgrom E: Enzyme-linked immunosorbent assay of pS2 in breast cancers, benign tumors and normal breast tissues. Cancer $1992 ; 69: 2116-2123$.

21. Foekens JA, van Putten WLJ, Portengen H, de Koning HYWCM, Thirion B, Alexieva-Figusch J, Klijn JGM: Prognostic value of $\mathrm{pS2}$ and cathepsin $\mathrm{D}$ in 710 primary breast tumors: multivariate analysis. J Clin Oncol 1993; 1 1: 899-908.

22. Gion M, Mione R, Papagallo R, Gatti C, Nascimben O, Bari M, Leon AE, Vinante O, Bruscagnin G: PS2 in breast cancer - alternative or complementary tool to steriod receptor status? Evaluation of 446 cases. Br J Cancer 1993; 68: 374-379.

23. Spyratos F, Andrieu MC, Hacene K. Chambon P. Rio MC; PS2 and response to adjuvan hormone therapy in primary breast cancer. Br J Cancer 1994: 69: 394-397.

24. Speiser P. Stolzlechner J, Haiden K, Heinzl H. Jakesz R, Pecherstorfer M, Rosen H. Sevelda P, Zeilliger R: PS2 protein status fails to be an independent prognostic factor in an average breast cancer population. Anticancer Research 1994; 14: 2125 2130.

25. Thor AD, Koerner FC, Edgerton SM, Wood WC, Stacher MA, Schwartz LH: PS2 expression in primary breast carcinomas: relationship to clinical and histological Ceatures and survival. Breast Cancer Res Treat 1992; 21: 111-119.

26. Cappelletti V. Coradini D, Scanziani E, Benini E, Silvestrini R, Di Fronzo G: Prognostic relevance of $\mathrm{pS} 2$ status in association with steroid receptor status and proliferative activity in node-negative breast cancer. Eur $₫$ Cancer 1992; 28A: $1315-1318$.

27. Soubeyran I, Wafflart J, Bonichon F, de Mascarel I, Trojani M, Durand M, Avril A. Coindre JM: Immunohistochemical determination of $\mathrm{pS2}$ in invasive breast carcinomas: a study on 942 cases. Breast Cancer Res Treat 1995; 34: 119-128. 
28. Horiguchi $J$. Iino $Y$, Takei $H$ : Expression of pS2 estrogen-inducible protein in primary breast cancer. Oncology 1996; $53: 12-15$.

29. Foekens JA, Portengen H, Look MP, van Putten WLI, Thirion M, Bontenbal M, Khin JGM: Relarionship of $\mathrm{PS} 2$ with response to tamoxifen therapy in patients with recurrent breast cancer. Br J Cancer 1994: 70: 1217-1223.

30. Staging for carcinoma of the breast. In: Beahrs O, Henson D. Hutler R, Myers M. eds. Manual for staging of cancer, 3rd ed. Pliladelphia, JB Lippincot, 1988; $145-150$.

31. Hupperets PSGJ, Wils J, Volovics L, Schouten LJ, Fickers M. Bron H. Schouten H, Jager J, Smees J, de Jong J, Blijham GH: Adjuvant chemohomonal therapy with cyclophosphamide, doxorubicin and 5-fuorouracil (CAF) wilh or without medroxyprogesterone acetate for node-positive breast cancer patients. Am Onool 1993: 4: 295-301.

32. Hupperets P, Wils J, Volovics L. Schouten LJ, Fickers M, Bron H, Schouten H, Jager J, de Jong J, Blijham GH: Adjuvant chemohormonal therapy with cyclophosphamide, doxorubicin and 5-fluorouracil (CAF) with or without medroxyprogesterone acetate for node-positive breast cancer patients. Update all 7 years follow-up. Ann Oncol 1995:6:90-91.

33. Scatchard G. The attraction of proteins from small molecules and ions. Ann NY Ac Sci 1949; $51: 660-672$.

34. Henry JA, Piggott NH, Mallick UK, Nicholson S, Farndon JR, Westley BR, May FEB: pNR-2/pS2 immunohistochemical staining in breast cancer: corretation with prognostic factors and endocrine response. $\mathrm{Br} J$ Cancer 1991; 63: 615-622.

35. Guesden JL, Termynck T, Avreamas S: The use of avidin biotin interaction in immunoenzymatic techniques. J Histochem Cytochem 1979; 27: 1131-1139.

36. Hedley DW: Flow cytometry using paraffin-embedded tissue: five years on. Cytometry 1989; 10:229-241.

37. Schutte B, Reynders MMJ, Bosman FTG, Blijham GH: Flow cytomentic determination of DNA ploidy level in isolated nuclei from parafin embedded risue. Cytometry 1986; 6:26-30.

38. Vindelov LL, Christensen U, Nissen NI: A detergent trypsin method for die preparation of nuclei for flow cytometric DNA analysis. Cytometry 1984: 5 : $408-419$

39. Lowry OH, Rosebrowgh NJ, Farr AL and Randall RJ: Protein measurement will the folim phenol reagent. I Biol Chem 1951; 193: 265-275.

40. Hiddemann W, Schumann J, Andreel M, Barlogie B, Herman Cl, Leif RC, Mayall BH, Murphy RF. Sandberg AA: Convention of nomenclature for DNA cytometry. Cancer Genet Cyogenet 1984; 13:181-183.

41. Hupperets PSGJ, Volovics L, Schouten L, Jager J, Schouten HC, Hillen HFP. Bligham GH: The prognostic significance of steroid receptor activity in tumor tissues of patients with primary breast cancer. Am J Clin Oncol 1997; 20:546 551 . 


\section{Chapter III}

\section{CD44v6 is not a prognostic factor in primary breast cancer}

RLH Jansen, SR Joosten-Achjanie, JW Arends, A Volovics, PSGJ Hupperets, HC Schouten, HFP Hillen

Annals of Oncology 1998; 9: 109-111 


\section{Summary}

\section{Mackground}

CD44 is an adhesion molecule and represents a highly variable family of isoforms. The isoform CD44v6 has been associated with metastasis formation and poor prognosis in animal models and human colon cancer. Resuls of studies in primary breast cancer are relatively small and contradictory.

\section{Patients and Methods}

The immunohistochemical expression of CD44v6 was studied in a series of 338 patients with primary breast tumours, uniformly staged and treated in a single center with a long median follow-up of 128 months. The prognostic significance of CD44v6 as well as the correlation with several chnicopathological features were analysed.

\section{Results}

Two hundred nineteen of $338(64.8 \%)$ of the breast cancers were CD44v6-positive ( $>5 \%$ of tumour cells with positive staining). CD44w6 expression had no value for prognosticating disease-free or overall survival at this or any other cut-off point.

\section{Conclusion}

CD44v6 expression is not a prognostic factor in primary breast cancer. 


\section{Introduction}

The hyaluronate receptor CD44 is an adhesion molecule and represents a highly variable family of isoforms, with putative functions in development, somatic cell functions and metastatic disease $e^{\prime}$ Many variant isoforms exist characterized by the insertion of additional amino acids in the extracellular domain of the protein (CD44v1-CD44v10) $)^{2.3}$. Isoforms containing the exon $v 6$ encoded domains seem to promote tumour dissemination in rat pancreas carcinoma ${ }^{4}$ and have been associated with poor prognosis in human colon carcinoma". The furst study on the prognostic value of CD44v6 in 100 patients with primary breast cancer has shown it to be an independent prognostic marker. This result could not be confirmed in a second study with 108 node-negative and 119 node-positive patients ${ }^{2}$. Discrepancy could be due to the different patient numbers and relatively short follow-up. Therefore, we have performed a study on the possible use of CD44v6 as a prognostic factor in a large group of 338 patients with primary breast cancer and a median follow-up of more than 10 years.

\section{Patients and Methods}

\section{Patients}

In the period May 1982-August 1987 the 338 patients were treated for primary breast cancer in the University Hospital Maastricht. All patients were staged at the time of diagnosis according to the TNM classification. The median age was 57 years (range $25-87$ years). Two hundred eighteen patients (64.5\%) had undergone a modified radical mastectomy, 97 patients $(28.7 \%)$ a lumpectomy with axillary lymph node dissection, whereas in 23 patients $(6.8 \%)$ only a biopsy was done either because of $T_{4}$ stage or high age, in 4 patients with an axillary lymph node dissection. One hundred eighty-three patients (54.2\%) had no axillary lymph node metastases, 136 patients $(40.2 \%)$ had metastasis in one or more axillary lymph nodes, while in 19 patients $(5.6 \%)$ the axillary lymph node status was unknown. Axillary lymph node-positive patients younger than 70 years were treated with adjuvant chemotherapy consisting of 5-fluorouracil, adriamycin and cyclophosphamide. If they agreed to participate in a multicenter clinical trial, they were randomized for concomitant treatment with medroxyprogesterone acetate (MPA) or no MPA. The results of this clinical trial have been described more in detail elsewhere. The median follow-up was 128 months (range 61-170 months). One hundred forty-six patients experienced a relapse; 44 had a locoregionall relapse, 86 distant metastases and 16 patients both simultaneously at the moment of first relapse. 


\section{Methods}

\section{Steroid receptors}

The oestrogen-receptor (ER) and progesterone-receptor (PR) assays were all performed on histologically proven breast cancer tissues using the dextran-coated charcoal method with multiple-point scatchard-plot analysis.

For all the assays the minimum cytosol protein concentration was $2 \mathrm{mg} / \mathrm{ml}$ cytosol. PR status was determined only in patients entered from August $\mathbb{1 9 8 3}(\mathrm{n}=261)$.

\section{Immunohistochemistry}

Three wn sections were cut from routinely formalin-fixed and paraffin-embedded archival tumour blocks. Inmunohistochemical staining was performed using the mouse monoclonal antibody against. CD44v6 (R\&D Systems, Abingdon, UK; 1:1000, one hour, room temperature). Microwave antigen retrieval with citric buffer $(\mathrm{ph}=6.0$ ) was administered. The three-stage avidin-biotin-peroxidase complex method was used (Vectastain ABC Kit, Vector Laboratories, CA, USA).

The antibodies were diluted in PBS containing $0.5 \%$ BSA. The staining was highlighted with DAB (di-amino-benzidin, SIGMA) and counterstained with hematoxylin. If more than $5 \%$ of iumour cells showed CD $44 v 6$ expression, the tumour was considered CD44v6-positive. At least 1000 tumour cells were counted. However, also other cut-off points as well as the intensity of staining in combination with a cut-off of $5 \%$ positive tumour cells were analysed ${ }^{\text {b. }_{0}}$.

For other immunohistochemical staining procedures the mouse monoclonal antibody MIB-I (Dianova, Hamburg, Germany; 1:100, one hour incubation at room temperature) and rabbit polyclonal antibody NCL-pS2 (Novacastra Laboratories Ltd. Sanbio, Newcastle, UK; 1:400, one hour incubation at room temperature) were used. Antigen unmasking by microwave antigen retrieval was necessary for MIB-I staining. Tumours were considered pS2-positive in the case of $\geq 1 \%$ of umour cells staining.

\section{Flow cytometric evaluation of ploidy status and S-phase fraction}

Flow cytometric evaluation of ploidy status and $S$-phase fraction was done as described previously".

\section{Statistical Analysis}

Disease-free survival was defined as the time from the day of diagnosis till the time of first relapse, death or last follow-up.

Overall survival was defined as the time from the day of diagnosis till the day of death or last follow-up. 
Statistical analysis was done using the statistical packages SAS (SAS Institute Inc. Cary, NC, USA) and S-plus (Statistical Sciences Europe, Oxford, UK). The association between the expression of CD44v6 and other possible prognostic factors was analyzed by the chi-square test. Curves for disease-free survival and overall survival were estimated by the Kaplan-Meier method. Differences were analyzed using the logrank test.

\section{Results}

CD $44 \times 6$ staining was membraneous, and mostly heterogeneous. Staining was seen in $0-100 \%$ (median 13\%) of tumour cells. In most cases moderate to strong staining intensity was seen. With a cut-off point of $5 \% 219$ of $338(64.8 \%)$ of turnours were positive. CD44v6 expression was associated with smaller tumour size $(p<0.01)$ and the absence of axillary lymph node metastases $(p<0.001)$ (table III. 1). No correlation could be demonstrated with ER, PR, histology, p\$2, S-phase fraction, ploidy, MIB-1, and age (table III.1). In univariate analysis CD44v6positivity did not influence the disease-free survival $(p=0.19)$ (Figure III. 1). Also no correlation with overall survival was demonstrated. Furthermore, looking at node-positive and node-negative subgroups no difference in disease-free or overall survival was found between CD44v6-positive and negative patients. When CD44v6 was analyzed as a continous variable, then it showed no risk differentiation at any cut-off point both for disease-free and overall survival. When staining intensity was taken into account (positive $=>5 \%$ positive tumour cells and at least moderate staining) the association with nodal status was only borderline $(p=0.06)$ and the association with $\mathrm{T}$ stage was lost. With this cut-off point also no difference between CD44v6-positive and CD44v6-negative patients was seen in discase-free and overall survival. Furthermore, CD44v6 did not influence post-relapse survival.

\section{Discussion}

Our results do not confirm the results of the first published studly on the prognostic value of $\mathrm{CD} 44 \mathrm{v} 6^{\circ}$. These first data have, however, been questioned for several reasons, e.g. small numbers of patients, relatively short follow-up and the use of a polyclonal antibody ${ }^{10}$. The results of our study are, however, quite similar to those of another quite large study with 227 patients $^{7}$. In this study $56 \%$ of breast cancers were CD44v6-positive and as in our study a sightly better disease-free survival has been found for CD44v6-positive patients although this thend did not reach statistical significance?. A smaller study has also not been able to demonstrate a prognostic value for $\mathrm{CD} 44 \mathrm{v} 6^{31}$ while another reports a prognostic impact only in univariate 
analysis ${ }^{12}$. In the published studies quite different cut-off points are used, varying from all positive staining" to a multiplication of percentage positive cells and staining intensity ${ }^{13}$ or only strong and/or widespread staining". Furthermore, different antibodies were used. These facts could explain the varying results with respect to the prognostic value of CD44v6. We have also looked at CD44v6 as a continuous variable, but we were not able to demonsirate a prognostic significance with any cut-off point for both disease-free and overall survival, using a specific monoclonal antibody.

Besides the results of our and several other studies the fact that CD44v6 is often expressed in normal tissues ${ }^{14}$ including normal breast tissue ${ }^{7.13 .14}$ argue against an important rolle of CD44. 6 in metastasis formation.

The expression of CD44 isoforms in tumour cells is much more complicated than simple the expression of a metastasis promoting factor. Isoforms of CD44 have different functions, and possibly different ligands depending on the microenviromment. As suggested recently the measurement of specific ligand binding may be more informative than the single determination of CD44 isoform expression to elucidate the role of CD44 in the progression of cancer ${ }^{\text {is }}$.

So in conclusion, despite the important role of CD44v6 in an animal model system, the results of this as well as most other smaller studies make it unlikely that CD44v6 is an important prognostic factor in breast cancer.

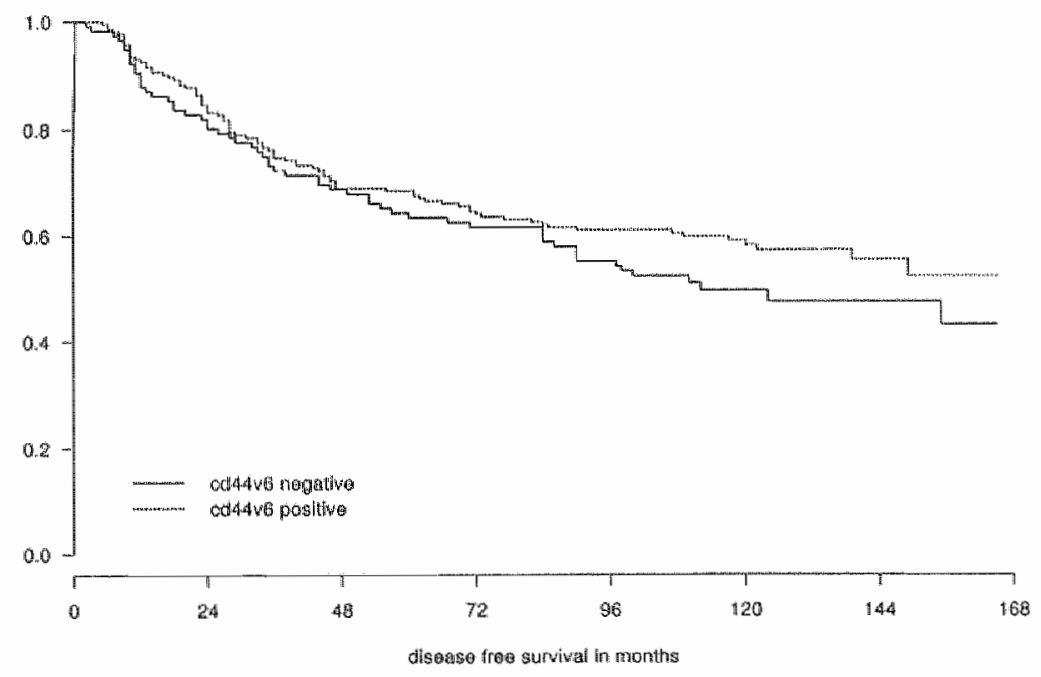

Figure III.1 Disease-free survival curves for the CD44positive ( $>5 \%$ staining) and CD44negative ( $55 \%$ staining) patients 
Table MII. Correlation beween CD44v6 and other prognostic factors

\begin{tabular}{|c|c|c|c|c|}
\hline & CD44 megative & CD44 positive ${ }^{2}$ & or (number) & $p$-value \\
\hline $\mathrm{ER} \leq 10$ fmol/mg protein & 36 & 59 & 327 & 0.46 \\
\hline $\mathrm{ER}>10 \mathrm{~mol} / \mathrm{mg}$ protem & 78 & 154 & & \\
\hline $\mathrm{PR} \leq 10 \mathrm{fmol} / \mathrm{mg}$ protein & 45 & 76 & 261 & 0.62 \\
\hline $\mathrm{PR}>10 \mathrm{fmol} / \mathrm{mg}$ protein & 48 & 92 & & \\
\hline Ductal carcinoma & 93 & 159 & 338 & 0.26 \\
\hline Other histological types & 26 & 60 & & \\
\hline Tumour size: $\quad T=1$ & 40 & 107 & 338 & 0.007 \\
\hline$T>1$ & 79 & 112 & & \\
\hline Axillary node-negative & 47 & 136 & 319 & $<0.001$ \\
\hline Axillary node positive & 67 & 69 & & \\
\hline pS2 negative & 59 & 99 & 329 & 0.34 \\
\hline p52 positive & 56 & 115 & & \\
\hline $\mathrm{MIB}-1>7 \%$ & 63 & 97 & 335 & 0.12 \\
\hline $\mathrm{M} I \mathrm{~B}-1 \leq 7 \%$ & 55 & 120 & & \\
\hline S-phase fraction $>8 \%$ & 37 & 84 & 220 & 0.93 \\
\hline S-phase fraction $\leq 8 \%$ & 32 & 67 & & \\
\hline Diploid & 38 & 88 & 317 & 0.14 \\
\hline Aneuploid & 73 & 118 & & \\
\hline Age $>50$ years & 34 & 78 & 338 & 0.19 \\
\hline Age $\leq 50$ years & 85 & 141 & & \\
\hline
\end{tabular}

${ }^{1} \leq 5 \%$ of tumour cells with positive staining; ${ }^{2}>5 \%$ of tumbur cells with positive staning 


\section{References}

1. Sleeman 1. Moll J, Sherman L er al. The role of CD44 splice variants in human metastatic cancer. Ciba Foundation Symp 1995; 189: 142-56.

2. Screaton GR, Bell MV, Jackson DG et al. Genomic structure of DNA encoding the lymphocyte homing receptor CD44 reveals at least 12 alternatively spliced exons. Proc Nat Acad Sci USA 1992; 89; 12160 64.

3. Tölg $C$, Hofmann $M$, Herrlich $P$, Ponta H. Splicing choice from ten variant exons establishes CD44 varability. Nucleic Acids Res 1993; $21: 1225-9$.

4. Günhert U, Hofmann M, Rudy W et al. A new variant of glycoprotein CD44 contars metastatic potential to rat carcinoma cells. Cell 1991; 65: 13-24.

5. Mulder JWR, Kruyi PM, Sewnath $M$ el al. Colorectal cancer prognosis and expression of exon-V6-containing CD44 proteins. Lancet $1994 ; 344: 1470-72$.

6. Kaufmann M, Heider KH, Sinn HP et al. CD44 variant exon epitopes in primary breast cancer and length of survival. Lancet 1995; 345:615-19.

7. Friedrichs $K$. Franke F, Lisboa BW et al. CD44 isoforms correlate with cellular differentiation but not with prognosis in human breast cancer. Cancer Res 1995; 55: $5424-33$.

8. Hupperets PSGJ, Wils J, Volovics L et al. Adjuvant chemohormonal therapy with cyclophosphamide, doxorubicin, and 5-fluorouracil (CAF) with or without medroxyprogesterone acetate for node-positive breast cancer patients. Ann Oncol $1993 ; 4: 295-301$.

9. Hupperets P. Wils I, Volovics I. et al. Adjuvant homonal therapy with cyclophosphamide, doxorubicin and 5-fluorouracil (CAF) with or without medroxyprogesterone acetate for node-positive breast cancer patients: update at 7 years follow-up. Ann Oncol 1995; 6: 90-1.

10. Friedrichs $K$, Kugler $G$, Franke F et al. CD44 isotorms in prognosis of breast cancer. Lancet (Letter) 1995:345: 1237.

11. Schumacher U, Hony HP, Horst HA et al, A CD44 variant exon 6 epitope as a prognostic indicator in breast cancer. Eur I Surg Oncol 1996; 22: 259-61.

12. Tempfer C. Losch A. Heinzl Het al. Prognostic value of immunohistochemically detected CD44 isoforms CD44v5, CD44v6 and CD44v7 8 in human breast cancer. Eur J Cancer 1996: 32A: 2023-25.

13. Regidor PA, Callies R. Regidor $M$ et al. Expression of the CD44 variant isoforms 6 and $4 / 5$ in breast cancer - correlation with established prognostic parameters. Arch Gynecol Obstet 1996:258: 125-35.

14. Fox SB, Fawcet I, Jackson DG et al Normal human tissues, in addition to some tumors, express multiple CD44 isoforms. Cancer Res 1994; 54: 4539-46.

15. Mau-Sun S. Mori H, Liu D. CD44 as a marker in human cancer. Curr Opin Oncol 1997:9:108-12. 


\section{Chapter IV}

\section{MIB-1 labelling index is an independent prognostic marker in primary breast cancer}

RLH Jansen, PSGJ Hupperets, JW Arends, SR Joosten-Achjanie, A Volovics, HC Schouten, HFP Hillen

British Journal of Cancer 1998; 78: 460-465 


\section{Summary}

The proliferative activity of a tumour is considered to be an important prognostic factor in primary breast cancer. We have investigated the prognostic value of the MIB-1 labelling index in 341 patients with primary breast cancer and compared the results with the Sphase fraction in 220 patients of the same cohort. All patients were treated in one hospital and had a median follow-up of 128 months. No correlation between MIB-1 labelling and S-phase fraction could be demonstrated. MIB-I had prognostic value for disease-free survival in the whole group of patients $(p<0.001)$ and in the node-negative subgroup $(p<0.001)$. In mullivariate analysis $\mathrm{MIB}-1$ was an independent prognostic factor $(p=0.004)$ besides axillary lymph node status $(p=0.001)$. In univariate analysis high $S$ phase fraction was associated with decreased overall survival $(p=0.04)$; however, not in multivariate analysis. Moreover, S-phase fraction had a borderline prognostic significance for post-relapse survival in multivariate analysis $(p=0.08)$. Thus, in conclusion the growth fraction of a tumour as determined by the MIB 4 labelling index is an important prognostic factor in patients with primary breast cancer. 


\section{Introduction}

In primary breast cancer the axillary lymph node status is still the most important prognostic factor and is used for deciding on adjuvant treatment. However, an axillary lymph node dissection itself has no or at best a very limited influence on disease-free survival and it causes substantial morbidity ${ }^{1.2}$. Moreover, the prognostic value of the axillary lymph node status is not absolute, as $30 \%$ of nodenegative patients die within 10 years because of recurrent disease and $30 \%$ of nodepositive patients survive 10 years without disease. Therefore, routine axillary lymph node dissection has recently become a matter of debate $e^{2}$ and search for other factors to identify patients at high risk of (early) relapse is thus needed. Many prognostic factors have been investigated, but so far no single factor or combination of factors can be used for treatment decisions in an individual patient. The proliferative activity of a tumour is, however, an important prognostic factor known to have an inverse relationship with the survival of patients with breast cancer. It can be measured by different methods, which all have their own advantages and disadavantages.

First, counting the number of mitoses in a hematoxylin- and eosin-stained slide is still an inexpensive method for the assessment of tumour cell proliferation. The mitotic index (MI) may be reproducible as shown in one study ${ }^{4}$, but there is no general agreement on this. The independent prognostic value of the MI has been shown in a few studies 5 .

Second the thymidine labelling index (TLI), reflecting the proliferative activity, has been claimed to be a strong and independent prognostic factor ${ }^{6.7}$. However, like the bromodeoxyuridine labelling index, viable tissue is needed, which make these methods hard to apply in a routine setting.

Third, DNA llow cytometry can be used to measure the percentage of cells in the S-phase in the cell cycle. In 1992 the DNA Cytometry Consensus Conference concluded that the literature supported a clear association between high $S$-phase fraction and an increased risk of recurrence and mortality for both axillary nodenegative and node-positive breast cancer patients. A disadvantage of this technique, however, is that tumour heterogeneity cannot be assessed, and 10-20\% of specimens are not evaluable because of a large coefficient of variation or admixture of stromal cells.

Finally, in the evaluation of proliferative activity there are also immunohistochemical methods using antibodies directed against nuclear antigens expressed during the cell cycle. Mainly applied is the Ki-67 antibody which binds to a large, nonhistone nuclear protein that is expressed in the late $G_{1}, S, G_{2}$ and $M$ phase of the cell cycle. Originally the antibody could only be used on fresh or frozen sections. More recently monoclonal antibodies such as MIB-1, raised against parts of Ki-67 antigen, have become avalable that can be used on formalin-fixed and routinely 
processed archival tissue. Several studies have shown a close correlation between the Ki-67 results on frozen sections and the MIB-1 findings on paraffin sections ${ }^{4-11}$, but the prognostic walue of both antibodies is not necessarily the same. Many studies have been performed using Ki-67 in breast cancer and at least 9 of these studies reported on correlations between $\mathrm{Ki}-67$ and disease-free survival (DFS) and/or overall survival (OS) $)^{2 \cdot 19}$. Seven of these studies demonstrated significant difference with respect to prognosis in patients with high and low Ki-67 labelling ${ }^{12-16,1920}$. However, follow-up was mostly short and, in addition, in only four of these studies multivariate analyses has been performed ${ }^{14.15,17.20}$. Three of these studies showed significant correlations between high Ki-67 labelling and shorter disease-free survival ${ }^{14.15 .20}$.

Fewer studies have been performed with the MIB-1 antibody. In general, the MIB1 inder also seems to be a prognostic factor sometimes even in multivariate analyses, but follow-up is generally rather short and/or the number of patients is low $11,21 \cdot 24$.

Not many studies have been performed comparing the different methods of assessing the proliferative activity of a tumour. Because immunohistochemical methods seem most suitable in a routine setting, we investigated MIB-1 immunoreactivity in a group of 341 patients uniformly treated in one hospital with a median follow-up of 128 months, have compared the results with the $S$-phase fraction in 220 patients of the same cohort, and examined correlations with other clinicopathological factors previously studied by our group.

\section{Patients and Methods}

\section{Patients}

The 341 patients were treated at the University Hospital Maastricht in the period May 1982-August 1987. Patients were selected according to the following criveria: 1. primary unilateral breast cancer without distant metastases; 2 . no other primary tumour; 3 . histological material available. All patients were staged at the time of diagnosis according to the International Union Against Cancer TNM Classification. The median age was 57 years (range 25-87 years). A total of 220 patients $(64.5 \%)$ had undergone a modified radical mastectomy, 97 patients $(28.5 \%)$ a lumpectomy with axillary lymph node dissection and in 24 patients $(7.0 \%)$ onlly a biopsy was performed, either because of $\mathrm{T}_{4}$ stage or advanced age, in 4 patients wiih an axillary lymph node dissection. A total of 183 patients $(53.7 \%)$ had no axillary lymph node metastases, 138 patients $(40.4 \%)$ had metastases in one or more axillary lymph nodes, whereas in 20 patients $(5.9 \%)$ the axillary lymph node status was unknown. Axillary lymph node-positive patients 
younger than 70 years were treated with adjuvant chemotherapy consisting of 5 fluorouracil, adriamycin and cyclophosphamide. If they agreed to participate in a clinical trial, they were randomized for concomitant treatment with or without medroxyprogesterone acetate. The results of the clinical trial have been described elsewhere ${ }^{25.26}$. Axillary lymph node-negative patients received no adjuvant systemic therapy. The median follow-up of all patients was 128 months (range 61 170 months).

\section{Methods}

\section{Steroid-receptors}

The oestrogen receptor (ER) and progesterone receptor (PR) assays were all performed on histologically proven breast cancer tissues using the dextran-coated charcoal method with multiple-point scatchard-plot analysis.

For all the assays the minimum cytosol protein concentration was $2 \mathrm{mg} / \mathrm{ml}$ cytosol. PR status was determined only in patients entered from August 1983. Tumours with ER or PR $>10$ fmol/mg protein were considered ER-or PR-positive.

\section{Flow cytometric evaluation of ploidy status and S-phase fraction}

Flow cytometric determination of DNA levels was performed on nuclei isolated from paraffin-embedded tissue ${ }^{27.28}$. Sections $(50 \mu \mathrm{m})$ were cut from formalin-fixed paraffin-embedded tissue blocks of the primary tumours. An adjacent $5 \mu \mathrm{m}$ section was cut for histological control. DNA content was measured by the method of Vindel $6 \mathrm{v}^{29}$. Tumours with a single $\mathrm{G}_{1}$ peak were considered to be cliploid, whereas evidence of an additional peak indicated aneuploidy. DNA index (DI) was calculated as the ratio of aneuploid to diploid $G_{1} /$ peak level. Hislograms with coefficients of variation less than $8 \%$ were considered of good quality. The S-phase fraction (SPF) was calculated by counting the number of cells between the inclination points of the descending $G_{1}$ peak and the ascending $G_{2} / M$ peak ${ }^{3 /}$. In cases of less than $30 \%$ admixture of diploid cells, the percentage of aneuploid $S$-phase cells was calculated without corrections for the presence of diploid $S$ - and $\mathrm{G}_{2} / \mathrm{M}$-phase cells. In case of more than $30 \%$ admixure of diploid cells in overlap in diploid and hyperdiploid histograms the percentage of S-phase cells was not calculated. After descriptive analysis the cut-off levels for the proportion of $S$-phase cells were set at $\leq 8 \%$ and $>8 \%$ in order to define two groups, with low and high SPF respectively.

\section{Immunohistochemistry}

Staining was performed using the mouse monoclonal antibody MIB-1 (Dianova, 
Hamburg, Germany; $1: 100,1$ hour incubation at room temperature) and rabbit polyclonal antibody NCL-pS2 (Novocastra Laboratories Ltd, Sanbio, Newcastle, UK: 1:400, 1 hour incubation at room temperature). All antibodies were diluted in $0.5 \%$ BSA (bovine serum albumin, Sigma) containing PBS (phosphate buffered saline, $\mathrm{pH}=7.4$ ). To reach optimal staining results for MIB-1 antigen unmasking was necessary by microwave antigen retrieval with citric buffer $0.01 \mathrm{M}$, $\mathrm{pH}=6.0)^{31}$. All staining procedures were done using a standard method. In short: 3 um sections were cut from routinely formalin-fixed and paraffin-embedded archival tumour samples. The MIB-1 sections were incubated overnight in a $60^{\circ} \mathrm{C}$ oven on APS (3-aminopropyltrietoxysilane, Sigma) coated glass slides, to obtain optimal fixation. Deparaffinization in xylene and washes in $100 \%$ ethanol were followed by removing endogenous peroxidase in $0.3 \% \mathrm{H}_{2} \mathrm{O}_{2}$ containing methanol ( 30 minutes, room temperature). After washing away the excessive amount of methanol in demineralized water, the necessary antigen unmasking procedure was performed. Non-specific binding of the antibodies was blocked with $5 \%$ BSA containing PBS. Then, the primary antibodies were applied to the tumour sections. Excessive amounts of antibodies were washed away in PBS. The avidin-biotin-peroxidase complex (Vectastain ABC Kit, Vector Laboratories, CA, USA) method was used to obtain amplification of the primary antigen-antibody bindings. These bindings were highlighted with DAB (dimamino-benzidin, Sigma). Finally, counterstaining with hematoxylin completed the procedure.

The percentage of breast cancer cells showing a positive immunohistochemical reaction in a representative section of each tumour was determined by counting the number of positively stained cells in 1000 cancer cells for MIB- 1 and 500 tumour cells for $\mathrm{pS} 2$. For $\mathrm{pS} 2$ tumours were considered positive if at least $1 \%$ of tumour cells showed staining comparable to previously described classifications ${ }^{32}$.

\section{Statistical Analysis}

Disease-free survival was defined as the time from the day of diagnosis till the time of first relapse, death or last follow-up.

Overall survival was defined as the time from the day of diagnosis till the day of death or last follow-up.

Statistical analysis was performed using the statistical packages SAS (SAS Institute Inc., Cary, NC, USA) and S-plus (Statistical Sciences Europe, Oxford, UK). The association between the expression of MIB-1 and other possible prognostic factors was analyzed by the chi-square test. Curves for disease-free survival and overall survival were estimated by the Kaplan-Meier method. Differences were analyzed using the logrank test. Finally, prognostic variables were included in a Cox regression analysis. 


\section{Results}

\section{MIB-1 labelling index}

Of the 341 tumours $14(4.1 \%)$ showed less than $1 \%$ positive tumour cells. The distribution of the percentage of staining tumour cells was asymmetric (range 0$71 \%$; mean $11.0 \%$, median $7.0 \%$ ). The relationship between MIB-1 labelling index when dichotomized at the median value $(\leq 7 \%$ versus $>7 \%)$ and other clinical and histological variables is shown in table IV.1. High MIB-1 was associated with aneuploidy $(p=0.005)$, ER-negativity $(p<0.001)$, PR-negativity $(p=0.01)$, the presence of axillary lymph node metastases $(p<0.001)$ and larger tumour size $(p=0.02)$. MIB-1 staining showed no relation with age, histology or $\mathrm{pS} 2$ status. Concerning histology, however, all 9 tubular carcinomas had a low MIB-1 labelling index, while medullary carcinomas had a significantly higher MIB-1 labelling undex than ductal carcinomas $(\mathrm{p}<0.05)$. No correlation at all was shown between thigh MIB-1 and high S-phase fraction $(p=0.50)$, while the Pearson correlation coefficient was 0.15 . For diploid tumours the Pearson correlation coefficient was 0.09 and for aneuploid tumours 0.25 .

Table IV.1

Correlation between MIB-1 and other factors.

\begin{tabular}{|c|c|c|c|c|c|}
\hline & & MIIB-1 $\leq 7 \%$ & $\mathrm{MIB-1}>7 \%$ & numiber & $p$-value \\
\hline \multirow{2}{*}{\multicolumn{2}{|c|}{$\begin{array}{l}\mathrm{ER} \leq 10 \mathrm{fmol} / \mathrm{mg} \text { protein } \\
\mathrm{ER}>1.0 \mathrm{fmol} / \mathrm{mg} \text { protein }\end{array}$}} & 35 & 60 & 330 & $<0.001$ \\
\hline & & 134 & 101 & & \\
\hline \multirow{2}{*}{\multicolumn{2}{|c|}{$\begin{array}{l}\mathrm{PR} \leq 10 \text { fmol/mg protein } \\
\mathrm{PR}>10 \mathrm{fmol} / \mathrm{mg} \text { protein }\end{array}$}} & 55 & 67 & 264 & 0.01 \\
\hline & & 86 & 56 & & \\
\hline \multirow{2}{*}{\multicolumn{2}{|c|}{ Age $\leq 50$ years }} & 59 & 52 & 341 & 0.74 \\
\hline & & 118 & 112 & & \\
\hline \multirow{2}{*}{\multicolumn{2}{|c|}{$\begin{array}{l}\text { Ductal carcinoma } \\
\text { Other histological types }\end{array}$}} & 126 & 127 & 341 & 0.18 \\
\hline & & 51 & 37 & & \\
\hline \multicolumn{2}{|l|}{ Node-negative } & 111 & 72 & 321 & $<0.001$ \\
\hline \multicolumn{2}{|l|}{ Node-positive } & 57 & 81 & & \\
\hline \multirow[t]{2}{*}{ Tumour size: } & $\mathrm{T}=1$ & 88 & 61 & 341 & 0.02 \\
\hline & $\pi>1$ & 89 & 103 & & \\
\hline \multirow{2}{*}{\multicolumn{2}{|c|}{$\begin{array}{l}\text { Diploid } \\
\text { Aneuploid }\end{array}$}} & 76 & 50 & 320 & 0.005 \\
\hline & & 86 & 108 & & \\
\hline \multirow{2}{*}{\multicolumn{2}{|c|}{$\begin{array}{l}\text { S-phase fraction } \leq 8 \% \\
\text { S-phase fraction }>8 \%\end{array}$}} & 57 & 43 & 220 & 0.50 \\
\hline & & 63 & 57 & & \\
\hline \multicolumn{2}{|l|}{$\mathrm{pS} 2$ negative* } & 85 & 75 & 332 & 0.72 \\
\hline \multicolumn{2}{|l|}{ pS2 positive* } & 88 & 84 & & \\
\hline
\end{tabular}

* by immunohistochemistry 
In univariate analysis it was demonstrated that high $\mathrm{MIB}-1(>7 \%)$ was associated significantly with shorter disease-free survival $(p<0.001$, see figure IV.1). Looking at subgroups, the same was found for node-negative patients $(\mathrm{p}<0.001$; see figure IV.2) while in node-positive patients no significant difference in diseasefree survival was demonstrated $(\mathrm{p}=0.24$, see figure IV.2). Furthermore, every cutoff point of MIB-1 from $2 \%$ to $25 \%$ showed a significant effect on disease-free survival in univariate analysis.

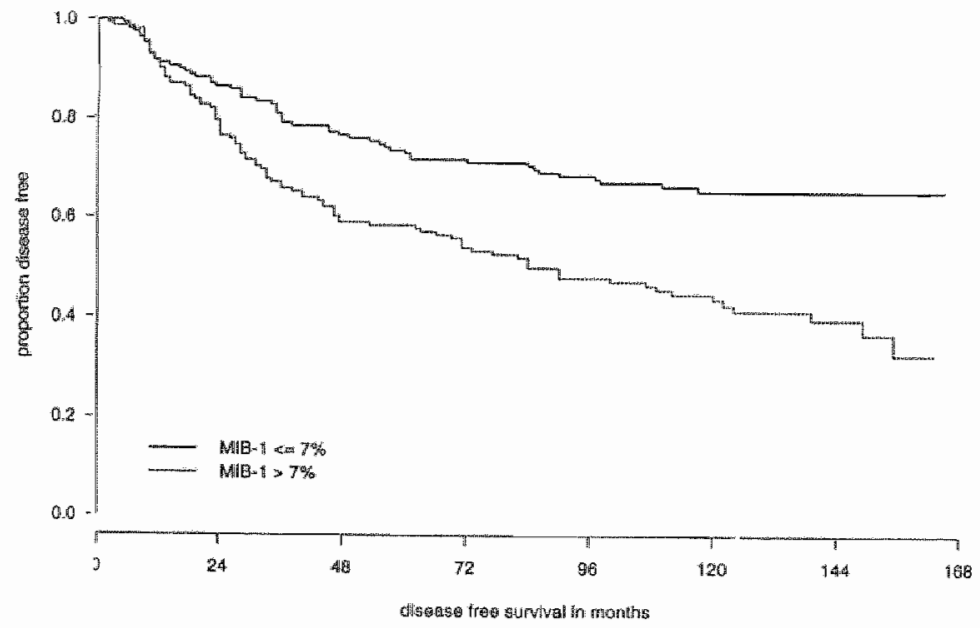

Figure IV.1 Disease-free survival curves for the whole group of 341 patients with low M.IB-1 labelling index $(\leq 7 \%)$ and thigh $M I B-1$ labelling index $(>7 \%)(p<0.001)$

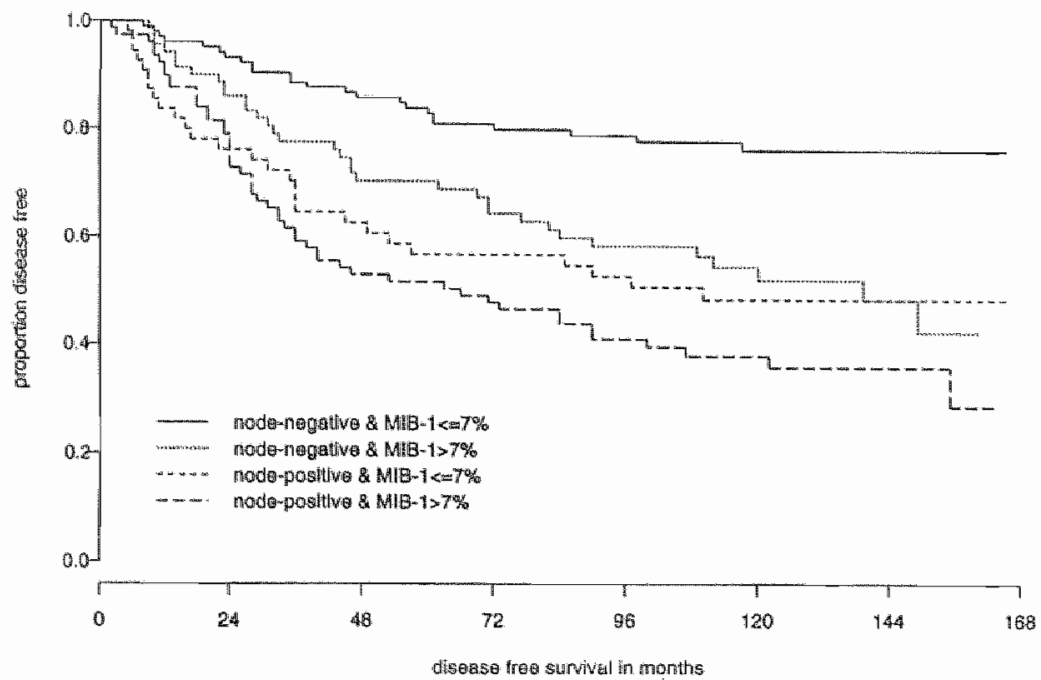

Pigure 1V.2 Disease-free surviwal curves for the group of 183 node-negative patients and the group of 138 node-positive patients with low MIB-1 labelling index $(\leq 7 \%)$ and high $M I B-1$ labelling index $(>7 \%)(p<0.001$ and $p=0.24)$ 
In multivariate analysis high MIB-1 $(>7 \%)$ was, besides the presence of axillary lymph node metastases the only independent prognostic factor for shorter diseasefree survival ( $p=0.004$; see table IV.2). The same was true when MIB-1 was analysed as a continuous variable $(\mathrm{p}=0,005$, data not shown). High MLB-1 $(>7 \%)$ showed a borderline significant association with overall survival in the whole group of patients ( $p=0.05$, see figure IV.3) but not in the node-negative and nodepositive subgroups.

In multivariate analysis for overall survival only the presence of axillary lymplu node metastases, T-stage more than $\mathrm{T}_{2}$ and age above 50 years, but not MrB-1 labelling index were independent prognostic factors (see table IV.3). Furthermore, MIB-1 was not associated with post-relapse survival.

Table IV.2 Multivariate analys is for disedse-free surviwal.

\begin{tabular}{lcc}
\hline & RHR* & P-value \\
\hline MIB-1 $(>7$ ws $\leq 7 \%)$ & 1.668 & 0.004 \\
T-stage (T2 vs T1) & 1.311 & 0.154 \\
T-stage (T3 ws T1) & 1.760 & 0.054 \\
Node status (positive vs negative) & 1.839 & 0.001 \\
Ploidy status (aneuploid vs diploid) & 1.412 & 0.122 \\
SPF $(>8 \mathrm{vs} \leq 8 \%)$ & 1.281 & 0.287 \\
ER $(>10 \mathrm{vs} \leq 10 \mathrm{fmol} / \mathrm{mg}$ protein) & 1.430 & 0.089 \\
PR $(>10 \mathrm{vs} \leq 10 \mathrm{fmol} / \mathrm{mg}$ protein) & 0.876 & 0.500 \\
Age $(>50 \mathrm{vs} \leq 50$ years) & 1.007 & 0.971 \\
\hline
\end{tabular}

* relative hazard rate

Table IV.3 Multivariate analysis for overall survival.

\begin{tabular}{|c|c|c|}
\hline & RHR* & $p$-value \\
\hline MIB-1 $(>7 \mathrm{vs} \leq 7 \%)$ & 1.091 & 0.598 \\
\hline $\mathrm{T}$-stage (T2 vs T1) & 1.262 & 0.205 \\
\hline T-stage (T3 vs T1) & 2.001 & 0.014 \\
\hline Node status (positive vs negative) & 1.595 & 0.008 \\
\hline Ploidy status (anceuploid vs diploid) & 0.933 & 0.74 .1 \\
\hline $\operatorname{SPF}(>8$ vs $\leq 8 \%)$ & $\llbracket .451$ & 0.089 \\
\hline $\mathbb{E R}(>10 v \mathrm{~s} \leq 10 \mathrm{fmol} / \mathrm{mg}$ protein $)$ & 1.194 & 0.370 \\
\hline $\mathrm{PR}(310 \mathrm{vs} \leq 10 \mathrm{fmol} / \mathrm{mg}$ protein $)$ & 0.802 & 0.241 \\
\hline Age $(>50$ vs $\leq 50$ years $)$ & 1.827 & 0.002 \\
\hline
\end{tabular}




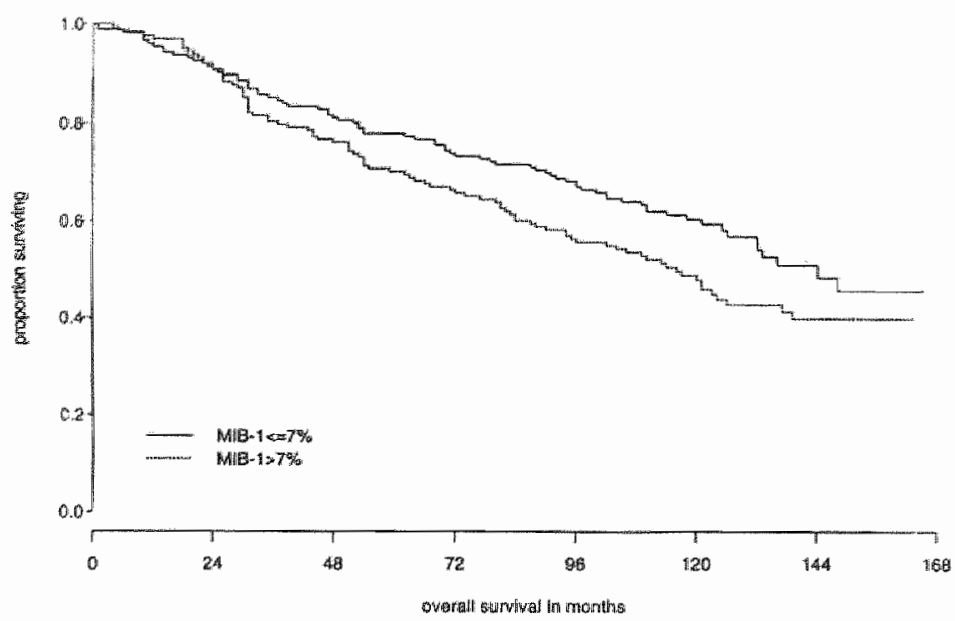

Figure IV.3 Owerall survival curwes for the whole group of 341 patients with low MIB-1 labelling index $(\leq 7 \%)$ and high $M I B-1$ labelling index $(>7 \%)(p=0.05$ )

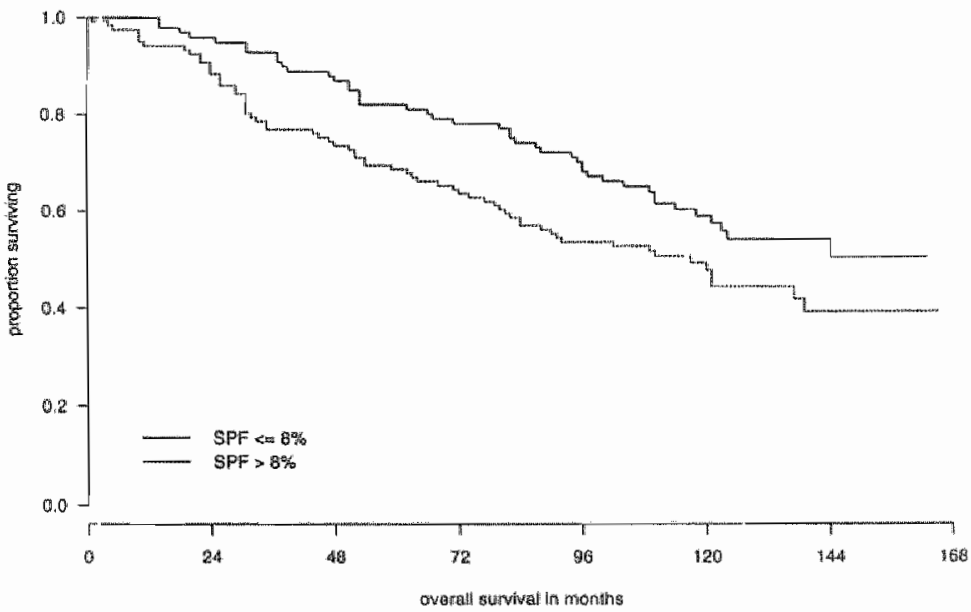

Figure IV.4 Overall survival curves for the group of 220 patients with low Sphase fraction $(58 \%)$ and high $S$-phase fraction $(>8 \%)(p=0.04)$

\section{S-phase fraction}

High S-phase fraction ( $>8 \%$ vs $\leq 8 \%$ ) was related with a significantly decreased overall survival in univariate analysis ( $p=0.04$; see figure IV.4). The effect of high $S$-phase fraction on overall survival was lost in multivariate analysis (see table IV.3). Concerning disease-free survival the effect of high S-phase fraction was borderline significant $(\mathrm{p}=0.06)$. With respect to post-relapse survival high $\mathrm{S}$-phase fraction was also an unlavourable prognostic factor $(p=0.03)$. In multivariate analysis $S$-phase fraction was a borderline prognostic factor looking at post-relapse survival $(p=0.08$; see table IV.4). 
Table IV.4 Multivariate analysio for post-relapse survival.

\begin{tabular}{lll}
\hline & RHR & p-value \\
\hline MIB-1 $(>7$ vs $\leq 7 \%)$ & 0.959 & 0.838 \\
T-stage (T2 vs T1) & 1.328 & 0.261 \\
T-stage (T3 vs Tl) & 2.417 & 0.019 \\
Node status (posicive vs negative) & 1.202 & 0.428 \\
Ploidy status (aneuploid vs diploid) & 0.950 & 0.841 \\
SPF $(>8$ vs $\leq 8 \%)$ & 1.585 & 0.083 \\
ER $(>10$ vs $\leq 10$ imol/mg protein) & 0.624 & 0.073 \\
PR $(>10$ vs $\leq 10$ fmol/mg protein) & 0.768 & 0.263 \\
Age $(>50$ vs $\leq 50$ years) & 1.300 & 0.242 \\
\hline
\end{tabular}

* relative hazard rate

\section{Combined prognostic value of MIB-1 and S-phase fraction}

Looking at a possible combined prognostic value of MIB-I and S-phase fraction only with respect to disease-free survival MIB-1 labelling index was a significant prognostic factor both for patients with tumours with low and high S-phase fraction ( $p<0.01$ in both cases). Concerning overall survival MIB-1 labelling index had an additional prognostic value only in case of a high $S$-phase fraction $(p=0.03)$. With respect to post-relapse survival no differences between subgroups could be demonstrated.

\section{Discussion}

In this study with long follow-up, MIB-1 expression was a significant prognostic factor for disease-free survival both in univariate and multivariate analysis, for both the whole group of patients and the 183 node-negative patients. MIB- 1 expression had borderline significant influence on overall survival. Not many studies have as yet investigated MIB-I as a prognostic factor. Three studies have demonstrated a significant influence of MIB-1 on overal $\|$ survival but have not mentioned diseasefree survival ${ }^{21.22 .33}$. The largest study on MIB-1 has shown a significant influence of MIB-1 on both disease-free and overall survival in multivariate analysis ${ }^{23}$ after a follow-up of 66 months. Remarkably, however, the by far largest study on Ki-67 in 674 node-negative breast cancer patients has found a significant influence on disease-free but not overall survival as in our study ${ }^{20}$. Several other studies have also shown a significant association of $\mathrm{Ki}-67$ and disease-free survival ${ }^{12.16 .18}$ and Ki-67 and overall survival ${ }^{16,18}$. Only two studies have not found such an association 
between Ki-67 and disease-free survival ${ }^{77.19}$. The results of the latter two studies could be explained by dividing the patients in three groups ${ }^{17}$ and by a relatively short follow-up period ${ }^{\text {ti }}$ respectively. However, multivariate analysis was not often performed. In our study we have found a significant influence of MIB-1 on diseasefree survival in node-negative, but not node-positive patients. Comparable results have been found in two other studies ${ }^{24.34}$. while one study has demonstrated an effect of MIB- 1 on disease-free survival for both groups of patients ${ }^{23}$. A difference in the prognostic value of MIB-1 for node-negative and node-positive patients could be explained by more susceptibility for adjuvant (chemo)therapy in node-positive patients with high MrB-1 labelling index, whereas node-negative patients were not treated by adjuvant systemic therapy.

The median percentage of MIB 1 positive cells in our patients $(7 \%)$ tended to be lower than the median value of $16-20 \%$ reported from several other studies ${ }^{11,21.22}$, but is comparable with the median value of two other reports ${ }^{19.35}$. For Ki-67 as measured in frozen sections also quite different median values varying from $2 \% 20$ to $12 \%{ }^{12}$ are reported. The reason for the considerable variability in $\mathrm{Ki}-67$ and MIB-I scores in the different studies is not directly clear. It seems likely that these differences can be explained at least partly because of different methodology (clifferent antibodies, different staining methods, different ways of counting). Therefore, it is certainly possible that comparable results of the MIB-I. (and Ki-67) labelling index will be found in different laboratories, when an uniform methodology is applied. In general, in comparative studies a good statistical correlation is found between Ki-67 and MJB-1 ${ }^{10.11}$.

In this study a low correlation coefficient of 0.15 between MIB-1 and SPF was found, which seems in line with the result of another study reporting on low correlation coefficients between Ki-67 and SPF (Spearman rank correlation of $0.15)$. Several other studies reported higher correlation coefficients between Ki-67 and $\mathrm{SPF}^{19}$ and between MIB- 1 and $\mathrm{SPF}^{35}$. In general, correlations are based on ancuploid tumours as in our study ${ }^{35.36}$. However, it has to be kept in mind that the Ki-67/MIB-I nuclear antigen is present in all parts of the cell cycle whereas $\mathrm{S}$ phase only relates to one specific stage in the cell cycle.

In the literature, data on the prognostic significance of SPF are conflicting and sometimes based on a low number of patients. When comparing MIB-1 and SPF in multivariate analysis one study has found SPF to be better than MIB-1 ${ }^{36}$ contradicury to our results. This could be explained by different methodology and patient selection. SPF is, however, not a method that is easily applied in routine practice.

Therefore, at this moment Ki-67 as measured on frozen sections or MlB-1 as measured on paraffin sections is probably the best method for assessing proliferation in a routine setting. This and several other studies have demonstrated the independent prognostic value of $\mathrm{Ki}-67$ and MIB- 1 in breast cancer patients. As 
with most other newer prognostic markers, however, at this moment it is not possible to use them for clinical decision-making. For that purpose it is at least necessary that a uniform methodology is developed. 


\section{References}

1. Epstein RJ. Routine or delayed axllary dissection for primary breast cancer? Eur I Cancer 1995; 31A: 1570-1573.

2. Fentman IS, Epstein $R$, Barr $L$. Is routine axillary nodal dissection necessary in the treatment of the breast cancer? Eur $\int$ Cancer $1996 ; 32 \mathrm{~A}: 1460-1463$.

3. Harris $J R$, Hellman $S$. Natural history of breast cancer. In: Harris JR, Lippmann ME, Morrow M, Hellman S, eds. Diseases of the breast, Philladelphia, LippincontRaven, 1996: 375-391.

4. Van Diest PI, Baak JPA, Matze-Cok P. Wisse-Brekelmans EC, van Galen CM, Kurver PH, Bellot SM, Fijheer J, van Gorp LH, Kwee WS, Los I, Peterse JL. Ruitenberg HM, Schapers RFM, Schipper MEI, Somsen JG, Willig AWPM, Ariens. AT. Reproducibility of mitosis counting in 2469 breast cancer specimens: results of the Multicenter Morphometric Mammary Carcinoma Project. Hum Pathol 1992; 23 : $603-607$.

5. Clayton F. Pathologic correlates of survival in 378 lymph node-negative infiltrating ductal breast carcinomas. Mitotic count is the best single predictor. Cancer 1991; 68: $1309-1317$.

6. Silvestrini R. Cell kinetics: prognostic and therapentic implications in human tumours. Cell Prolif 1994; 27: 579-596.

7. Silvestrini $R$, Daidone $M G$, Luisi $A$, Boracchi $P$, Mezzetti $M$, Di Fronzo $G$, Andreola S. Salvadori B, Veronesi U. Biological and clinicopathological factors as indicators of specitic relapse types in node-negatiwe breast cancer. J Clin Oncol 1995; 13: 697-704.

8. Hedley DW, Clark GM, Cornelisse CJ, Killander D, Kute T, Merkel D. Consensus review of the clinical utility of DNA cytometry in carcinoma of the breast. Breast Cancer Res Treat $1993 ; 28: 55-59$.

9. Gerdes I, Becker MHG, Key G. Immunohistological detection of tumour growth fraction (Ki-67 antigen) in formallin-fixed and routinely processed tissues. I Pathol (1.wetter) 1992; 168:85-86.

10. Remmele W, Muhlfait V, Keul HG. Estimation of the proliferative activity of human breast cancer tissue by means of the Ki-67 and MIB-1 antibodies comparalve studies on frozen and paraffin sections. Virchows Arch 1995; 426: $435-439$.

11. Veronese SM, Maisano C, Scibilia 1. Comparative prognostic value of Ki-67 and MiB - 1 proliferation indices in breast cancer. Anticancer Research 1996; 16: 2717 2722.

12. Bouzubar N, Walker KJ, Griffiths K, Ellis 10 , Elston CW, Robertson JFR, Blamey RW, Nicholson RI, Ki-67 immunostaining in primary breast cancer: pathological and clinical associations. $\mathrm{Br} J$ Cancer 1989; 59; 943-947.

13. Weikel W. Beck T, Mitze M. Knapstein PG. Immunohistochemical evaluation of growth fractions in human breast cancers using monoclonal antibody Ki-67. Breast Cancer Res Treat 1991: 18: 149-154 
14. Gaglia P, Bernardi A, Venesio T, Caldarola B, Lauro D, Cappa A.M. Calderini P. Liscia DS. Cell proliferation of breast cancer evaluated by anti-BrdU and anti-ki-67 antibodies: its prognostic value on short-term recurrences. Eur J Cancer 1993; 29A: $1509-1513$.

15. Railo $M$, Nordling $S$, von Boguslawsky $K$, Leivonen M, Kyllonen L., von Smitien $\mathrm{K}$. Prognostic value of $\mathrm{Ki}-67$ immunolabelling in primary operable breast cancer. $\mathrm{Br}$ J Cancer 1.993; 68: 579-583.

16. Veronese SM, Gambacorta M. Gotardi O, Scanzi F. Ferrari M, Lampertico P. Proliferation index as a prognostic marker in breast cancer. Cancer 1993; 71: 39263931.

17. Rudas M, Gnant MFX, Mittlbock M, Neumayer R, Kummer A, Jakesz R, Reiner $\mathrm{G}$, Reiner $\mathrm{A}$. Thymidine labelling index and $\mathrm{K}-67$ growth fraction in breast cancer: comparison and correlation with prognosis. Breast Cancer Res Treat 1994; 32: 165 175.

18. Gasparini $G$, Boracchi $P$, Verderio $P$, Bevilacqua $P$. Cell kinetics in human breast cancer: comparison between the prognostic value of the cytoluorimetric S-phase fraction and that of the antibodies to Ki-67 and PCNA antigens detected by immunocytochemistry. Int J Cancer 1994; 57: 822-829.

19. Keshgegian AA, Cnaan A. Proliferation markers in breast carcinoma: mitotic figure count, S-phase fraction, proliferating cell nuclear antigen, Ki-67 and MIB-1. An J Clin Pathol 1995; 104: 42-49.

20. Brown RW, Allred DC, Clark GM, Osborne CK, Hilsenbeck SG. Prognostic value of $\mathrm{Ki}-67$ compared to Suphase fracion in axillary node-negative breast cancer. Clin Cancer Res $1996 ; 2: 585-592$.

21. Jensen V, Ladekarl M, Holm-Nielsem P, Melsen F, Brandt Sorensen F. The prognostic value of oncogenic antigen 519 (OA-519) expression and proliferative activity detected by antibody MIB-I in node-negative breast cancer. I Pathol 1995; 176: 343-352.

22. Domagala W, Markiewski M. Harezga B, Dukowicz A. Osborn M. Prognostic significance of tumor cell proliferation rate as determined by the MIB-1 antibody in breast carcinoma: its relationship with vimentin and p53 protein. Clinical Cancer Res 1996; 2: 147-154

23. Seshadri R, Leong ASY, McCaul K, Firgaira FA, Setlur A, Horsfall DJ. Relationship between p53 gene abnormalities and other tumour characteristics in breast cancer prognosis. Int J Cancer (Pred Oncol) 1996; 69: 135-141.

24. Pietilainen $T$, Lipponen $P$, Aatromaa $S$, Eskelinen $M$, Kosma VM, Syrjänen $K$. The important prognostic value of Ki-67 expression as determined by image analysis in breast cancer. J Cancer Res Clin Oncol 1996; 122: 687-692.

25. Hupperets PSGJ, Wils J, Volovics L, Schouten L, Fickers M, Bron H, Schouten HC, Jager J, Smeets J, de Jong J, Blijham G. Adjuvant chemohomonal therapy with cyclophosphamide, doxorubicin and 5-fluorouracil (CAF) with or without medroxyprogesterone acelate for node-positive breast cancer patients. Ann Oncol 1993; 4: 295-301. 
26. Hupperets P, Wils J, Volovics L, Schouten L. Fickers M, Bron H, Schouten H,

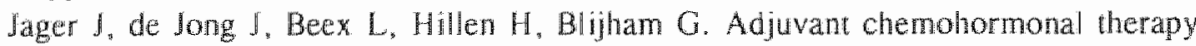
with cyclophosphamide, doxorubicin and S-fluorouracil (CAF) with or without medroxyprogesterone acetate for node-positve breast cancer patients: update at 7 years follow-up. Ann Oncol 1995; 6: 90-91.

27. Schutte B, Reynders MMJ, Bosman FTG, Blijham GH. Flow cytometric determination of DNA ploidy level in isolated nuclei from paraffin embedded tissue. Cylometry $1985 ; 6: 26-30$.

28. Hedley DW. Flow cytomery using paraffin-embedded tissue: five years on. Cytometry 1989; 10:229-241.

29. Vindelov L, Christensen U, Nissen NI. A detergent trypsin method for the preparation of nuclei for flow cytometric DNA analysis. Cytometry $1984 ; 5$ : $408-419$.

30. Hiddemann W, Schumann J, Andreef M, Barlogie B, Herman CJ, Leif RC, Mayall BH, Murphy RF, Sandberg AA. Convention of nomenclature for DNA cytometry. Cancer Genet Cytogenet 1984; 13: 181-183.

31. Shi SR, Key ME, Kalra KL. Antigen retrieval in formalin-fixed, paraffin-embedded tissues: an enhancement method for immunohistochemical staining based on microwave oven heating of tissue sections. J Histochem Cytochem 1991; 39: $741-748$.

32. Horiguchi J, Lino $Y$, Takei H. Expression of pS2 estrogen-inducible protein in primary breast cancer. Oncology 1996; 53: 12-15.

33. Pinder SE, Wencyk P, Sibbering DM, Bell JA, Elston CW, Nicholson R, Robertson JFR, Blamey RW, Ellis 10. Assessment of the new proliferation marker MIB- 1 in breast carcinoma using image analysis: associations with other prognostic factors and survival. Br J Cancer 1995; 71: 146-149.

34. Querzoli P, Abonico G, Ferretti S, Rinaldi R, Magri E, Indelli M, Nenci I. MlB-1 proliferative activity in invasive breasi cancer measured by image analysis. I Clin Pathol 1996; 49: 926-930.

35. Ellis PA. Makris A, Burton SA, Titley J, Ormerod MG, Salter I, Powles TJ, Smith IE, Dowsel M. Comparison of MIB-I proliferation index with S-phase fraction in human breast catrcinomas. Br J Cancer 1996; 73: 640-643.

36. Detmar P. Harbeck $N$, Thomssen $C$, Pache L, Ziffer P. Fizi K, Jänicke F, Nathath W. Schmit M. Graeff H. Hofler H. Prognostic impact of prolfferationassociated factors MIB-l (Ki-67) and S-phase in node-negative breast cancer. $\mathrm{Br}$ I Cancer 1997; 75: 1525-1533. 


\section{Chapter V}

\section{Relevance of the expression of bcl-2 in combination with p53 as a prognostic factor in breast cancer}

RLH Jansen, SR Joosten-Achjanie, A Volovics, JW Arends, PSGJ Hupperets, HFP Hillen, HC Schouten

Anticancer Research 1998 (in press) 


\section{Abstract}

\section{Background}

Both the proto-oncogene bel-2 and the tumour suppressor gene p53 are involved in the regulation of apoptosis.

\section{Patients and methods}

We have investigated the prognostic value of the immunohistochemical expression of p53 and bcl-2 separately and in combination in a group of 345 breast cancer patients from one hospital with a long median follow-up of more than 10 years.

\section{Results}

Bcl-2 expression was not a prognostic factor. p53 was an independent prognostic factor for overall survival $(p=0.005)$ and for post-relapse survival $(p=0.006)$. Looking at bcl$2 /$ p53 subgroups in the bel-2 positive subgroups there was a large difference in both disease-free and overall survival between 553 negative and $\mathrm{p} 53$ positive patients. In the bcl-2 negative subgroup the p53 sitatus was not a prognostic factor al all.

\section{Conclusion}

p53 is an independent prognostic factor for overall surwival and post-relapse survival. However, 53 status is only important in the bel-2 positive subgroups. 


\section{Introduction}

Several genes are involved in the regulation of programmed cell death (apoptosis). One of these genes is the bcl-2 proto-oncogene, encoding for a protein that may block apoptosis when prevailing over the bax gene product. $\mathrm{Bcl}-2$ overexpression was first identified in a high percentage of follicular B-cell lymphomas, associated with a $t(14 ; 18)$ translocation?

$\mathrm{Bcl}-2$ is, however, much more widely expressed than the lymphoid and hematopoietic system. It is present in glandular epithelium regulated by hormones, complex epithelia such as skin and the gastro-intestinal system and long living postmitotic cells such as neurons ${ }^{2}$. It has also been demonstrated in normal breast epithelium ${ }^{2.3}$ and in preinvasive breast lesions ${ }^{3.4}$.

Several studies have investigated the prognostic value of bcl-2 expression in primary breast cancer ${ }^{3.5-9}$. Generally high bcl-2 is associated with features of differentiation and good prognosis like low tumour grade ${ }^{3.57 .9}$, low proliferative activity $^{3.7 .9}$, oestrogen receptor (ER-)positivity ${ }^{5.9}$ and progesterone receptor (PR-)positivity ${ }^{5,7.9}$. Looking at disease-free survival and overall survival the expression of bcl-2 is associated with a better prognosis in univariate analysis in most studies ${ }^{3,6,8,9}$. This association is, however, lost in most ${ }^{3,6,9}$, but not all ${ }^{8}$ studies in multivariate analysis. The latter study suggests that the difference is only present in the node-positive subgroup ${ }^{8}$. Two of the studies in which prognostic significance was lost in multivariate analysis, were confined to node-negative patients, ${ }^{6.9}$ while the other study also found a favourable outcome for high bcl-2 only in nodepositive patients ${ }^{3}$. A possible explanation for this phenomenon is that bcl-2 is more a predictive factor for response to systemic therapy than a prognostic factor in itself. This has been demonstrated for the response to adjuvant treatment in nodepositive patients ${ }^{10}$ and the response to tamoxifen in ER-positive patients with metastatic breast cancer" ${ }^{\prime \prime}$.

The tumour suppressor gene p53 also plays a role in apoptosis, whereby it induces this process, in response to irreparable DNA damage. Cells deficient of normal ("wild-type") p53 are resistant to the induction of apoptosis ${ }^{12}$. Loss of p53 function allows the survival of cells with DNA-damage and is therefore associated with tumour progression. Mutation or inactivation of wild-type p53 could also block apoptosis, which is necessary for a response to hormonal or chemotherapy.

The prognostic role of $p 53$ in breast cancer has been elucidated in numerous studies mostly by immunohistochemistry. Almost invariably p53 was found to be an independent prognostic factor in studies with multivariate analysis ${ }^{\text {3.-1\% }}$. The prognostic effect of p53, however, is probably small ${ }^{19}$.

$\mathrm{Bcl}-2$ and $\mathrm{p} 53 \mathrm{can}$ also influence each other's effects. It has been demonstrated that bcl-2 is able to inhibit the apoptosis induced by $p 53^{20}$. However, also it has been shown that wild-type as well as mutant p53 proteins can down-regulate bcl-2 
expression $^{21}$.

We have investigated the prognostic value of bcl-2 and p53 separately and in combination in a group of 345 patients with primary breast cancer treated in a single hospital and with a long median follow-up of more than 10 years.

\section{Patients and Methods}

\section{Patients}

In the period May 1982-August 1987 the 345 patients were treated for primary breast cancer in the University Hospital Maastricht. Patients were selected according to the following criteria: 1. primary breast cancer without distant metastases, 2. no other primary tumour, 3. histological material available. All patients were staged at the time of diagnosis according to the TNM classification ${ }^{22}$. The median age was 57 years (range 25-87 years). Two hundred and twenty-three patients $(64.6 \%)$ had undergone a modified radical mastectomy, 98 patients (28.4\%) a lumpectomy with axillary lymph node dissection, whereas in 24 patients $(7.0 \%)$ only a biopsy was done either because of $T_{4}$ stage or high age. In 4 of these 24 patients an axillary lymph node dissection was done. One hundred eightyfive patients $(53.6 \%$ ) had no axillary lymph node metastases, 140 patients (40.6\%) had metastasis in one or more axillary lymph nodes, while in 20 patients $(5.8 \%)$ the axillary lymph node status was unknown. Axillary lymph node-positive patients younger than 70 years were treated with adjuvant chemotherapy consisting of 5-fluorouracil, adriamycin and cyclophosphamide. If they agreed to participate in a multicenter clinical trial, they were randomized for concomitant treatment with medroxyprogesteron acetate (MPA) or no MPA. The results of this clinical trial have been described in more detail elsewhere ${ }^{23.24}$. Axillary lymph node positive patients of 70 years and older were treated with tamoxifen. Axillary lymph nodenegative patients received no adjuvant systemic therapy. The median follow-up is 128 months (wange 61-170 months). During the follow-up 152 patients experienced a relapse: 88 had distan metastases, 46 a locoregional relapse and 18 both simultaneously at the time of first relapse.

\section{Methods}

\section{Immunohistochemistry (IHC)}

\section{Bcl-2 immunostaining}

Three $\mu \mathrm{m}$ sections were cut from routinely formalin-fixed and paraffin-embedded archival tumour blocks. Good tixation of the tumours on glass slides was obtained by overnight incubation of the tumour-slides in an $60^{\circ} \mathrm{C}$ oven on APS (3-aminopropyl trietoxysilane) (Sigma) coated glass-slides. 
Staining was performed using the mouse monoclonal anti-bcl-2 antibody (clone 124, DAKO, Denmark; 1:100, two hours incubation at room temperature).

To reach optimal staining results microwave antigen retrieval with citric buffer $(0.01 \mathrm{M}, \mathrm{pH}=6.0)$ was administered. A standard staining procedure was performed. In short: deparaffination in xylene and washes in $100 \%$ ethanol were followed with removing endogenous peroxidase in $0.3 \% \mathrm{H}_{2} \mathrm{O}_{2}$ containing methanol (30 minutes, room temperature). After washing away the excessive anount of methanol in demineralized water, the antigen unmasking procedure was performed. Non specific bindings were blocked with 5\% BSA-containing PBS (phosphate buffered saline, $\mathrm{pH}=7.4$ ). Then, the mouse anti $\mathrm{bcl}-2$ was applied to the tumour sections. Excessive amounts of antibodies were washed away in PBS. The avidinbiotin-peroxidase complex (Vectastain ABC Kit, Vector Laboratories, CA, USA) method was used to obtain amplification of the primary antigen-antibody bindings. These bindings were highlighted with DAB (di-amino-benzidin, Sigma). Finally, counterstaining with hematoxylin completed the staining.

\section{P53 immunostaining and other immunohistochemical determinations}

For other immunohistochemical staining procedures the anti-p53 mouse monoclonal antibody DO7 (DAKO A/S, Denmark, 1:200, two hours incubation at room temperature), the mouse monoclonal antibody MIB- 1 (Dianova, Germany, 1:100, one hour incubation at room temperature), rabbit polyclonal antibody NCl-pS2 (Novacastra Laboratories, UK, 1:400, one hour incubation at room temperature), and mouse monoclonal antibody against CD44v6 (R \& D Systems, UK, 1:1000, one hour incubation at room temperature) were used. Antigen unmasking by microwave antigen retrieval was done for p53, MIB- 1 and CD44v6-staining.

\section{IHC-score}

For bel-2 tumours were considered positive if more than $10 \%$ of cells showed positive staining, based on prior studies (only for bcl-2 tumours were scored semiquantitatively: negative; $0-10 \% ; 10-25 \% ; 25-50 \% ; 50-75 \%$ and $>75 \%$ of tumour cells staining). The same cut-off point was used for $\mathrm{p} 53^{25.26}$. For MIB-1 the median value of $7 \%$ was used. Tumours were considered pS2-positive in case of any positive staining, while for CD44v6 $5 \%$ was used as cut-off point.

\section{Steroid receptors}

The ER and PR assays were all performed on histologically proven breast cancer tissues using the dextran-coated charcoal method with multiple-point scatchard-plot analysis.

For all the assays the minimum cytosol protein concentration was $2 \mathrm{mg} / \mathrm{ml}$ cytosol. PR status was determined only in patients entered from August, $1983(n=252)$. 
Flow cylometric evaluation of ploidy status and S-phase fraction

Flow cytometric evaluation of ploidy status and S-phase fraction was done as described previously ${ }^{27}$.

\section{Statistical Analysiss}

Disease-frce survival was defined as the time from the day of diagnosis till the time of first relapse, death or last follow-up.

Overall survival was defined as the time from the day of diagnosis till the day of death or last follow-up.

Statistical analysis was done using the statistical package Stata (Stata Corp., 1997, Stata Statistical Software: Release 5.0, College Station, TX, USA). The association between the expression of bcl-2, p53 and other possible prognostic factors was analyzed by the chi-square test. Curves for disease-free survival and overall survival were estimated by the Kaplan-Meier method. Differences were analyzed using the logrank test.

Finally, prognostic variables were included in a Cox regression analysis.

\section{Results}

Bcl-2 expression and its relation to other clinicopathological factors

Positive staining in tumour cells for the bcl-2 protein was found in 205/337 $(60.8 \%)$ of the primary breast tumours. In all tumour sections lymphocytes were bcil-2 positive. Correlations between bcl-2 expression and other clinicopathological factors are shown in table V.1. No correlation was demonstrated with histology, and $S$-phase fraction, while a borderline correlation with lower tumour stage was found $(\mathrm{p}=0.054)$. Looking at histology, however, medullary carcinomas were mostly (15/19) bcl-2 negative. A significant association was demonstrated between bcl-2 expression and ER-positivity, PR-positivity, pS2-staining (all $p<0.001$ ), CD44v6-positivity $(p=0.003)$, diploidy $(p=0.008)$ and age $>70$ years $(p=0.02)$. A negative association of bcl 2 expression was found with MIB-1 and p53 staining (both $\mathrm{p}<0.001$ ). 
BCL-2 immunostaining and its relationship to other possible prognostic tactors.

\begin{tabular}{|c|c|c|c|c|}
\hline & Bcl-2 positive & Bd-2 negative & Number & pvatue \\
\hline $\begin{array}{l}E R \leq 10 \mathrm{fmol} / \mathrm{mg} \text { protein } \\
E R>10 \mathrm{mmol} / \mathrm{mg} \text { protein }\end{array}$ & $\begin{array}{r}25 \\
174\end{array}$ & $\begin{array}{l}70 \\
58\end{array}$ & 327 & $<0.001$ \\
\hline $\begin{array}{l}\mathrm{PR} \leq 10 \mathrm{fmol} / \mathrm{mg} \text { protein } \\
\mathrm{PR}>10 \mathrm{fmol} / \mathrm{mg} \text { protein }\end{array}$ & $\begin{array}{r}60 \\
101\end{array}$ & $\begin{array}{l}61 \\
39\end{array}$ & 261 & $<0.001$ \\
\hline $\begin{array}{l}\text { Age } \leq 50 \text { years } \\
\text { Age }>50 \text { years }\end{array}$ & $\begin{array}{r}65 \\
140\end{array}$ & $\begin{array}{l}44 \\
88\end{array}$ & 337 & 0.76 \\
\hline $\begin{array}{l}\text { Age } \leq 70 \text { years } \\
\text { Age }>70 \text { years }\end{array}$ & $\begin{array}{r}166 \\
39\end{array}$ & $\begin{array}{r}119 \\
13\end{array}$ & 337 & 0.02 \\
\hline $\begin{array}{l}\text { Ductal carcinoma } \\
\text { Other histological types }\end{array}$ & $\begin{array}{r}151 \\
54\end{array}$ & $\begin{array}{l}97 \\
35\end{array}$ & 337 & 0.97 \\
\hline $\begin{array}{l}\text { Node-negative } \\
\text { Node-positive }\end{array}$ & $\begin{array}{r}118 \\
78\end{array}$ & $\begin{array}{l}64 \\
58\end{array}$ & 318 & 0.18 \\
\hline Tumour-size: & $\begin{array}{r}98 \\
107\end{array}$ & $\begin{array}{l}49 \\
83\end{array}$ & 337 & 0.054 \\
\hline $\begin{array}{l}\text { Diploid } \\
\text { Aneuploid }\end{array}$ & $\begin{array}{r}86 \\
103\end{array}$ & $\begin{array}{l}39 \\
88\end{array}$ & 316 & 0.008 \\
\hline $\begin{array}{l}S \text {-phase fraction } \leq 8 \% \\
\text { S-phase fraction }>8 \%\end{array}$ & $\begin{array}{l}70 \\
68\end{array}$ & $\begin{array}{l}31 \\
49\end{array}$ & 218 & 0.09 \\
\hline $\begin{array}{l}\mathrm{MIB-1} \leq 7 \% \\
\mathrm{MIB-1}>7 \%\end{array}$ & $\begin{array}{r}123 \\
80\end{array}$ & $\begin{array}{l}52 \\
80\end{array}$ & 335 & $<0.001$ \\
\hline $\begin{array}{l}\text { p53 positive } \\
\text { p53 negative }\end{array}$ & $\begin{array}{r}62 \\
142\end{array}$ & $\begin{array}{l}68 \\
59\end{array}$ & 331 & $<0.001$ \\
\hline $\begin{array}{l}\mathrm{pS} 2 \text { negative } \\
\mathrm{pS} 2 \text { positive }\end{array}$ & $\begin{array}{r}82 \\
118\end{array}$ & $\begin{array}{l}76 \\
53\end{array}$ & 329 & 0.001 \\
\hline $\begin{array}{l}\text { CD44v6 }>5 \% \\
\text { CD } 44 v 6 \leq 5 \%\end{array}$ & $\begin{array}{r}143 \\
59\end{array}$ & $\begin{array}{l}71 \\
59\end{array}$ & 332 & 0.003 \\
\hline
\end{tabular}

\section{Bcl-2 expression and survival}

With respect to disease-free survival bcl-2 expression proved to have no prognostic value $(p=0.90$, see figure $V .1)$. Also for overall survival no difference could be demonstrated between bcl-2 positive and bcl-2 negative patients $(p=0.28$, see figure V.2). The Kaplan-Meier survival curves, however, suggested some timedependency for bcl-2 expression. After 3 years of follow-up there was a difference of about $10 \%$ between bcl-2 positive and bcl-2 negative patients both for diseasefree and overall survival. These differences virtually disappeared after the whole follow-up period (see figure V.I and figure V.2 respectively).

Looking at post-melapse survival there was a trend for a better prognosis for patients wit bol-2 positive tumours $(p=0.09)$. 


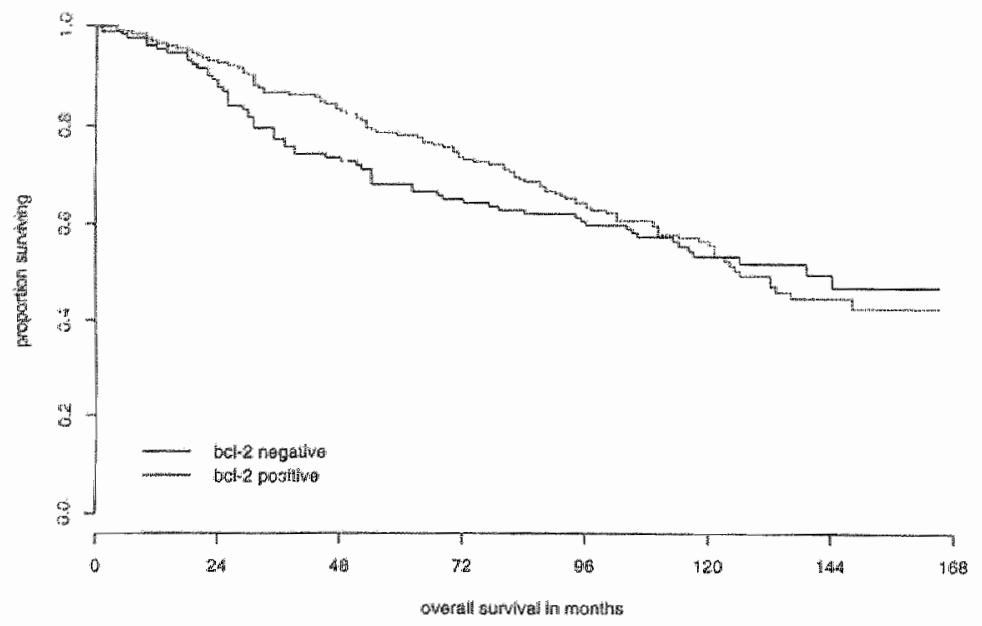

Figure V.I Overall servival in 337 pattents with bol-2 negative ( $\leq 10 \%$ staining) and BCL2 positive ( $>10 \%$ staining) tumours ( $p=0.90$ ).

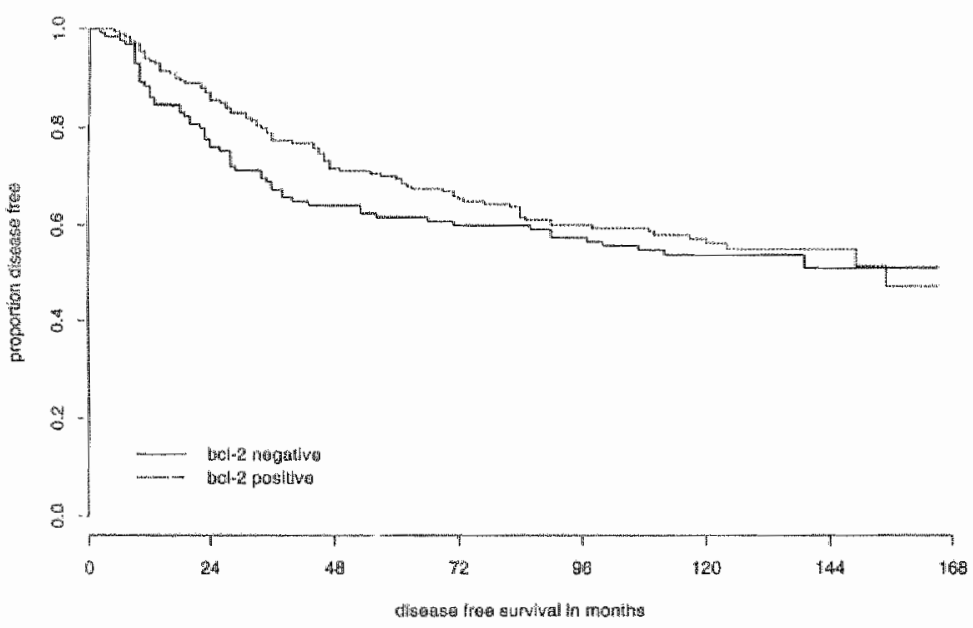

Fignare V.2 Distase-hee survical in 337 patients with bel-2 negative and bel-2 positiwe $(\leq 10 \%$ staing $)$ iumours $(p=0.28)$

p53 expression in relation to oher chimicopahological factors

Of the $33 \%$ breast tumours 131 (38.6\%) were p53 positive. P53 positivity was significantly more often seen in case of ER-negativity, bcl-2 negativity, pS2negativity, ductal histology and a high MTB-J percentage (see table V.2). P53 was not associated with nodal status, T-Stage, PR, S-phase fraction, ploidy, CD44V6 or agc (see table V.2). 

p53 immunostaing and its relationship to other possible prognostic factors.

\begin{tabular}{|c|c|c|c|c|}
\hline & p53 positive & p53 negative & Number & p-yalue \\
\hline $\begin{array}{l}\mathrm{ER} \leq 10 \mathrm{fmol} / \mathrm{mg} \text { protein } \\
\mathrm{ER}>10 \mathrm{~m} \text {. }\end{array}$ & $\begin{array}{l}55 \\
75\end{array}$ & $\begin{array}{r}41 \\
158\end{array}$ & 329 & $<0.008$ \\
\hline $\begin{array}{l}\mathrm{PR} \leq 10 \mathrm{fmol} / \mathrm{mg} \text { proteir } \\
\mathrm{PR}>10 \mathrm{fmol} / \mathrm{mg} \text { protein }\end{array}$ & $\begin{array}{l}52 \\
46\end{array}$ & $\begin{array}{l}71 \\
93\end{array}$ & 262 & 0.13 \\
\hline $\begin{array}{l}\text { Age } \leq 50 \text { years } \\
\text { Age }>50 \text { yedrs }\end{array}$ & $\begin{array}{l}49 \\
82\end{array}$ & $\begin{array}{r}61 \\
147\end{array}$ & 339 & 0.12 \\
\hline $\begin{array}{l}\text { Age } \leq 70 \text { years } \\
\text { Age }>70 \text { years }\end{array}$ & $\begin{array}{r}112 \\
19\end{array}$ & $\begin{array}{r}174 \\
34\end{array}$ & 339 & 0.65 \\
\hline $\begin{array}{l}\text { Ductal carcinoma } \\
\text { Other histological types }\end{array}$ & $\begin{array}{r}106 \\
25\end{array}$ & $\begin{array}{r}144 \\
64\end{array}$ & 330 & 0.02 \\
\hline $\begin{array}{l}\text { Node-negative } \\
\text { Node-positive }\end{array}$ & $\begin{array}{l}72 \\
52\end{array}$ & $\begin{array}{r}111 \\
84\end{array}$ & 319 & 0.84 \\
\hline $\begin{array}{l}\text { Tunowr-size: } \quad \begin{aligned} T & =1 \\
& T>1\end{aligned}\end{array}$ & $\begin{array}{l}51 \\
80\end{array}$ & $\begin{array}{r}98 \\
110\end{array}$ & 339 & 0.14 \\
\hline $\begin{array}{l}\text { Diploid } \\
\text { Aneuploid }\end{array}$ & $\begin{array}{l}43 \\
83\end{array}$ & $\begin{array}{r}83 \\
110\end{array}$ & 319 & 0.11 \\
\hline $\begin{array}{l}\text { Siphase fraction } \leq 8 \% \\
\text { S-phase fraction }>8 \%\end{array}$ & $\begin{array}{l}33 \\
46\end{array}$ & $\begin{array}{l}66 \\
74\end{array}$ & 219 & 0.44 \\
\hline $\begin{array}{l}\text { MIB-1 } \leq 7 \% \\
M L B-1>7 \%\end{array}$ & $\begin{array}{l}57 \\
74\end{array}$ & $\begin{array}{r}117 \\
87\end{array}$ & 335 & 0.01 \\
\hline $\begin{array}{l}\text { bel-2 positive } \\
\text { bcl-2 negative }\end{array}$ & $\begin{array}{l}62 \\
68\end{array}$ & $\begin{array}{r}142 \\
59\end{array}$ & 331 & $<0.001$ \\
\hline $\begin{array}{l}\mathrm{p} S 2 \text { negative } \\
\mathrm{p} S 2 \text { positive }\end{array}$ & $\begin{array}{l}71 \\
57\end{array}$ & $\begin{array}{r}85 \\
117\end{array}$ & 330 & 0.02 \\
\hline $\begin{array}{l}\mathrm{CD} 44 \times 6>5 \% \\
\mathrm{CD} 446 \leq 5 \%\end{array}$ & $\begin{array}{l}82 \\
48\end{array}$ & $\begin{array}{r}132 \\
69\end{array}$ & 331 & 0.63 \\
\hline
\end{tabular}

\section{p53 expression and survival}

In univariate analysis patients with p53 negative tumours had a significantly better overall survival $(p<0.01$, see figure V.3). Generally, overall survival worsened with a higher percentage of $p 53$ positive tumour cells.

In the nodenegative group of 183 patients p53 negative tumours were also associated with a better overall survival $(p=0.01)$, while in the node-positive subgroup $(n=136)$ the difference was borderline $(p=0.06)$.

With respect to disease-free survival there was a trend for a better prognosis with p53 negative tumours, but the difference was not statistically significant $(p=0.09)$. In the node-negative and node-positive subgroups there were no statistically significant differences $(p=0.13$ and $p=0.23$ respectively). 
We also investigated the role of p53 in post-relapse survival. Thereby it was shown that patients with p53 negative tumours had a significantly better survival after their first relapse. Remarkably this difference stanted to emerge only after about 2 years.

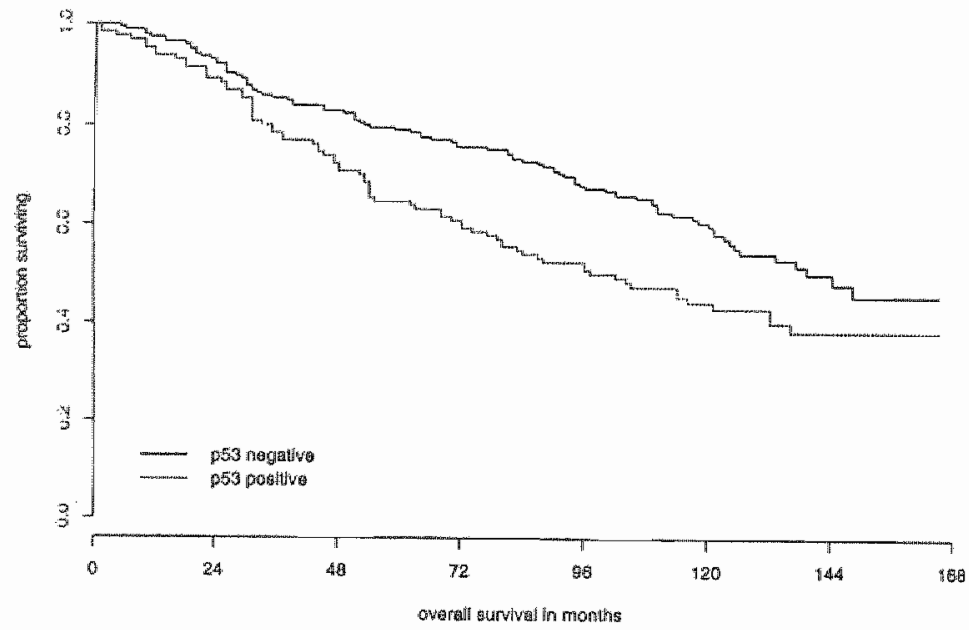

rigure V.3 Overall survival in 339 patients with p53 negative ( $\leq 10 \%$ staining) and p53 positive $(>10 \%$ stuining) tumours $(p<0.01)$.

Table V.3 Multivariate analysis for overall survival

\begin{tabular}{|c|c|c|c|}
\hline & RHR* & p-value & $95 \%$ confidence interval \\
\hline Age $(>50$ ws $\leq 50$ years $)$ & 1.881 & 0.002 & $1.272-2.782$ \\
\hline Nocle status (positive vs negative) & 1.680 & 0.004 & $1.183-2.386$ \\
\hline ER $(>10 \mathrm{vs} \leq 10 \mathrm{mmol} / \mathrm{mg}$ protein $)$ & 1.265 & 0.293 & $0.817-1.960$ \\
\hline $\mathrm{PR}(>10 \mathrm{vs} \leq 10 \mathrm{fmol} / \mathrm{mg}$ protein) & 0.829 & 0.328 & $0.569-1.208$ \\
\hline $0 \$ 2$ (posilive vas negative) & 0.877 & 0.434 & $0.630-1.219$ \\
\hline $\mathrm{SPF}(>8 \% \mathrm{v} \leq 8 \%)$ & 1.412 & 0.124 & $0.910-2.191$ \\
\hline Pluidy status (aneuplatial us diploid) & 0.956 & 0.833 & $0.632-1.447$ \\
\hline $053(>10 \% \times s \leq 10 \%)$ & $1.62 \|$ & 0.005 & $1.155-2.275$ \\
\hline hol-2 $(>10 \%$ vs $\leq 10 \%)$ & 1.136 & 0.521 & $0.770-1.676$ \\
\hline CD44v6 (positive ws negative) & 1.049 & 0.783 & $0.774-1.479$ \\
\hline$M 1 B-1(>7 \% v s \leq 7 \%)$ & 1.054 & 0.756 & $0.755-1.473$ \\
\hline$T_{\text {-stage }}\left(T_{3}, 4 s T_{i}\right)$ & 1.238 & 0.252 & $0.859-1.748$ \\
\hline$T$-stage $\left(T_{3}\right.$ and $T_{4}$ vs $\left.T_{1}\right)$ & 1.949 & 0.020 & $1.112-3.414$ \\
\hline
\end{tabular}

$* \mathrm{RHR}=$ relative hazand rate 


\section{Mulfivariate analysis}

In multivariate analysis p53 was an independent indicator for overall survival $(\mathrm{p}=0.003)$ besides axillary lymph node status, age and T3 tumour stage (see table V.3). Looking at disease-free survival, axillary lymph node status, tumour stage, MIB-I and ER-status were the only prognostic factors (data not shown).

In multivariate analysis p53 status was the most important independent factor for post-relapse survival $(\mathrm{p}=0.006)$ besides $\mathrm{pS} 2(\mathrm{p}=0.008)$ (see table V.4).

Table V.4

Multivariate andysis for post-relapse survival ${ }^{*}$

\begin{tabular}{lccc}
\hline & RHR* & p-value & 95\% confidence interval \\
\hline Age $(>50$ vs $\leq 50$ years) & 1.566 & 0.061 & $0.980-2.502$ \\
Node status (positive vs negative) & 1.213 & 0.421 & $0.758-1.941$ \\
ER $(>10$ vs $\leq 10$ fmol/mg protein) & 0.795 & 0.441 & $0.444-1.424$ \\
PR $(>10$ vs $\leq 10$ fimol/mg protein) & 0.681 & 0.120 & $0.420-1.104$ \\
pS2 (positive vs negative) & 0.563 & 0.008 & $0.367-0.864$ \\
SPF $(>8 \%$ vs $\leq 8 \%)$ & 1.465 & 0.160 & $0.860-2.496$ \\
Ploidy status (anneuploid vs diploid) & 0.986 & 0.956 & $0.596-1.632$ \\
p53 $(>10 \%$ vs $\leq 10 \%)$ & 1.768 & 0.006 & $1.174-2.664$ \\
Bcl-2 $(>10 \%$ vs $\leq 10 \%)$ & 1.147 & 0.575 & $0.711-1.848$ \\
CD44v6 (positive vs negative) & 0.828 & 0.385 & $0.540-1.269$ \\
MIB-1 $(>7 \%$ vs $\leq 7 \%)$ & 1.149 & 0.502 & $0.765-1.727$ \\
T-stage $\left(\mathrm{T}_{2}\right.$ vs $\left.\mathrm{T}_{1}\right)$ & 0.916 & 0.738 & $0.549-1.529$ \\
$\mathrm{~T}-\mathrm{stage}\left(\mathrm{T}_{3}\right.$ and $\mathrm{T}_{4}$ vs $\left.\mathrm{T}_{4}\right)$ & 1.885 & 0.093 & $0.899-3.951$ \\
\hline
\end{tabular}

* corrected for disedase-frece interval

* RHR = relative hazard rate

Subsets of bcl-2/p53 phenotypes and survival

Significant differences were found for disease-free survival between bcl-2/p53 subgroups $(p=0.01)$ (figure $V .4)$. The bcl-2 positive/p53 negative subgroup showed the best 5 -year survival $(77 \%)$ while in the bcl-2 positive/p53 positive subgroup the worst 5 -year survival was seen $(53 \%)$. Also with respect to overal survival significant differences between the bcl-2/p53 subgroups were seen $(\mathrm{p}<0.001)$ (figure V.5). In the bcl-2 positive subgroup the 5-year survival was $86 \%$ and $59 \%$ for the p53 negative and p53 positive patients respectively. Remarkably in both bcl-2 negative subgroups the p53 status did not essentially influence disease-free or overall survival.

In node-negative and node-positive subgroups comparable tendencies were found as 
in the whole group for disease-free and overall survival, whereby for disease-free survival the differences between the bcl-2/p53 subgroups only reached borderline significance $(p=0.07$ and $p=0.06$ for the node-negative and the node-positive subgroup respectively). We also investigated post-relapse survival in the same bcl$2 / p 53$ subgroups. Significant differences were demonstrated for the whole group of patients $(p=0.01)$ and the node-negative patients $(p<0.05)$, but not for the nodepositive patients $(p=0.28)$. For all patients with a relapse the longest median survival was seen in the bcl-2 positive/p53 negative patients: 33 months, versus 17 months for bcl-2 negative/p53 negative, 21 months for bcl-2 positive/p53 positive and 18 months for bcl-2 negative/p53 positive patients.

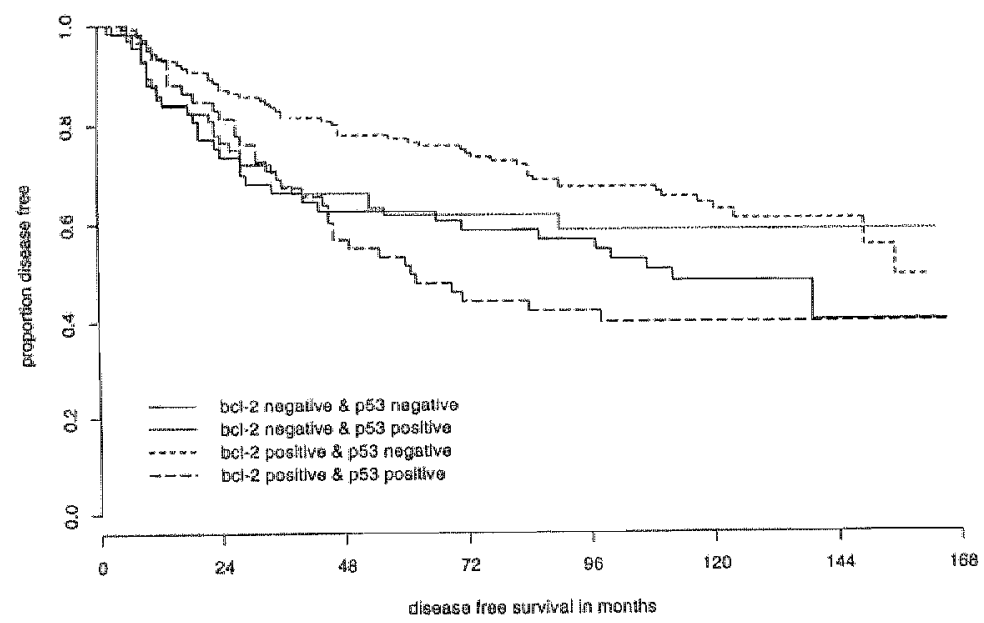

Figure V.4 Disease-free survival in bet-2/p53 subgroups $(p=0.01)$

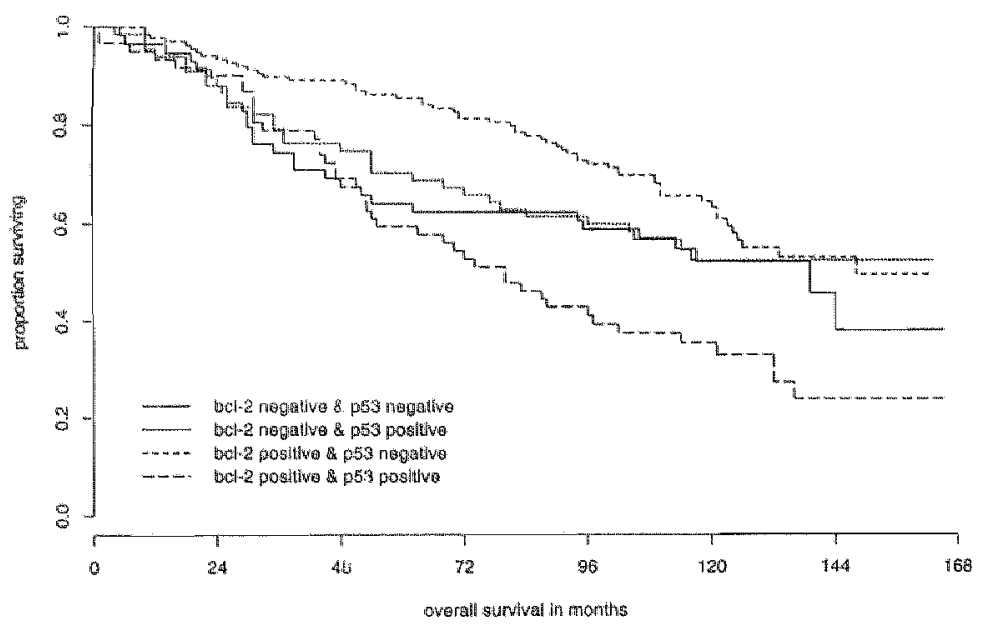

Figure V.5 Overall survival in bel-2/p53 subgroups $(p<0.001)$ 


\section{Discussion}

Numerous prognostic factors have been investigated in primary breast cancer. Especially factors involved in proliferation and growth control have been the subject of many studies. More recently apoptosis has been recognized as an important factor, i.e. tumour growth only occurs when the rate of proliferation exceeds that of death. P53 is a factor involved in growth control and apoptosis and is often referred to as "guardian of the genome".

In our study p53 expression was associated with a poor prognosis as has been reported by many ${ }^{13-18}$ but not all ${ }^{26.28}$ studies in the literature. In several studies p53 was an independent prognostic factor for both disease-free and overall servival ${ }^{14.16 .17}$, but sometimes only for disease-free survival ${ }^{18}$ or overall survival ${ }^{13}$. In our study a statistically significant effect of p53 in multivariate analysis was only found for overall survival. Differences between reported studies can be explained by different cut-off points for p53 positivity, different antibodies, variance in prognostic factors investigated in multivariate analysis and loss of p53 immunostaining intensity. We also have found a clear difference in post-relapse survival depending on p53 status. In multivariate analysis p53 was even the most important factor for post-relapse survival. An effect of p53 on survival after relapse has been reported before ${ }^{15}$, but is not investigated in most studies on p53 in breast cancer. It probably implies that "wild-type" p53 is necessary for a response to systemic therapy as has been found, although we were not able to investigate this in our study. Because of these findings and the suggestion that the prognostic value of p53 is probably small ${ }^{19}$ it seems reasonable to suggest that p53 is more useful as a predictive factor for response to systemic therapy than as a prognostic factor.

Our findings on the value of bcl-2 as a prognostic factor are in concordance with the literature. The fact that bol-2 seems to be a time-dependent factor confirms the results of the study of Joensuu et $\mathrm{al}^{3}$, while most other studies showing bcl-2 10 be a prognostic factor at least in univariate analysis have shorter follow-up $p^{6, k}$. Also the relationship of bcl-2 and other clinicopathological factors shows, in general, resemblance with other reported findings.

Most interesting are the findings in bel-2/p53 subgroups, whereby in the subgroup of bel-2 positive patients the p53 negative patients had a much better prognosis both for disease-free and overall survival than the p53 positive palienis. On the other hand in bcl-2 negative patients $\mathrm{p} 53$ status was not influencing prognosis anymore. Although a (negative) association between p53 and bel-2 has been reported before $e^{3.6}$, the combined prognosic value of both factors in subgroups has to our knowledge not been investigated so far. Recently, it has been reported that no clinically or statistically significant differences exist in response rate to tamoxifen in ER-positive melastatic breast cancer between the four possible phenotypes ${ }^{\mathrm{H}}$. However, as in our study the best post-relapse survival was found in 
p53 low/bcl-2 high patients".

It is rather surprising that bcl-2 expression is associated with good prognosis in breast cancer, because it would be expected to be associated with a nore aggressive behavior. It has been suggested that bcl-2 expression may produce slower growing tumours and reflects the maintenance of a more normal phenotype ${ }^{30}$. If this is the case, it would be less surprising that in bcl-2 positive breast tumours p 53 status is important for the prognosis of the patient but not necessarily related to apoptosis. On the other hand, if loss of bcl-2 expression is correlated with faster growth of breast cancer as suggested by the association with high MIB1 labelling index in our study, it is conceivable that p53 then does not play a role anymore. However, this is rather speculative and more studies on the effect of bol2 and $p 53$ on each other are needed.

In summary, we thave found that bcl-2 is not a prognostic factor. P53 is an independent prognostic factor for overall survival. This could partly be explained by the fact that it is also an independent prognostic factor for post-relapse survival, which suggests that p53 might be more a predictive than a prognostic factor. Furthermore, in bcl-2 positive tumours p53 status is very important with respect to prognosis, whereas in bcl-2 negative tumours p53 status is irrelevant. These latter findings need confirmation in other studies. 


\section{References}

1. Ngan BY, Chen-Lewy $Z$, Weiss LM, Warnke RA, Cleary ML. Expression in nonHodgkin's lymphomas of the bcl-2 protein associated with the $1(14 ; 18)$ chromosomal translocation. N Engl J Med 1988; 318: 1638-1644.

2. Hockenberry DM, Zutter $M$. Hickey W, Nalhm M, Korsmeyer SJ. Bcl-2 protein is topographically restricted in tissues characterized by apoptotic cell death. Proc Natl Acad Sci USA 1991; 88: 6961-6965.

3. Joenstu H, Pylkkänen L, Toikkanen S. Bcl-2 protein expression and long-term survival in breast cancer. Am J Path 1994; 145: 1191-1198.

4. Siziopikou KP, Prioleau JE, Harris JR, Schnitr S. Bcl-2 expression in the spectrum of preinvasive breast lesions. Cancer 1996; 77:499-506.

5. Nathan B, Gusterson B, Jadayel D, et al. Expression of bel-2 in primary breast cancer and its correlation with tumor phenotype. Am Oncol 1994; 5: 409-414.

6. Silvestrini $R$, Veneroni $S$, Daidone $M G$, et al. The bel-2 protein: a prognostic indicator strongly related to p53 protein in lymph node-negative breast cancer patients. J Natt Cancer Inst 1994; 86:499-504.

7. Binder $C$, Marx $D$, Overhoff $R$, Binder L, Schauer A, Hiddeman W. Bcl-2 protein expression in breast cancer in relation to established prognostic factors and other chinicopathological variables. Ann Oncol 1995; 6: 1005-1010.

8. Hellemans P, van Dam PA, Weyler J, van Oosterom AT, Buylaert P, van Marck E. Prognostic value of bcl-2 expression in invasive breast cancer. Br I Cancer 1995; 72: $354-360$.

9. van Slooten $H-J$, Clahsen $\mathbb{P C}$, van Dierendonck JH, at al. Expression of bel-2 in node-negative breast cancer is associated with various prognostic factors, but does not predict response to one course of perioperative chemotherapy. $\mathrm{Br} J$ Cancer 1996; 74: 78-85.

10. Gasparini $G$, Barbareschi $M$, Doglioni $C$, et al. Expression of bel-2 protein predicts efficacy of adjuvant treatments in operable node-posine breast cancer. Clin Cancer Res 1995; 1: 189-198.

11. Elledge RM, Green S. Howes $L$, et al. Bcl-2, p53 and response to tamoxifen in estrogen receptor-positive metastatic breast cancer: a Southwest Oncology Group Study. J Clin Oncol 1997; 15: 1916-1922.

12. Yonisch-Rouach E, Resnitzy D, Lotem J et al. Wild-type p53 induces apopotosis of myeloid leukaemic cells that is inhibited by interleukin-6. Naure 1991: 352: 345 347.

13. Thor AD, Moore II DH, Edgerton SM ei al. Accumulation of p53 tumor suppressor gene protem: an independent marker of prognosis in breast cancer. I Natl Cancer Inst 1992; $84: 845-855$.

14. Silvestrini R, Benini E, Daidone $M G$ et al. p53 as an independent prognostic marker in Iymph node-negative breast cancer patients. I Natl Cancer Inst 1993; 85: 965970. 
15. Barmes DM, Dublin EA, Fisher CI, Levison DA, Millis RR. Immunohistochemical detection of 053 protein in mammary carcinoma: an important new independent indicator of prognosis? Hum Pathol 1993; 24: 469-476.

16. Friedrichs $K$, Gluba $S$, Eidmann H, Jonat W. Overexpression of p53 and prognosis in breast cancer. Cancer 1993; 72.. 3641-3647.

17. Marks JR, Humphrey PA, Wu K et al. Owerexpression of p53 and HER-2/Neu proteins as prognostic markers in early stage breast cancer. Ann Surg 1994; 219 : $332-341$.

18. Gasparin $G$, Weidner $N$, Bevilacqua $P$ et al. Tumor microvessel density, p53 expression, tumor size and peritumoral lymphatic vessel invasion are relevant prognostic markers in node-negative breast carcinoma. J Clin Oncol 1994; 12: $454 \sim 466$.

19. Dowell SP, Hall PA. The p53 tumour suppressor gene and tumour prognosis: is there a relationship? J Path 1995; 177; $221-224$.

20. Chiou SK, Rao L, White E. Bcl-2 blocks p53 dependent apopotosis. Mol Cell Biol 1994: 14:2556-2563.

21. Haldar S, Negrini M, Monne M, Sabbioni S. Croce CM. Down-regulation of bel-2 by p53 in breast cancer cells. Cancer Res 1994; 54: 2095-2097.

22. Staging for carcinoma of the breast. In: Beahrs $O$, Henson $D$, Hutler $R$, Myers $M$. eds. Manual for staging of cancer. 3rd ed. Philadelphia, JB Lippincot 1988: $145-1.56$.

23. Hupperets PSGJ, Wils J, Volovics L, et al. Adjuvant chemohormonal therapy with cyclophosphamide, doxorubicin, and 5-fluorouracil (CAF) with or without medroxyrogesterone acetate for node-positive breast cancer patients. Ann Oncol 1993: 4: 295-301.

24. Hupperets P, Wils J, Volovics L, et al. Adjuvant hormonal therapy with cyclophosphamide, doxorubicin and 5-fluorouracil (CAF) with or without medroxyprogesierone acetate for node-positive breast cancer patients: update at 7 years follow-up. Ann Oncol 1995; 6: 90-91.

25. Rosen PP, lesser ML., Arroyo CD, Cranor M, Borgen P, Norton L. p53 in nodenegative breast carcinoma: an inmunohistochemical study of epidemiologic risk lactors, histologic features and prognosis. J Clin Oncol 1995; 13: 821-830.

26. Seshadri $\mathbb{R}$, Leong ASY, McCaul K, Firgaira FA, Sellur $V$, Horstall DJ. Relationshp between 053 gene abormalities and other tumour characteristics in brestst cancer prognosis. Int J Cancer (Pred Oncol) 1996; 69: 135-141.

27. Schute B, Reynders MMJ, Bosman FTG, Blijham GH. Flow cytometric determination of DNA ploidy level in nuclei isolated from paraffin-embedded tissue: live years on. Cytometry 1986; 6:26-30.

28. Pietilainen T. Lipponen P. Aaltoma $S$, Eskelinen $M$, Kosma V, Syrjanen $K$. Expression of p53 protein has no independent prognostic value in breast cancer. J. Path 1995; 177: 225-232.

29. Hawkins DS, Demers GW, Galloway DA. Inactivation of p53 enlnances sensitivity to multuple chemotherapeutic agents. Cancer Res 1996; 56: 892-898. 
30. Harris AL. What does bel-2 mean in solid tumors - friend or foe? Ann Oncol 1994; 5: $388-390$. 


\section{Chapter VI}

Microvessel density is correlated with age, but not with prognosis in breast cancer

RLH Jansen, SR Joosten-Achjanie, JW Arends, A Volovics, PSGJ Hupperets, HC Schouten, HFP Hillen

Submitted for publication 


\section{Summary}

Many studies in patients with breast cancer have shown an association between prognosis and microvessel density, mostly as determined by anti-FVIII-RAg or anti-CD31. From a theoretical point of view anti-CD34 should be a more suitable antibody.

Therefore, we have investigated the prognostic value of microvessel density as determined by immunostaining for CD34 in a large group of 324 patients with primary breast cancer and a median follow-up of more than 10 years.

Microwessel density by FVIII-RAg and CD34 showed a moderate correlation $\left(r_{\mathrm{p}}=0.54\right.$ for the highest counts and $r_{p}=0.58$ for the mean of three hotspots, both $p<0.001$ ). When microvessel density as determined by $\mathrm{CD} 34$ was analysed as a continuous variable an increasing risk of relapse with a rising number of microvessels was demonstrated. However, no single cut-off point could be found that lead to a significant difference in disease-free survival. Microvessel density as determined by FVIII-RAg showed no prognostic value for disease-free or overall survival. Remarkably, the mean microvessel density was lower in patients of 70 years and older compared to other age categories, which reached statistical significance only for FVIII-RAg $(p<0.001)$.

In conclusion: microvessel density as determined by current antibodies is not a useful prognostic factor in routine clinical practice. The association of lower microvessel density with higher age suggests a more favourable prognosis for this calegory of patients. 


\section{Introduction}

Although many prognostic factors have been investigated in primary breast cancer, so far the axillary lymph node status is still the most important prognostic factor. About $30 \%$ of the axillary node-negative patients and $70 \%$ of the node-positive patients will develop metastases. It would be of great clinical importance to have prognostic factors that indicate more precisely the subset of patients that will develop distant metastases. Angiogenesis could be such a prognostic factor since there is solid evidence that the extent of angiogenesis is correlated with metastasis in the pathophysiology of breast cancer. The biological background of angiogenesis in human breast cancer has recently been reviewed. One of the mosi widely applied methods to assess the angiogenic activity of a tumour is the measurement of the microvessel density. The original study of Weidner ${ }^{2}$ and many studies thereafter have investigated the prognostic role of microvessel density in primary breast cancer. Most of these studies demonstrate a correlation between a high microvessel density and poor outcome as has been reviewed ${ }^{1.3}$. The majority of the studies used anti-FVIII-RAg antibody. Although FVIII-RAg is highly specitic for the vasculature, it is absent on part of the capillary endothelium in tumour tissuet. Therefore, anti-FVIII-RAg antibody is probably not an optimal antibody to be used in the quantification of microvessel density, and it has been stated that anti-CD31 antibodies are superior on paraffin sections. However, a good alternative could be anti-CD34-antibody. It has been found that anti-CD31 and anti-CD34 demonstrated a similar degree of specific staining with less background staining for anti-CD34 Furthermore, CD34 is suggested to be a marker for the endothelial cells of newly formed vessels ${ }^{7.8}$, which makes it a very suitable antigen to use in the determination of microvessel density. So far only a few studies used anti-CD34-antibodies. fin. $^{91}$ of which only one small study with 77 patients compared different immunohistochemical methods for the assessment of angiogenesis including antiCD34 antibodies ${ }^{10}$.

Against this background we have investigated the prognosic value of microvessel density as determined by immunostaining for CD34 in a large group of 324 patients and compared this with the results of immunostaining for FVIIl-RAg. Furthermore, we have analysed possible associations with other prognostic factors previously investigated in these patients. The study was performed in patients from one hospital with a median follow-up of more than 10 years. 


\section{Patients and Methods}

\section{Patients}

The 324 patients were treated for primary breast cancer in the University Hospital Maastricht between May 1982 and August 1.987. Patients were included if they had primary breast cancer with no other primary tumour and without distant metastases, provided histologicall material was available. All patients were staged at the time of diagnosis according to the TNM classification ${ }^{12}$.

The median age was 56 years (range 28-87 years). Surgical treatment consisted of a modified radical mastectomy in 209 patients $(64.5 \%$ ), and a lumpectomy in 93 patients $(28.7 \%)$. In 22 patients $(6.8 \%)$ only a biopsy was done either because of $\mathrm{T}_{4}$ stage or high age, in 3 patients with an axillary lymph node dissection. In 136 patients $(42.0 \%)$ metastases were found in one or more axillary lymph nodes, while in 169 patients $(52.2 \%$ ) no axillary lymph node metastases were found and in 19 patients $(5.8 \%)$ the axillary lymph node status was unknown. Axillary lymph node-positive patients younger than 70 years were treated with adjuvant chemotherapy consisting of 5-fluorouracil, adriamycin and cyclophosphamide. If they agreed to participate in a multicenter clinical trial, they were randomized for concomitant treatment with medroxyprogesteron acetate (MPA) or no MPA. The results of this clinical trial have been described in more detail elsewhere ${ }^{13.14}$. Axillary lymph node-positive patients of 70 years and older were treated with adjuvant tamoxifen. Axillary lymph node-negative patients received no adjuvant systemic therapy. The median follow-up is 126 months (range 61-170 months). During the follow-up 145 patients experienced a relapse: 83 had distant metastases, 44 a locoregional relapse and 18 both a locoregional relapse and distant metastases at the time of first relapse.

\section{Methods}

\section{Immunohistochemistry}

\section{FVII/-related antigen and CD34}

From the routine formalin-fixed paraffin-embedded archival tumour blocks, slides of $3 \mu \mathrm{m}$ thickness were cut. Blood vessels were highlighted by staining endothelial cells for CD34 in one section (NCL-END mouse monoclonal antibody, Novocastra Laboratories, Newcastle, UK; 1:50) and for anti-FVIII-RAg vWF in a consecutive section (rabbit anti-luman VWF, Dako, Glostrup, Denmark; 1:2000). The immunohistochemical method used was the avidin-biotin-peroxidase-complex technique (Vectastain Elite $A B C$ kit, Vector, Burlingame, CA), a modification of the labelled-avidin-biotin method. Before antibody was added, sections were first. treated with $0.1 \%$ trypsin in $0.1 \% \mathrm{CaCl}_{2} \mathrm{H}_{2} \mathrm{O}$ (anti-CD34) and $0.1 \%$ pepsin in 0.1 $\mathrm{NHCl}$ (anti-vWF) for $10 \mathrm{~min}$. at room temperature. The antibodies were diluted in 
$0.5 \%$ PBS/BSA solution. Incubation with anti-CD34 was at $4^{\circ} \mathrm{C}$ overnight; antiVWF was incubated $45 \mathrm{~min}$. at room temperature.

Only slides of high staining quality (low background staining) were included.

\section{Microvessel density}

The highest vascularized areas (hot spots) were selected by scanning the tumour at low power. The hotspots were selected and counted using a $200 \mathrm{x}$ magnification $\left(0.60 \mathrm{~mm}^{2}\right)$. The criteria for microvessel recognition were the same as originally described by Weidner ${ }^{2}$. Briefly as microvessels were considered individual or clusters of cells, with or without a lumen and positively stained for factor VIII RAg or CD34. Three hotspots were counted on a $200 \mathrm{x}$ field. Both the mean of the three hotspots and the highest single value were recorded for each case. For analysis both vallues were used. Microvessel density was assessed without knowledge of patients outcome or characteristics.

Twenty samples were analysed independently by a second investigator to establish interobserver variability.

\section{Other immunohistochemical determinations}

For other immunohistochemical staining procedures the anti-p53 mouse monoclonal antibody DO7 (DAKO A/S, Denmark; 1:200, two hours incubation at room temperature), the mouse monoclonal anti-bcl-2 antibody (clone 124, DAKO, Denmark; 1:100, two hours incubation at room temperature), the mouse monoclonal antibody MIB-1 (Dianova, Germany; 1:100, one hour incubation at room temperature), rabbit polyclonal antibody NCI-pS2 (Novocastra Laboratories, UK; 1:400, one hour incubation at room temperature), and mouse monocional antibody against CD44v6 (R\&D Systems, UK; 1:1000, one hour incubation at room temperature) were used. Antigen unmasking by microwave antigen retrieval was done for 53, bcl-2, MIB-1 and CD44v6 staining.

\section{Immunohistochemistry score}

For bel-2 tumours were considered positive if more than $10 \%$ of cells showed positive staining, based on prior studies ${ }^{15}$ (only for bcl-2 tumours were scored semiquantitatively: negative; $0-10 \% ; 10-25 \% ; 25-50 \% ; 50-75 \%$ and $>75 \%$ of tumour cells staining). The same cut-off point was used for $053^{16}$. For MIB-1 the median value of $7 \%$ was used. Tumours were considered p52-positive in case of any positive staining, while for CD $44 \times 65 \%$ was used as cut-off point.

\section{Steroid receptors}

The ER and PR assays were all performed on histologically proven breast cancer tissues using the dextran-coated charcoal method with multiple-point scatchard-plot analysis. 
For all the assays the minimum cytosol protein concentration was $2 \mathrm{mg} / \mathrm{ml}$ cytosol. PR status was determined only in patients entered from August, $1983(n=252)$.

Flow olometric evaluation of ploidy status and S-phase fraction

Flow cytometric evaluation of ploidy status and $S$-phase fraction was done as described previously?

\section{Statistical Analysis}

Discase-free survival was defined as the time from the day of diagnosis till the time of first relapse, death or last follow-up.

Overall survival was defined as the time from the day of diagnosis till the day of death or last follow-up.

Statistical analysis was done using the statistical packages SAS (SAS Institute Inc., Cary, NC, USA) and S-plus (Statistical Sciences Europe, Oxford, UK). The association between microvessel density and other possible prognostic factors was analyzed by the chi-square test. Curves for disease-free survival and overall survival were estimated by the Kaplan-Meier method. Differences were analyzed using the logrank test.

\section{Results}

\section{Microvessel density}

It was not possible to determine the microvessel density in 5 patients for FVIIIRAg and 7 patients for CD34 because of insufficient material or low staining quality (high background staining). With respect to interobserver variability, the results of two investigators showed a very strong interobserver correlation (Pearson correlation $r=0.99, p<0.001$ ), if the same hotspots were counted. If hotspots were chosen independently, the correlation became weaker $(r=0.85, p<0.001)$. With respect to the intra-observer variability the Pearson correlation coefficient was 0.86 $(p<0.001)$. Looking at the highest microvessel count, the median value for FVIII$\mathrm{RAg}$ was $114 / \mathrm{mm}^{2}$ (range 15-353) and for CD34 131/ $\mathrm{mm}^{2}$ (range 13-370). With respect to the median value of the three hotspots the median value for FVIII-RAg was $104 / \mathrm{mm}^{2}$ (range 6-272) and $113 / \mathrm{mm}^{2}$ for CD34 (range 12-329). As could be expected the correlation between the highest count and the mean of three highest counts was very good (Pearson correlation coefficient 0.96 for FVIII-RAg and 0.98 for CD34, both $\mathrm{p}<0.001$ ). Correlation between microvessel density by FVIII-RAg and CD34 was moderate (Pearson correlation coefficient 0.54 for the highest counts and 0.58 for the mean of three hotspots, both $p<0.001$ ). 


\section{Association of microvessel density with age and other prognosic variables}

When tumours were categorized in three equal groups with low, intermediate and high microvessel density, both FVIII-RAg and CD34 showed a significant association with age ( $p=0.002$ and $p=0.03$ for highest count respectively, $p=0.001$ and $p=0.02$ for mean of three hotspots respectively). For both antigens the mean microvessel density was lower in patients of 70 years and older, compared to the patients of 50 years and younger and the patients of $51-69$ years which was only significant for FVIII-RAg (see table VI.1). Furthermore the microvessel density by FVIII-RAg showed a significant negative association with $S$ phase fraction ( $p=0.02$ both for highest count and mean of three hotspots), and the microvessel density by CD34 showed a significant association with axillary lymph node status, i.e. patients with high microvessel density had more often axillary lymph node metastases $(p<0.001$ both for highest count and mean of three hotspots).

Both FVIII-RAg and CD34 showed no association with steroid receptors, pS2, MIB-1 labelling index, p53, bcl-2, CD44v6, T-stage, histology, and ploidy status, When microvessel density was dichotomized at the median, comparable results were obtained.

Table VI.ll Mean values ( \pm SD) of microvessel density in different age cattegories.

\begin{tabular}{|c|c|c|c|c|}
\hline Prognostic variable & Age $\leq 50$ years & Age 51-69 years & Age $\geq 70$ years & p-value \\
\hline $\begin{array}{l}\text { MVD** } \\
\text { (FVIILRAgwighest value) }\end{array}$ & $147.9 \pm 65.5$ & $117.4 \pm 45.7$ & $107.4 \pm 34.6$ & $<0.0001$ \\
\hline $\begin{array}{l}\text { MVD* } \\
\text { (FVIII RAgmean } 3 \text { hot spots) }\end{array}$ & $124.5 \pm 51.6$ & $102.2 \pm 41.2$ & $94.5 \pm 31.0$ & $<0.000 \|$ \\
\hline $\begin{array}{l}\text { MVD* } \\
\text { (CD34-highes value) }\end{array}$ & $148.5 \pm 59.3$ & $139.2 \pm 64.1$ & $129.1 \pm 56.0$ & 0.16 \\
\hline $\begin{array}{l}\text { MVD } \\
\text { (CD34 matan } 3 \text { ntot spotsis) }\end{array}$ & $127.7 \pm 51.6$ & $118.3 \pm 54.1$ & $110.1 \pm 49,0$ & 0.12 \\
\hline
\end{tabular}

* MVD microvessel density

\section{Microvessel density and survival}

Microvessel density as determined by FVIII-RAg showed no prognostic value for disease-free survival or overall survival, neither for the highest count nor for the mean of the three hot spots. This was true when patients were divided in three categories with low, intermediate or high microvessel density or dichotomized att. the median value.

When the microvessel density as determined by CD34 was analysed as a 
continuous variable, there was an increasing risk of relapse with a rising number of microvessels (figure V1.1). However, no cut-off point could be found that lead to a significant difference in disease-free survival. When patients were again divided in three equal groups with low, intermediate or high microvessel density, also no significant difference in disease-free survival was found (figure VI.2) $(\mathrm{p}=0.15)$. Only when the group with the highest microvessel density was compared with the two other groups, there was a borderline significant difference in disease-free survival $(p=0.06)$. Thereby the differences in disease-free survival were fully accounted for by a different risk for distant metastases, whereas CD34 had no association with the risk for a locoregional relapse. Furthermore, also for overall survival no differences between the three groups could be demonstrated $(p=0.33)$. In multivariate analysis for disease-free survival only axillary lymph node status, MIB-I labelling index and T3 or T4 stage were independent prognostic factors (see table VI.2).

Table VI.2 Mulivariate analysis for disease-free survival.

\begin{tabular}{|c|c|c|c|}
\hline & $\mathbb{R H R}^{*}$ & prevalue & $95 \%$ Confidence interval \\
\hline Age $(>50$ vs $\leq 50$ years $)$ & 1.086 & 0,68 & $0.734-1.607$ \\
\hline Node status (positive ws negative) & 1.791 & 0.002 & $1.23 \llbracket-2.606$ \\
\hline ER $(>10 \mathrm{ws} \leq 10 \mathrm{fmol} / \mathrm{mg}$ protein $)$ & 1.516 & 0.08 & $0.946-2.430$ \\
\hline$P R(>10 \mathrm{ws} \geq 10 \mathrm{fmol} / \mathrm{mg}$ protein $)$ & 0.912 & 0.65 & $0.616-1.350$ \\
\hline pS2 (positive vs neystive) & 1.229 & 0.25 & $0.862-1.751$ \\
\hline $\mathrm{SPF}(>8 \mathrm{vs} \leq 8 \%)$ & 1.228 & 0.40 & $0.762-1.979$ \\
\hline Plondy status (aneuploid vs diploid) & 1.4110 & 0.13 & $0.901-2.207$ \\
\hline $053(>10$ ws $\geq 10 \%)$ & 1.370 & 0.09 & $0.951-1.973$ \\
\hline hol-2 (nositive vs negative) & 0.904 & 0.64 & $0.597-11.371$ \\
\hline CD44v6 (positive vs negative) & .029 & 0.88 & $0.717-1.477$ \\
\hline $\mathrm{MIB} 1(>7 \mathrm{~W} \leq 7 \%)$ & 1.567 & 0.01 & $1.094-2.246$ \\
\hline MVD' (intermediate vs low) & 0.987 & 0.96 & $0.619-1.575$ \\
\hline$M V D^{*}$ (high vis lowe) & 1.417 & 0.14 & $0.893-2.248$ \\
\hline$T$-stage $(T$, vs $T)$ & 1.341 & 0.13 & $0.920-11.956$ \\
\hline$T$-stage $\left(T, T_{3} T_{1}\right)$ & 1.899 & 0.04 & $1.040-3.466$ \\
\hline
\end{tabular}

"RHR $=$ relative hazard rate; "MVD = microvessel density as determined by highest count for CD.34. 


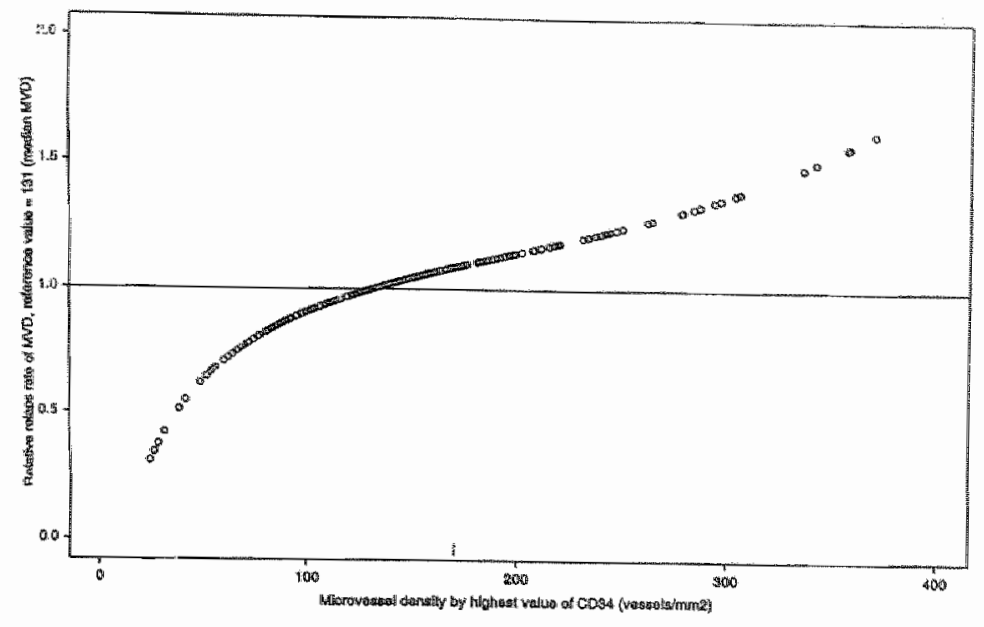

Figure VI.I Relative risk of relapse as determined by the number of microvessels/mm (highest value of $\mathrm{CD} 34$ ).

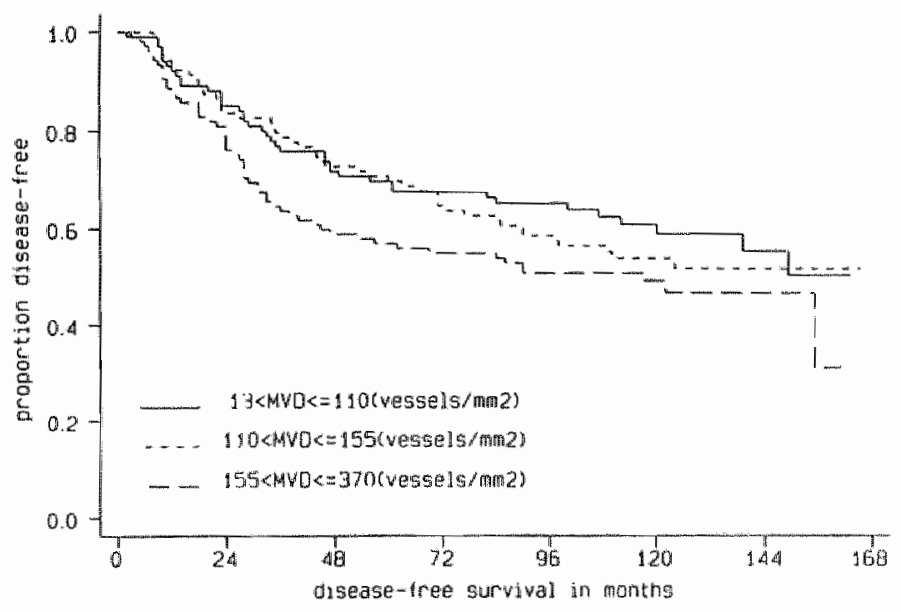

Figure VI.2 Disease-tree surwival for patients with fow inermediate and high microvessel density as determined by the highest coun for CD $4.4(p=0.15)$

\section{Discussion}

The last years many studies have been done to investigate the prognostic value of microvessel density in primary breast cancer. As stated in several reviews, most studies have demonstrated a significant association between microvessel density and 
discase-free and overall survival in univariate analysis and often also in multivariate analysis. In our study, we have demonstrated an increasing risk of relapse with an increasing microvessel density as determined by CD34. However, we were not able to find a cut-off point leading to a statistically significant difference. Negative studies have in the past been criticized mainly because of methodological problems ${ }^{13}$, and have lead to some vivid discussions in the literature ${ }^{19-23}$.

Therefore, recently an international consensus on the methodology and criteria of evaluation with respect to the quantification of angiogenesis in solid tumours has been proposed ${ }^{5}$. Our methodology was quite similar to the proposed standard method, but we used the original method of Weidner ${ }^{2}$ instead of the Chalkley point graticule method to count microvessels. Furthermore, anti-CD34 was used instead of anti-CD31.

Looking at the studies on intratumoural microvessel density and prognosis in operable breast carcinoma as summarized in a recent review', it seems that another factor could be of importance. None of the 4 studies with a median follow-up longer than 9 years has demonstrated an association of microvessel density with prognosis either in univariate or in multivariate analysis ${ }^{4,19,24,25}$. This suggests that microvessel density might be a time-dependent prognostic factor. Although the disease-free survival curves in our own study could suggest such a time-dependent effect, statistically this could not be confirmed. Because in none of the 4 articles mentioned above with a follow-up of more than 9 years survival curves are provided, this cannot be judged from the data presented. These results are, however, contradictory to a more recent published study in which after a follow-up of more than 15 years the microvessel count by the use of monoclonal anti-CD34 was an independent prognostic factor ${ }^{26}$. The methodology in that study was more different from the proposed standard because of the use of a small microscopic

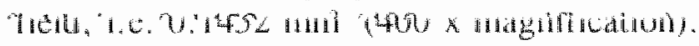

Remarkably, our results demonstrate an association between age older than 69 years and lower microvessel density both for FVIII-RAg and CD34. This is in concordance with the findings of two other studies ${ }^{27.26}$ and suggests a better prognosis for older patients with primary breast cancer.

In out study as in most other studies we have not found an association of microvessel density with other prognostic factors like steroid receptors, p53, ploidy status, proliferative activity and histology. With respect to $\mathrm{T}$ - and $\mathrm{N}$-stage data in the literature are conflicting. While the majority of studies has not demonstrated an association with T'-stage, about hall of the studies does show an association with $\mathrm{N}$-stage. Our findings demonstrate an association between CD34 and axillary lymph node status.

When comparing the different antibodies (anti-FVIII-RAg and anti-CD34), it was easier to count microvessels in slices stained with CD34, especially because of low background staining. Furthermore from a theoretical point of view anti-CD34 
should be preferred above anti-FVIII-RAg because of better specificity ${ }^{7.8}$. In conclusion, angiogenesis is without doubt important in tumour development and spread. However, determination of angiogenetic activity by microvessel count has given rise to conflicting results mainly because of methodological problems. To our opinion, the proposed standard method can only partly solve these problems because of several subjective aspects. Therefore, at this moment it is unlikely that microvessel density as determined by the current antibodies is a prognostic factor that is useful in routine clinical practice for patients with primary breast cancer. Furthermore, assuming that microvessel density is a prognostic factor despite methodological problems, the correlation of lower microvessel density with age above 69 years suggests a better prognosis in these older patients. 


\section{References}

1. Gasparin G. Clmical significance of the determination of angiogenesis in human breast cancer: update of the biological background and overview of the Vicenza studies. Eur ICancer 1996; 32A: 2485-2493.

2. Weidner $\mathbb{N}$, Semple JP, Welch WR, Folkman I. Tumor angiogenesis and metastasis - correlation in invasive breast carcinoma. $N$ Engl J Med 1991; 324:1-8.

3. Gasparin G, Harmis AL. Clinical importance of the determination of tumor angiogenesis in breast carcinoma: much more than a new prognostic tool. $J$ Clin Oncol 1995; 13: 765-782.

4. Vermeulen PB, Verhoeven D, Fierens $H$ et al. Microvessel quantification in primary colorectal carcinoma: an immunohistochemical study. Br J Cancer 1995. $71: 340-343$.

5. Vermenlen PB, Gasparini G, Fox SB, Toi M, Martin L, McCulloch P. Pezzella F* Viale $G$, Weidner $N$, Harris $A L$, Dirix $L Y$. Quantification of angiogenesis in human solid dumors: an international consensus on the methodology and criteria of Evaluation. Eur J Cancer 1996; 32A: 2474-2484.

6. Simpson $\mathbb{N F}$, Ahn C. Battifora H. Esteban JM. Endothelial area as a prognostic indicator for invasive breast carcinoma. Cancer 1996; 77: 2077-2085.

7. Schlingemann RO. Rietweld FJR, de Waal RMW Bradley NJ, Skene AI, Davies AJS, Greaves MF, Denekamp I. Ruiter DI. Leukocyte antigen CD34 is expressed by a subset of cultured endothelial cells and on endothelial abluminal microprocesses in the tumor stroma. Lab Invest $1990 ; 62: 690-696$.

8. Van de Rijn M, Rouse RV. CD34. A review. Appl Immunohistochem 1994: 2: 71 80 .

9. Goulding H, Nik Abdul Rashid NF", Robertson JJ", Bell JA, Elston CW, Blamey RW, Ellis 10. Assessment of angiogenesis in breast carcinoma: an important factor in prognosis? Hum Pathol 1995; 26: 1196-1200.

10. Sifonen SM. Harpasalo HK, Rantala JS, Helin HJ, Isola JJ. Comparison of different immunohistochemical methods in the assessment of angiogenesis: lack of prognostic value in a group of 77 selected node-negative breast carcinomas. Modern Pathol 1995; 8: 745-752.

11. Heimam R, Ferguson D, Powers C, Recant WM, Weichselbaum RR. Hellman S. Angiogenesis as a predictor of long-term survival for patients with node-negative breast cancer. I Naul Cancer Inst 1996; 88: 1764-1769.

12. Staging for carcinoma of the breast. In: Beahrs O. Henson D. Hutler R, Myers M, eds. Manual for shaging of cancer. 3rd ed. Philadelphia, JB Lippincott 1988: 145 156.

13. Hupperets PSGJ. Wils J, Volovics L, et al. Adjuvant chemolnormonal therapy with cyclophosphamide, doxorubicin, and 5-fluorouracil (CAF) with or without medroxyrogesterone acetate for node-positive breast cancer patients. Ann Oncol $1993: 4: 295-301$ 
14. Hupperets P. Wils J, Volovics L, et al. Adjuvant chemohormonal therapy with cyclophosphamide, doxorubicin and 5-fluorouraci (CAF) whith or without medroxyprogesterone acetate for node-posinive breast cancer patients: update at 7 years follow-up. Ann Oncol 1995; 6:90-91.

15. Hellemans P, van Dam PA, Weyler J, van Oosterom AT, Buytaert P. wan Marck E. prognostic value of bcl-2 expression in invasive breast cancer. Br J Cancer 1995 : 72: $354-360$.

16. Rosen PP, Lesser ML, Arroya CD, Cranon M, Borgen P, Norton L. p53 i nodenegative breast carcinoma: an immunohistochemical study of epidemiologic risk factors, histologic feaures and prognosis. J Clin Oncol 1995; 13:821-830.

17. Hupperets PS, Schute B, wan Assche C et al. Ploidy and S-phase fractions (SPF) of primary breast cancer and their nodat metastases. Breast Cancer Res Treat 1994; 32: $197-202$.

18. Gasparini $G$, Harris AL. Clinical importance of the determination of tumor angiogenesis in breast carcinoma: much more than a new prognostic tool. I Clin Oncol 1995; 13: 765-782.

19. Axelsson K, Ljung B-ME, Moore DH II, Thor AD. Chew KL, Edgerton SM, Smith HS. Mayall BH. Tumor anglogenesis as a prognostic assay for invasive ductal breast carcinoma. I Natl Cancer Inst 1995; 87: 997-1008.

20. Vermeulen PB, Libura I, Libura M. Hellemans PWJ, van Marck $\mathbb{E}$, van Oosterom AT, Dirix $\mathbb{L}$ Y. Tumor angiogenesis as a prognostic assay for invasive ductal breast carcinoma. I Narl Cancer Inst 1995; 87: 1797-1798.

21. Fox SB, Catter KC, Alman DG, Leek RD, Harris AL. Tumor anglogenesis as a prognostic assay for invasive ductal breast carcinoma. J Natl Cancer lnst 1995; 87: 1798-1799.

22. Gasparini $\mathrm{G}$. Tumor angiogenesis as a prognostic assay for invasive ductal breast Carcinoma. I Natl Cancer Inst 1995; 87: 1799-1801.

23. Axellsson K, Ljung B-ME, Chew KL, Mayall BH, Moore DH II, Smith HS, Thor $A D$, Edgerton SM. Tumor angiogenesis as a prognostic assay for invasive ductal breast carcinoma. J Natl Cancer Inst 1995: 87: 1801-1802.

24. Hall NR, Fish DE, Hunt $N$, Goldin RD, Guillou PJ, Monson JRT. Is the relationship between angiogenesis and metastasis in breast cancer real? Surg Oncol 1992: 1: $223-229$.

25. Van Hoef MEHM, Knox WF. Dhesi SS, Howell A, Schor AM. Assessment of umour vascularity as a prognostic factor in lymph node negative invasive breast cancer. Eur J Cancer 1993; 29A: 1141-1145.

26. Heimann $R$, Ferguson D, Powers C. Recant WM, Weichselbaum RR, Hellman S. Angiogenesis as a predictor of long-term survival for patients with node-negative breast cancer, J Natl Cancer Inst 1996; 88: 1764-1769.

27. Millaras D, Kamas A, Kalekou H. Angiogenesis in invasive breast carcinoma: is it associated with parameters of prognostic significance? Histopathology 1995; 26 : $165-169$. 
28. Marinho A, Soares R, Ferro J, Lacerda M, Schmitt FC. Angiogenesis in breast cancer is related to age but not to other prognostic parameters. Pathol Res Pract $1997 ; 193: 267-273$. 


\section{Chapter VII}

Summary and general discussion 


\section{Summary and general discussion}

Breast cancer is the most frequent malignancy in women in the Netherlands, affecting more than 10,000 new patients each year. Despite a rising incidence the mortality over the last few years has remaned stable. This improvement in prognosis is most likely explained by two factors: firsly tumours are diagnosed at an earlier and, therefore, more curable stage, and secondly systemic adjuvant treatment with homonal therapy, chemotherapy or both has resulted in better disease-free and overall survival. Unfortunately, despite these advances, not every patient benefits from adjuvant therapy. Historically, only patients with axillary lymph-node metastases have been treated with adjuvant therapy, although there is now an increasing tendency to treat unfavourable subsets of patients without axillary lymph node metastases. There remains, however, uncertainy regarding which are the most important prognostic factors. There is an need to define factors which can predict outcome for individual patients such that those who have a high chance of cure with loco-regional therapy alone are spared the side effects of systemic therapy whilst those patients with a high risk of recurrence can receive tailored systemic therapy. Over the last two decades many prognostic factors have been investigated in primary breast cancer. We have investigated the value of several more recently developed prognostic factors by immunohistochemistry in a group of 349 patients with primary breast cancer from one hospital, uniformly treated and with a median follow-up of more than 10 years.

In Chapter 1 a review is given of the literature on prognostic factors. Hundreds of studies have investigated dozens of prognostic factors, mostly in retrospective studies often with relatively few patients and generally short follow-up. It can be concluded that only more traditional prognostic factors such as axillary lymph-node status, tumour size, prolilerative activity and probably lumour grade can be considered as established. With regard to the more recenty developed prognostic factors this can only be stated for p53 and probably also microvessel density.

In Chapter II the prognostic value of the immunohistochemical pS2 determination is described. Although in pS2-negative tumours there was a trend for less locoregional relapse, the prognostic value of immunohistochemical $p 2$ determinattion could not be demonstrated neither for disease-free survival nor for overall survival. This is in line with the literature where no other study using this immunohistochemical method has found prognostic significance for the pS2 status of the tumour, at least in multivariate analysis. On the contrary several studies using the more laborious cytosolic assay have demonstrated better disease-free and/or overall survival in multivariate analysis. Probably with both methods different epitopes of the protein are measured. Furthermone, in our sludy $\mathrm{p} S 2$ was 
the most important factor for post-relapse survival in a multivariate analysis including axillary lymph node status, ER, PR, ploidy and $S$-phase fraction. This suggests that $\mathrm{p} S 2$ is a predictive factor for response to systemic therapy, although we were not able to formally address this question in our study. Because there are undications that $\mathrm{pS2}$ expression reflects the functional status of ER and is also involved in growth regulation, the $\mathrm{p} \$ 2$ status could have predictive value both for hormonal therapy and chemotherapy. In two other studies the predictive value of the pS2 status has been demonstrated for chemotherapy as well as for hormonal therapy. Further prospective studies are needed to investigate if the immunohistochemical pS2 status can be used to predict the response to systemic therapy.

In Chapter III a study on the possible use of the adhesion molecule CD44v6 as a prognostic factor is reported. Although the first study on this subject showed CD44v6 to be an independent prognostic factor, we could not confirm this in a much larger study with longer follow-up. Several other studies have also been unable to demonstrate the value of CD44v6 as a prognostic factor at least in multivariate analysis. It can, therefore, be concluded that the CD44v6 expression has no prognostic value in primary breast cancer. Such prognostic value seems also unlikely on biological grounds because CD $44 \mathrm{v} 6$ is often expressed in normal tissues including normal breast tissue. More studies are, however, needed to further elucidate the role of CD44 isoforms in the progression of cancer.

In Chapter IV it is demonstrated that the MIB-I labelling index is an independent prognostic factor for disease-free survival. This is true when a cut-off at the median value of $7 \%$ is used and also when MIB-1 is analysed as a continuous variable. Several other studies have shown that MIB-1 or Ki-67 are important prognositic factors in multivariate analysis for patients with primary breast cancer. There are other methods of measuring the proliferative activity of a tumour, such as the assessment of the $S$-phase fraction, thymidine-labelling index and mitotic index. These methods have been investigated in several studies and all of them have been found to have prognostic value sometimes in multivariate analysis. In our patients $S$-phase fraction only had an effect with respect to prognosis in univariate analysis. Only a few studies have directly compared different methods of measuring the proliferative acivity of a primary breast tumour. We observed a very weak association between $\mathrm{MIB}-1$ labelling index and the $S$-phase fraction. Several other authors have reported a higher association between $S$-phase fraction and MIB-1 or Ki-67. Furthermore, in our patients in multivariate analysis MIB- 1 labelling index but not $S$-phase fraction was a prognostic factor. The contrary has, however, also been reported. Most of these differences are probably explained by different methodologies. For routine clinical practice immunohistochemical methods 
seem most suitable. Because several studies have demonstrated the independent prognostic significance of Ki-67 and MIB-1, prospective studies with these antibodies are needed in which there should be consensus on the methodology.

In Chapter $V$ the proto-oncogene bcl-2 and the tumour suppressor gene $p 53$ were investigated with respect to their prognostic role in primary breast cancer. At the end of the whole follow-up period bcl-2 expression had no influence on diseasefree or overall survival. This seems at variance with most of the literature since in several studies it has been found that bcl-2 expression, at least in univariate analysis, is associated with better disease-free and/or overall survival. These differences can be explained by the length of the follow-up period, which was shorter in most studies. This suggests that bcl-2 expression is a time-dependent prognostic factor.

In our patients p53-positivity was associated with worse overall survival for the whole group of patients and the node-negative subgroup. In multivariate analysis p53 expression was also associated with decreased overall survival. With respect to disease-free survival there was a trend for better disease-free survival in p53 negative patients, but this did not reach statistical significance. These results correspond with those reported in the literature, but as has been stated in a review the prognostic effect of p53 is probably smal1. The fact that in our study p53 expression was correlated with poor post-relapse survival in multivariate analysis suggests that p53 expression could be predictive of the response to systemic therapy in patients with breast cancer. This is in line with the few data in the literature on the predictive value of $\mathrm{p} 53$ expression.

Of interest are the findings in bcl-2/p53 subgroups. In the bol-2 positive subgroup there was a large difference between p53 negative and p53 positive patients with respect to disease-free survival ( 77 vs $53 \% 5$-year survival) and overall survival ( 86 vs $59 \% 5$-year survival). In the bcl-2-negative subgroup, however, p53 status did not essentially influence disease-free or overall survival. Generally comparable tendencies were found in node-negative and node-positive patients. For post-relapse survival bcl-2 positive/p53 negative patients clearly had a better prognosis than the other 3 subgroups. More studies on these subgroups are needed and an explanation for this phenomenon, if it is confirmed, is not easy to give. Because bcl-2 expression in breast cancer is probably related to slower growth, it could be speculated that in bcl-2 positive breast tumours p53 status is important for the prognosis of the patient but not necessarily related to apoptosis. If on the other hand loss of bcl-2 expression is correlated with faster growth of breast cancer, it is conceivable that $\mathrm{p} 53$ no longer plays a role. 
In Chapter VI the resulis of counting microvessel density with ani-CD34 and antifVIII-RAg in the same patients are described. We were not able to confirm the results as mentioned in most of the literature, stating that microvessel density is an independent prognostic factor in primary breast cancer. Although in our patients a higher microvessel density as determined by anti-CD34 was associated with an increasing risk of relapse when analysed as a continuous variable, no single cut-off could be found that lead to a significant difference in disease-free survival. Microvessel density as determined by anti-fVIII-RAg showed no influence on both overall and disease-free survival. Several other investigators were also unable to demonstrate an (independent) prognostic value for microvessel density. This has resulted in active discussions in the literature. From these discussions it can be concluded that determining the microvessel density is technically difficult with several subjective aspects. The present method of microvessel counting, therefore, seems unsuitable for use in routine practice for patients with cancer.

Furthermore, in our patients age above 69 years was correlated with a lower microvessel density. This confirms the findings in two other studies. Assuming that microvessel density despite methodological problems is a prognostic factor, this suggests that older age is associated with a better prognosis in primary breast cancer.

In conclusion, with respect to all investigated prognostic variables, MBB-1 labelling index proved to be an independent prognostic factor for disease-free survival and p53 expression for overall survival. This supports much of what is found in the literature, however with a substantially longer follow-up than what has mostly been reported in other studies. In line with the literature none of the more recently developed factors studied in this thesis can be used to make treatment decisions in individual patients. Moreover about 20 years of research on these newer prognostic lactors in primary breast cancer has not lead to much progress in this subject. Improvement on this subject will only be possible when more uniform methods are used in prospective studies. It seems, however, unlikely at this moment that any single prognostic factor can be used in the future to decide which individual patient can benetit from (adjuvant) systemic therapy.

It could be more fruitful to use these newer factors to tailor adjuvant therapy for an individual patient. The fact that in our patients both pS2 and p53 had independent prognostic vallue for post-relapse survival in multivariate analyses, suggests that these factors can be used to predict response to systemic therapy. There is not much literature on this subject, but several studies now lend support to the idea that these newer factors better can be used as predictive than as prognostic factors. More studies on this subject, preferably prospective in character and with uniform methodologies are needed.

Further it can be speculated that molecular-biological merhods investigating specific 
genetic alterations give better prognostic information. Although at present most techniques used to screen or detect genetic alterations are laborious and costly, it might be anticipated, that for example with the development of DNA chip technology, genetic screening will become more generally available and can be used for prognostication. 


\section{Chapter VIII}

\section{Samenvatting en algemene discussie}




\section{Samenvatting en algemene discussie}

Borstkanker is de meest voorkomende maligniteit bij vrouwen in Nederland. De diagnose wordt per jaar bij meer dan 10.000 nieuwe patiënten gesteld. Ondanks een stijgende incidentie is de mortaliteit de laatste jaren ongeveer stabiel gebleven. Deze verbetering in de prognose is het meest waarschijnlijk te verklaren door twee factoren: ten eerste worden tumoren gediagnostiseerd in een gunstiger stadium, en ten tweede heeft adjuvante systemische behandeling met hormonen, chemotherapie, of een combinatie van beide, geresulteerd in betere ziektevrije en totale overleving. Echter, zeker niet alle patiënten met een primair mammacarcinoom hebben profijt van adjuvante systemische therapie. Historisch gezien werden alleen patiènten met okselkliermetastasen behandeld met adjuvante chemotherapie. Recent is er een toenemende tendens om patiënten zonder okselkliermetastasen met ongunstige prognostische factoren ook te behandelen. Er blijft onzekerheid bestaan welke de meest belangrijke prognostische factoren zijn. Het is noodzakelijk factoren te definiëren die de prognose van individuele patiënten bepalen. Op die manier kunnen patiënten met een hoge kans op curatie na loco-regionale therapie allén de bijwerkingen van systemische therapie bespaard worden, terwijl patiënten met een hoge kans op recidief of metastasen een individueel aangepaste therapie kunnen krijgen. Vooral de laatste 20 jaar zijn vele prognostische factoren onderzocht bij het primaire mammacarcinoom. Wij hebben de waarde onderzocht van diverse, meer recent ontwikkelde prognostische factoren, met behulp van immuunhistochemische methoden in een groep van 349 patiënten met primair mammacarcinoom uit één ziekenhuis, die zoveel mogelijk uniform behandeld zijn en met een mediane follow-up van meer dan 10 jaar.

In Hoofdstuk [ wordt een overzicht gegeven van de literatuur over prognostische factoren. In honderden studies zijn tienlallen prognostische factoren onderzocht. voornamelijk retrospectief met relatief weinig patienten en in het algemeen een korte follow-up.

Uit de literatuur hebben wij geconcludeerd dat slechts meer traditionele prognostische factoren, zoals de okselklierstatus, de grootte van de primaire tumor. proliferatieve activiteit, en waarschijnlijk de tumorgraad, beschouwd kunnen worden als gevestigde prognostische factoren.

M.b.t. de meer recent ontwikkelde prognostische factoren kan dit slechts gesteld worden voor 533 en warschijnlijk ook voor microvaatdichtheid.

In Hoofdstuk II wordt de prognostische waarde van de immuunhistochemische pS2 bepaling beschreven. Hoewel in $\mathrm{pS2}$-negatieve tumoren er een trend was voor minder locoregionale relapse, kon de prognostische waarde van immuunhistochemische pS2 bepaling niet worden aangetoond, noch voor ziektevrije overleving. 
noch voor tolate overleving. Dit komt overeen met wat in de literatuur wordt gesteld, waarbij geen enkele andere studie, die de immuunhistochemische methode heeft gebruikt, een progmostische waarde heeft aangetoond voor de pS2 status van de tumor, althans in multivariate analyse. Daarentegen hebben diverse studies, die de meer arbeidsintensieve cytosol-assay hebben gebruikt, een betere ziektevrije en totale overleving aangetoond in multivariate analyse. Het meest waarschijnlijk worden met beide methoden verschillende epitopen van het eiwit gemeten.

Verder was in onze studie pS2 de meest belangrijke factor voor de overleving na relapse in een multivariate analyse met axillaire lymfklierstatus, oestrogeenreceptor, progesteronreceptor, ploidie-status en S-fase fractie. Dit suggereert dat pS2 meer een predictieve factor is voor de response op systemische therapie, alhoewel wij niet in staat waren deze vraag in onze studie formeel te beantwoorden. Omdat er aanwijzingen zijn dat de $p S 2$ expressie de functionele status van de oestrogeenreceptor weerspiegelt, maar ook dat pS2 betrokken is bij de groeiregulatie, zou de pS2-status predictieve waarde kunnen hebben, zowel met betrekking tot hormonale therapie als chemotherapie.

In twee andere studies werd de predictieve warde van de pS2-status aangetoond voor chemotherapie en hormonale therapie. Verdere prospectieve studies zijn nodig on te onderzoeken of de immuunhistochemische pS2-status kan worden gebruikt on de response op systemische therapie te voorspellen.

In Hoofdstuk 1 II wordt een studie beschreven betreffende het mogelijk gebruik van het adhesiemolecuul CD44v6 als een prognostische factor.

Hoewel de eerste studie betreffende dit adhesiemolecuul aantoonde dat CD44v6 een onathankelijk prognostische factor is, konden wij dit in een veel grotere studie, met langere follow-up, niet bevestigen. Diverse andere kleinere studies konden ook de witarde wan CD44v6 als een prognostische factor niet aantonen, althans in multivariate analyse. Daarom kan worden geconcludeerd dat de CD44v6-expressie geen prognostische waarde heeft bij het primaire mammacarcinoom. Een dergelijke prognostische waarde lijkt op biologische gronden ook minder waarschijnlijk, ondat CD44v6 valak tot expressie komt in normaal weefsel, inclusief normaal mammaweetsel. Meer onderzoek is echter nodig om de rol van CD44 isovormen bij de progressie van maligniteiten te verhelderen.

In Hooldstuk IV wordt aangetoond dat de MIB- I labeling index als een maat voor de proliferatic een onafhankelijke prognostische factor is met betrekking tot ziektevrije overleving. Dit is zowel waar bij een cut-off punt bij de mediane watarde van $7 \%$, als wanneer MIB-1 wordt geanalyseerd als een continue variabele. Diverse andere studies hebben aangetoond dat MIB-I of Ki67 belangrijke prognostische factoren zijn in multivariate analyse voor patiënten met een primair mammacarcinoom. Er zijn echter ook andere methoden om de proliferatieve 
activiteit van de tumor te meten, zoals het meten van de $S$-fase fractie, de thymidine labeling index en de mitotische index. Deze methoden zijn ook in diverse studies onderzocht en van alle is prognostische waarde aangetoond, soms in multivariate analyse. $\mathrm{Bij}$ onze patiënten had $\mathrm{S}$-fase fractie alleen waarde met betrekking tot prognose in univariate analyse.

Slechts weinig studies hebben verschillende methoden om de proliferatieve activiteit van de primaire mammatumor te meten direct vergeleken. Wij konden slechis een zeer zwakke associatie tussen MIB-1 labeling index en S-fase fractie aantonen. Diverse andere studies hebben een hogere associatie tussen S-fase fractie en MIB-I of Ki67 gevonden.

Verder was bij onze patiënten met behulp van multivariate analyse wel de MIB-1 labelingsindex, doch niet de $S$-fase fractie, een prognostische facior. Het tegenovergestelde is echter ook beschreven. De meeste van deze verschillen kumen waarschijnlijk worden verklaard door verschil in de methodologie. In de normale routinepraktijk lijken immuunhistochemische methoden het meest geschikt. Omdat diverse studies de onafhankelijke prognostische waarde van Ki67 en MIB-1 hebben aangetoond, zijn prospectieve studies met deze antilichamen noodzakelijk, waarbij er consensus dient te zijn beireffende de methodologie.

In Hoofdstuk $V$ werden het proto-oncogen bcl-2 en het tumorsuppressorgen p53 onderzocht met betrekking tot de prognostische rol bij het primair mammacarcinoom. Na de gehele follow-up periode had bcl-2 expressie geen invloed op de ziektevrije totale overleving. Dit lijkt afwijkend van het merendeel van de literatuur, omdat in diverse studies is gevonden dat de bcl-2 expressie op z'n minst in univariate analyse is geassocieerd met een betere ziektevrije en/of totale overleving. Deze verschillen kunnen waarschijnlijk worden verklaard door de lengte van de follow-up periode, die in de meeste studies beduidend korter is. Dit suggereert dat de bcl-2 expressie een tijdsafhankelijke prognostische factor is.

In onze patiënten was p53-positiviteit geassocieerd met een slechtere totale overleving voor de hele groep patiënten en de klier-negatieve subgrocp. Ook in multivariate analyse was p53-expressie geassocieerd met een verminderde rotale overleving. Wat betreft de ziektevrije overleving was er een trend voor een betere ziektevrije overleving bij p53-negatieve patiënten, doch dit verschil was niet statistisch significant. Deze resultaten komen overeen met wat in de literatuur wordt gemeld, maar zoals in een review werd gesteld is het prognosisch effect van p53 waarschijnlijk klein.

Het feit dat in onze studie p53 expressie was gecorreleerd met een slechte overleving na relapse, ook in multivariate analyse, suggereert dat p53-expressie de response op systemische therapie in patiënten met mammacarcinoom kan voorspellen. De overigens beperkte gegevens in de literatur betreffende de predictieve waarde van p53-expressie ondersteunen dit. 
Belangrijk zijn verder de bevindingen in de bcl-2/p53 subgroepen. In de bcl-2positieve subgroep was er een groot verschil tussen p53-negatieve en p53-positieve patiënten wat betreft de ziektewrije overleving ( 77 vs $53 \% 5$-jaars overleving) en totale overleving ( 86 vs $59 \%$-jaars overleving). In de bcl-2-negatieve subgroep echter had de p53-status geen noemenswaardige invloed op de ziektevrije of totale overleving. In het algemeen werden in de subgroepen van klier-positieve en kliernegatieve patiënten vergelijkbare tendensen gevonden. Ook wat betreft de overleving na relapse hadden bcl-2-positieve/p53-negatieve patiënten duidelijk een betere prognose dan de drie andere subgroepen.

Meer studies betreffende deze subgroepen zijn nodig en een verklaring voor dit fenomeen, indien het wordt bevestigd, is niet gemakkelijk te geven. Ondat bcl-2expressie bij het mammacarcinoom waarschijnlijk gekoppeld is aan een langzamere groei, kan worden gespeculeerd dat bij bcl-2-positieve mammacarcinomen de p53status belangrijk is voor de prognose van de patiënt, hoewel dit niet noodzakelijkerwijze gerelateerd hoeft te zijn aan apoptose. Indien anderzijds verlies van bcl-2-expressie is gerelateerd met snellere groei van het mammacarcinoom, is het denkbaar dat de p53-status geen rol meer speelt.

In Hoofdstuk VI worden de resultaten beschreven van het bepalen van de microvaatdichtheid met anti-CD34 en anti-factor VIIIRAg in dezelfde groep patiënten. Wij waren niet in staat de resultaten, zoals vermeld in het merendeel van de literatuur, te bevestigen, waarin gesteld wordt dat microvaatdichtheid een onafhankelijke prognostische factor is bij het primair mammacarcinoom.

Hoewel bij onze patiënten een hogere microvaatdichtheid, zoals vastgesteld met anti-CD34, geassocieerd was met een toenemend risico op een relapse bij analyse als een continue variabele, kon er geen cut-off waarde worden vastgesteld, die atanleiding gaf tot een significant verschil in ziektevrije overleving. Microvatdichtheid, zoals bepaald door anti-factor VIIIRAg, had geen invloed op zowel de zieklevrije als de totale overleving. Diverse andere onderzoekers waren ook niet in staat om de (onafhankelijke) prognostische waarde van microvaatdichtheid aan te tonen. Dit heeft geleid tot levendige discussies in de literatuur. Uil deze discussies kan worden geconcludeerd dat het meten wan de microvaatdichiheid een technisch moeilijke methode is met diverse subjectieve aspecten. Daarom lijkt de huidige methode van het bepalen van de microvatdichtheid nauwelijks bruikbaar voor gebruik in de routinepraktijk voor patiënten met een maligniteit.

Verder was bij onze patiënten leeftijd boven de 69 jaar gecorreleerd met een lagere microvaatdichtheid. Dit bevestigt de bevindingen in twee andere studies. Indien men aanneemt dat microvaatdichtheid ondanks methodologische problemen toch een prognostische factor is, suggereert dit dat oudere leeftijd geassocieerd is met een betere prognose bij het primaire mammacarcinoom. 
Concluderend: kijkend naar alle onderzochte prognostische variabelen bleek de MIB-I labeling index een onafhankelijke prognostische factor te zijn voor ziektevrije overleving en de p53-expressie voor totale overleving. Dit steunt veel van wat is gevonden in de literatuur, echter met een duidelijk langere follow-up dan in de meeste andere studies wordt gemeld. Echter in overeenstemning met de literatuur kan geen enkele van de meer recent ontwikkelde factoren, zoals in dit proefschrift bestudeerd, gebruikt worden voor beslissingen bij de behandeling van een individuele patiënt. Meer dan 20 jaar research met deze nieuwere prognostische factoren bij het primaire mammacarcinoom, heeft zelfs niet geleid tot veel vooruitgang op dit gebied. Een verbetering dienaangaande is alleen mogelijk wanneer meer uniforme methoden worden gebruikt in prospectieve studies. Het lijkt echter op dit moment onwaarschijnlijk dat én enkele prognostische factor in de toekomst gebruikt kan worden om te beslissen welke individuele patiënt profijt kan hebben van (adjuvante) systemische therapie.

Het is waarschijnlijk nuttiger deze nieuwere factoren te gebruiken om systemische therapie aan een individuele patiënt "op maat" te geven. Het feit dat bij onze patiënten zowel pS2 als p53 onathankelijke prognostische waarde had in multivariate analyse voor de overleving na relapse, suggereert dat deze factoren kumen worden gebruikt voor het voorspellen van een response op systemische therapie.

Er is niet veel literatuur betreffende dit onderwerp, maar diverse studies zijn op dit moment niet in tegenspraak met de stelling, dat nieuwere factoren beter kunnen worden gebruikt als predictieve dan als prognostische factoren. Meer studies dienaangaande zijn nodig, bij voorkeur prospectief en met uniforme methodologie. Verder kan worden gespeculeerd dat moleculair-biologische methoden, die specifieke genetische veranderingen onderzoeken, betere prognostische informatie geven. Hoewel op dit moment de meeste technieken on genetische veranderingen te ontdekken kostbaar en arbeidsintensief zijn, is het denkbaar dat bv. met de ontwikkeling van DNA-chip technologie, genetische screening meer algemeen toepasbaar wordt en gebruikt kan worden als prognostische factor. 
Dankwoord 


\section{Dankwoord}

Aan de totstandkoming van dit proefschrift hebben velen direct of indirect een bijdrage geleverd. Allereerst wil ik al diegenen danken, die behulpzaam waren bij het verzamelen van de klinische gegevens van de patienten, te weten de medewerkers wan het lntegraal Kankercentrum Limburg, met name dr Leo Schouten en de medewerkers van de polikliniek Chirurgie en van het Medisch Archief van het azM. De secretaresses van de afdeling Pathologie hebben mij via hun computer de gelegenheid gegeven te zoeken naar data uit PALGA en Elly Kerssemeekers heeft mij zelfs begeleid naar de stoffige kelders van het azM om gegevens uit de tijd vór PALGA te vinden. De pathologen Prof dr Mat Daemen, dr Adriaan de Brume, dr Erik Thunnissen en Ton Vermeulen waren behulpzaam bij het beoordelen van coupes.

Susan Joosten-Achjanie heeft gedurende een aantal jaren veel werk verricht op het Laboratorium Oncologie. Zonder haar was dit proefschrift niet tot stand gekomen en ik ben haar daarvoor dan ook zeer dankbaar. Ook Hans Ader, Jeroen Buijsen en Marielle Das hebben op het laboratorium hun bijdrage geleverd.

Lex Volovics van de afdeling Medische Statistiek heeft samen met mij vele uren achter de computer gezeten. Zonder zijn hulp waren alle gegevens nooit op statistisch verantwoorde wijze bewerkt.

Grote dank ben ik verschuldigd aan Diana Gorissen naar met name aan Mieke Haemers, die met eindeloos geduld de vele versies van alle artikelen op papier hebben gezet.

Verder will ik hier met name Tiny Wouters noemen, die op deskundige wijze ervoor heeft gezorgd dat het manuscript drukklaat werd gemaakt.

Verder wil ik hier de leden van de Werkgroep Haematologie-Oncologie Amemarie ten Haaft, dr Karly Hamulyàk, dr Lizzy van Pampus, dr Pierre Hupperets, Roy Lalisang en dr Ruud van Rijswijk danken voor hun steun, waarbij de drie laatstgenoemden gedurende enige tijd zonder morren een deel van mijn patiëntgebonden werkzaamheden hebben overgenomen.

Verder will ik hier mijn beide promotoren, Prof dr Harry Hillen en Prof dr Jan-Willem Arends bedanken voor hun deskundige begeleiding en blijvende steun bij de totstandkoming van dit proefschrift, ook in tijden dat er weinig schot in zat. Veel dank ben ik ook verschuldigd aan mijn co-promotor dr Harry Schouten, die in feite de grote initiator en stimulator van dit proefschrift is.

Ook wil ik hier mijn kinderen Mark, Lenno en Rodi noemen. Teweel hebben zij hun vader moeten missen omdat hij weer geen tijd had. Misschien kunnen we na I oktober toch beginnen met de modeltrein en met andere leuke dingen.

Tenslotte wil ik hier mijn lieve vrouw Carla bedanken, die altijd de spil van ons gezin was en zonder al te veel mopperen mijn vele avonden werken heeft geaccepteerd. Ook zonder halar was dit proefschrift zeker niet mogelijk geweest. 
Curriculum Vitae 


\section{Curriculum Vitae}

De auteur van dit proefschrift werd geboren op 30 mei 1954 te Breda. Na het behalen van het gymnastium-fo diploma aan het Bisschoppelijk College te Sittard, studeerde hij van 1972 tot 1979 geneeskunde aan de Katholieke Universiteit Nijmegen. Na het vervullen van de militaire dienstplicht volgde hij in de periode 1981 tot 1986 de opleiding interne geneeskunde in het Gemeenteziekenhuis (nu: Merwedeziekenhuis) in Dordrecht (opleider: dr BA de Planque) en het de Weverziekenhuis (nu: Atrium Medisch Centrum) in Heerlen (opleider: dr FTh Lustermans). Vanaf begin 1986 was hij als internist werkzaam in de Daniël den Hoed Kliniek in Rotterdam bij dr G Stoter. In 1988 en 1989 was hij KWFfellow, waarbij ook 1 jaar werd gewerkt op een laboratorium van her National Cancer Institute in Frederick, Maryland, Verenigde Staten. Sinds 1 februari 1992 is hij als internist werbonden aan de Werkgroep Haematologie-Oncologie van de Vakgroep Interne Geneeskunde (hoofd: Prof dr HFP Hillen) van het Academisch Ziekenhuis Maastricht. 